PNNL-19015

WTP-RPT-206, Rev 0

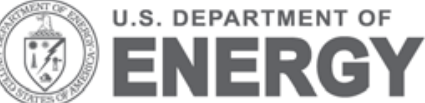

Prepared for the U.S. Department of Energy

under Contract DE-AC05-76RL01830

\title{
Effect of Antifoam Agent on Oxidative Leaching of Hanford Tank Sludge Simulant
}

BM Rapko

SA Jones
GJ Lumetta

RA Peterson

February 2010

Pacific Northwest

NATIONAL LABORATORY

Proudly Operated by Battelle Since 1965 


\title{
DISCLAIMER
}

This report was prepared as an account of work sponsored by an agency of the United States Government. Neither the United States Government nor any agency thereof, nor Battelle Memorial Institute, nor any of their employees, makes any warranty, express or implied, or assumes any legal liability or responsibility for the accuracy, completeness, or usefulness of any information, apparatus, product, or process disclosed, or represents that its use would not infringe privately owned rights. Reference herein to any specific commercial product, process, or service by trade name, trademark, manufacturer, or otherwise does not necessarily constitute or imply its endorsement, recommendation, or favoring by the United States Government or any agency thereof, or Battelle Memorial Institute. The views and opinions of authors expressed herein do not necessarily state or reflect those of the United States Government or any agency thereof.

\author{
PACIFIC NORTHWEST NATIONAL LABORATORY \\ operated by \\ BATTELLE \\ for the \\ UNITED STATES DEPARTMENT OF ENERGY \\ under Contract DE-ACO5-76RL01830
}

Printed in the United States of America
Available to DOE and DOE contractors from the
Office of Scientific and Technical Information,
P.O. Box 62, Oak Ridge, TN 37831-0062;
ph: (865) 576-8401
fax: (865) 5765728
email: reports@adonis.osti.gov

\footnotetext{
Available to the public from the National Technical Information Service, U.S. Department of Commerce, 5285 Port Royal Rd., Springfield, VA 22161 ph: (800) 553-6847 fax: (703) 605-6900

email: orders@nits.fedworld.gov online ordering: http://www.ntis.gov/ordering.htm
} 


\title{
Effect of Antifoam Agent on Oxidative Leaching of Hanford Tank Sludge Simulant
}

\author{
BM Rapko \\ GJ Lumetta \\ SA Jones \\ RA Peterson
}

February 2010

Test Specification: 24590-PTF-TSP-RT-06-002, Rev. 0

Test Plan: TP-RPP-WTP-456, Rev. 0.2

Test Exception: 24590-WTP-TEF-RT-08-00012 Rev. 1

R\&T focus area: Pretreatment

Test scoping statement(s): 24590-WTP-PL-RT-01-002, Appendix C, B-89

Pacific Northwest National Laboratory

Richland, Washington 99352 


\section{Completeness of Testing}

This report describes the results of work and testing specified by Test Plan TP-RPP-WTP-456, Rev 0.2, and ICN-TP-RPP-WTP-456, Rev 0.2. The work and any associated testing followed the quality assurance requirements outlined in the Test Specification/Plan. The descriptions provided in this test report are an accurate account of both the conduct of the work and the data collected. Test Plan results are reported. Also reported are any unusual or anomalous occurrences that are different from expected results. The test results and this report have been reviewed and verified.

Approved:

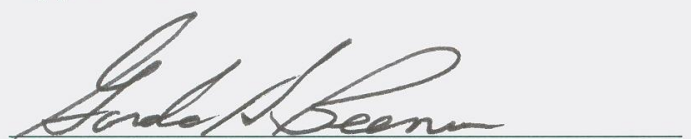

Gordon H. Beeman, Manager RPP-WTP Support Program

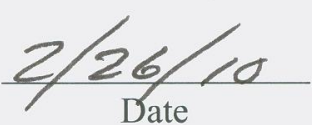




\section{Contents}

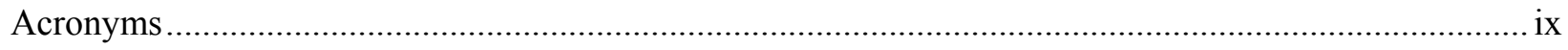

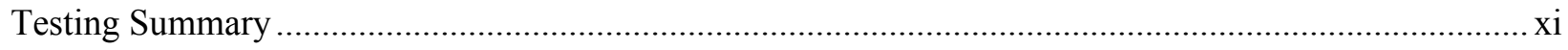

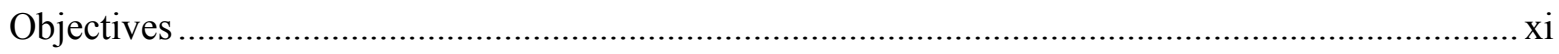

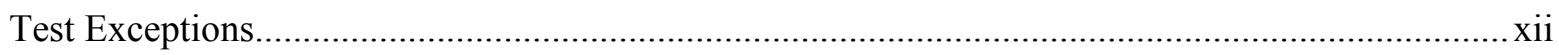

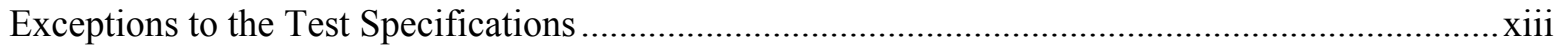

Results and Performance Against Success Criteria .......................................................................

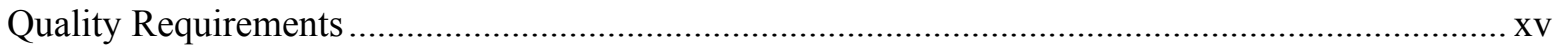

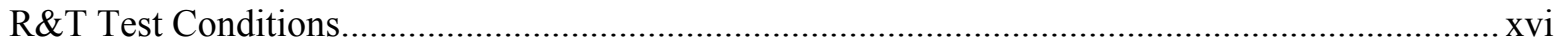

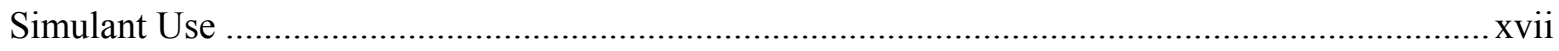

Discrepancies and Follow-On Tests .........................................................................................

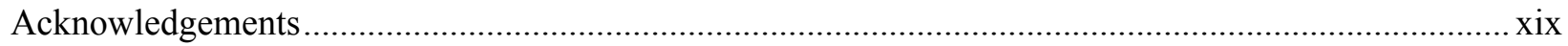

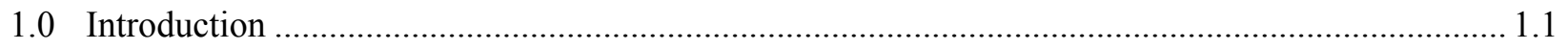

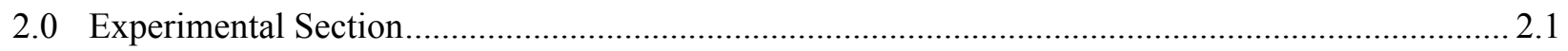

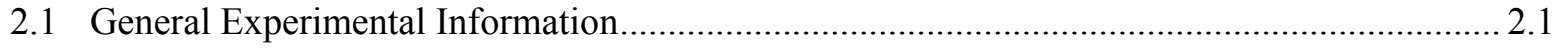

2.2 Preparation of Radioactive Simulant............................................................................. 2.1

2.2.1 Preparation of the Radioactive Chromium Leaching Simulant ................................... 2.2

2.2.2 Division of the Radioactive Simulant for Oxidative Leaching Experiments ................ 2.3

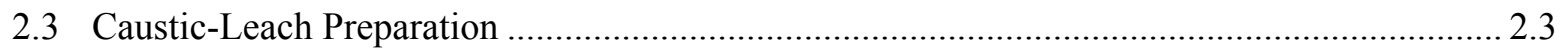

2.4 Test Sample Preparation and Characterization ................................................................. 2.4

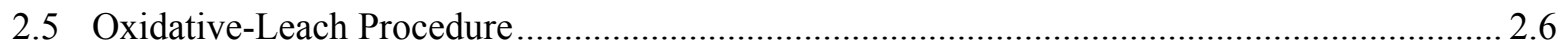

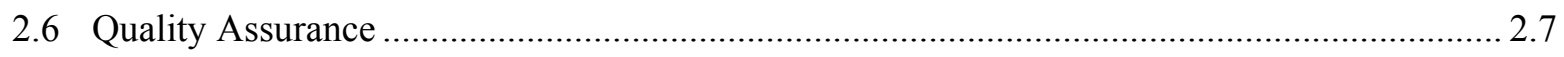

2.7 Conduct of Experimental and Analytical Work ............................................................... 2.7

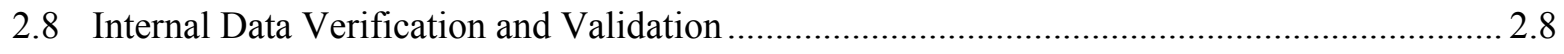

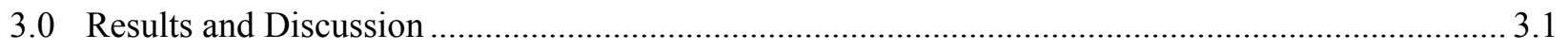

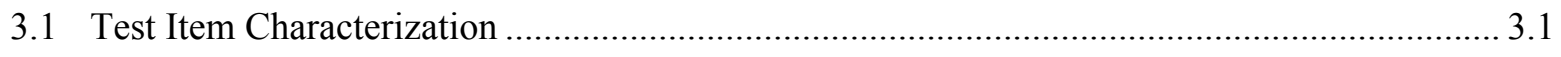

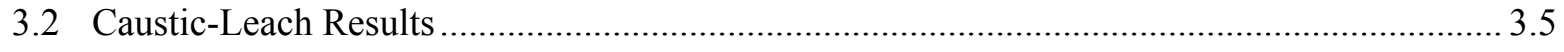

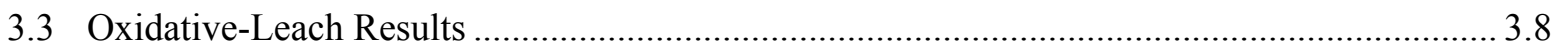

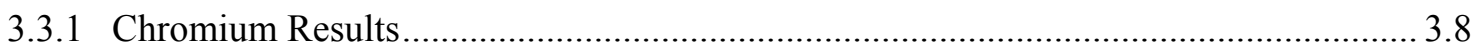

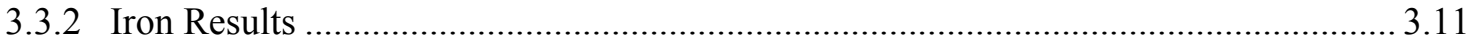

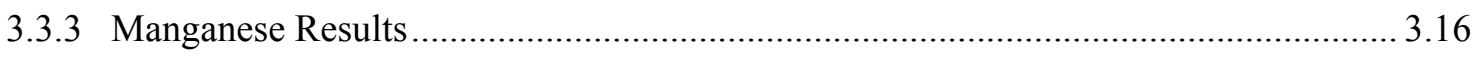

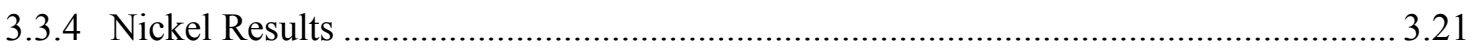

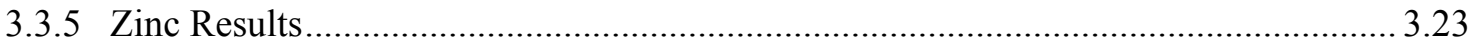

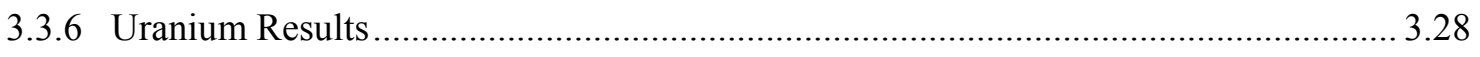

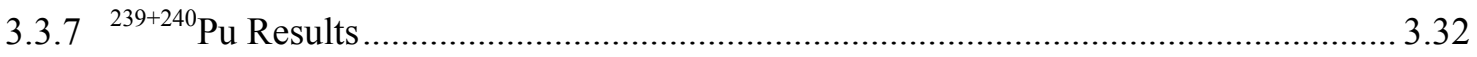

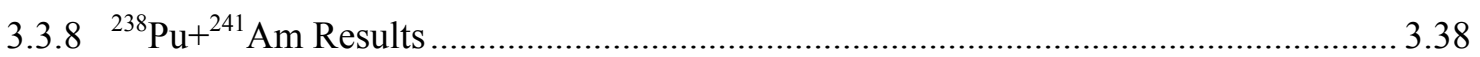


3.3.9 Combined Results Comparisons.

3.44

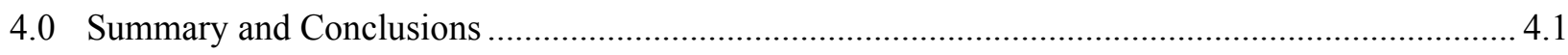

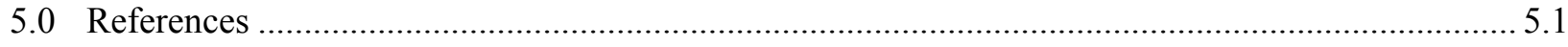

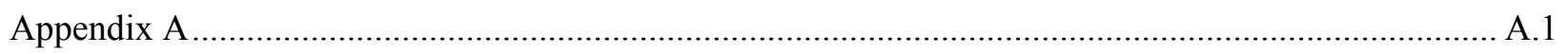

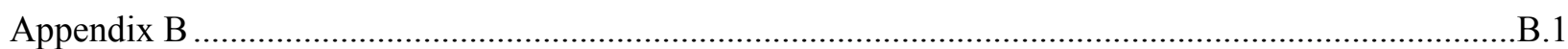




\section{Figures}

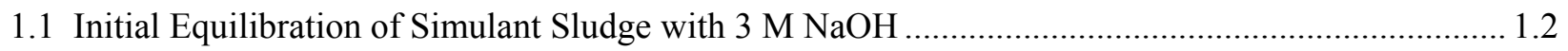

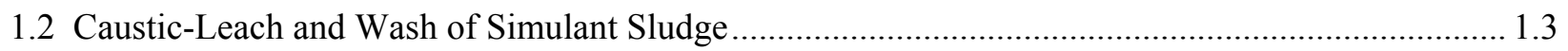

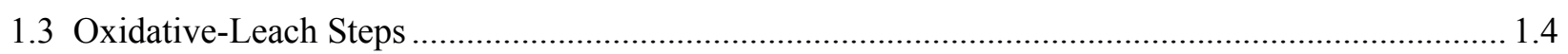

3.1 Some of the Test Items Equilibrated with $3 \mathrm{M} \mathrm{NaOH}$ Before Heating for Caustic-Leach................ 3.5

3.2 Impact of AFA Concentration on Key Elements During Caustic Leaching .................................... 3.7

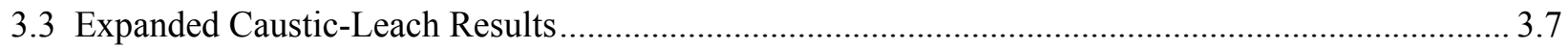

3.4 Chromium Removed from Simulated Tank Sludge by Oxidative Leaching with Permanganate....... 3.9

3.5 Quantity of Chromium in the Solids Before Oxidative Leaching (Initial) and After Oxidative

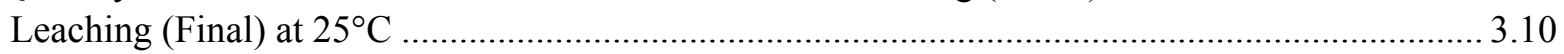

3.6 Quantity of Chromium in the Solids Before Oxidative Leaching (Initial) and After Oxidative

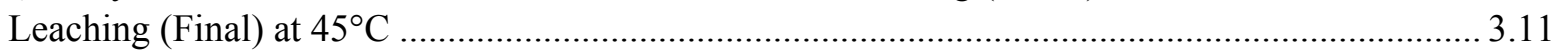

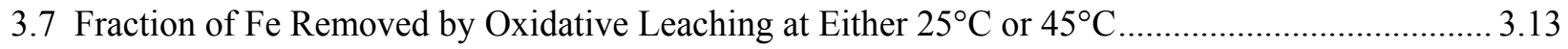

3.8 Quantity of Iron in the Solids Before Oxidative Leaching (Initial) and After Oxidative Leaching (Final) at $25^{\circ} \mathrm{C}$

3.9 Quantity of Iron in the Solids Before Oxidative Leaching (Initial) and After Oxidative Leaching (Final) at $45^{\circ} \mathrm{C}$

3.10 Quantity of Manganese in the Solids Before Oxidative Leaching (Initial) and After Oxidative Leaching (Final) at $25^{\circ} \mathrm{C}$

3.11 Quantity of Manganese in the Solids Before Oxidative Leaching (Initial) and After Oxidative Leaching (Final) at $45^{\circ} \mathrm{C}$

3.12 Fraction of Nickel Removed from Simulated Tank Waste by Permanganate Oxidative Leaching 3.22

3.13 Fraction of $\mathrm{Zn}$ Removed by Oxidative Leaching at Either $25^{\circ} \mathrm{C}$ or $45^{\circ} \mathrm{C}$

3.14 Quantity of Zinc in the Solids Before Oxidative Leaching (Initial) and After Oxidative Leaching (Final) at $25^{\circ} \mathrm{C}$.

3.15 Quantity of Zinc in the Solids Before Oxidative Leaching (Initial) and After Oxidative Leaching (Final) at $45^{\circ} \mathrm{C}$.

3.16 Fraction of U Removed by Oxidative Leaching at Either $25^{\circ} \mathrm{C}$ or $45^{\circ} \mathrm{C}$.

3.17 Quantity of Uranium in the Solids Before Oxidative Leaching (Initial) and After Oxidative Leaching (Final) at $25^{\circ} \mathrm{C}$.

3.18 Quantity of Uranium in the Solids Before Oxidative Leaching (Initial) and After Oxidative Leaching (Final) at $45^{\circ} \mathrm{C}$

3.19 Fraction of ${ }^{239+240} \mathrm{Pu}$ Removed by Oxidative Leaching at Either $25^{\circ} \mathrm{C}$ or $45^{\circ} \mathrm{C}$

3.20 Quantity of ${ }^{239+240} \mathrm{Pu}$ in the Solids Before Oxidative Leaching (Initial) and After Oxidative Leaching (Final) at $25^{\circ} \mathrm{C}$

3.21 Quantity of ${ }^{239+240} \mathrm{Pu}$ in the Solids Before Oxidative Leaching (Initial) and After Oxidative Leaching (Final) at $45^{\circ} \mathrm{C}$. 
3.22 Fraction of ${ }^{238} \mathrm{Pu}+{ }^{241} \mathrm{Am}$ Removed by Oxidative Leaching at Either $25^{\circ} \mathrm{C}$ or $45^{\circ} \mathrm{C}$.

3.23 Quantity of ${ }^{238} \mathrm{Pu}+{ }^{241} \mathrm{Am}$ in the Solids Before Oxidative Leaching (Initial) and After Oxidative Leaching (Final) at $25^{\circ} \mathrm{C}$......

3.24 Quantity of ${ }^{238} \mathrm{Pu}+{ }^{241} \mathrm{Am}$ in the Solids Before Oxidative Leaching (Initial) and After Oxidative Leaching (Final) at $45^{\circ} \mathrm{C}$

3.25 Relationship Between ${ }^{239+240} \mathrm{Pu}$ and ${ }^{238} \mathrm{Pu}+{ }^{241} \mathrm{Am}$ Removal by Oxidative Leaching 


\section{Tables}

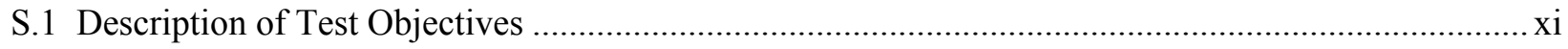

S.2 Exceptions to the Test Specifications and Their Justification ....................................................... xiii

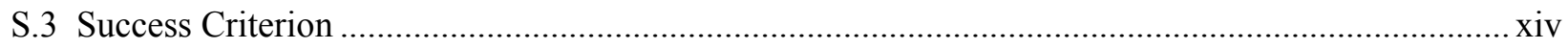

S.4 List of R\&T Test Conditions and Whether They Were Followed .................................................. xvi

1.1 Test Conditions for Radioactive Simulant Testing .................................................................... 1.1

2.1 Commercially-Procured Phases Used in the Simulant................................................................... 2.2

2.2 Initial Components Combined for the Radioactive Simulant ....................................................... 2.2

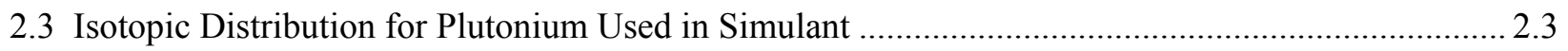

2.4 Caustic-Leach Volumes Used with Radioactive Simulant Testing ................................................ 2.4

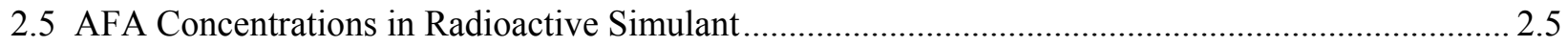

2.6 Quantities of Chromium and Manganese Present in Test Items at Beginning of Oxidative

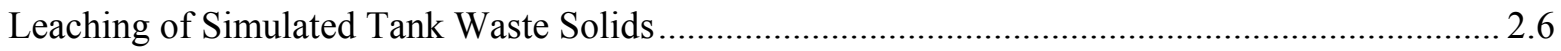

3.1 Measured Amounts of Key Components in the Radioactive Simulant Solids Equilibrated with $3 \mathrm{M} \mathrm{NaOH}$ Before Heating for Caustic Leaching............................................................... 3.1

3.2 Initial Amounts of Key Components in Equilibrated Leachate Solution Before Heating

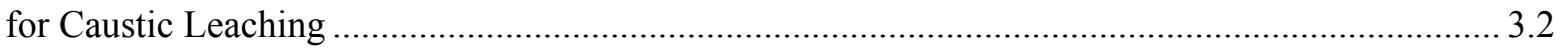

3.3 Statistical Analysis of Triplicate Test Items at Two AFA Concentration Levels in the Simulant...... 3.3

3.4 Anions, Hydroxide, Inorganic and Organic Carbon in Supernate Before Heating for

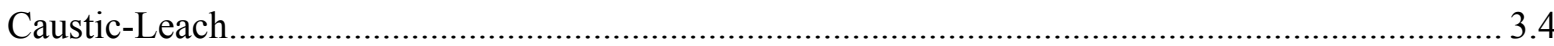

3.5 Inorganic and Organic Carbon in Solids Before Caustic-Leach ...................................................... 3.4

3.6 Amounts of Key Components in Caustic Leachate ...................................................................... 3.6

3.7 Chromium Removal from Simulated Tank Sludge by Oxidative Leaching .................................... 3.8

3.8 Summary of Cr Removal by Oxidative-Leach Tests .................................................................... 3.9

3.9 Iron Removal from Simulated Tank Sludge by Oxidative Leaching ............................................ 3.12

3.10 Summary of Fe Removal by Oxidative-Leach Tests .............................................................. 3.14

3.11 Amounts of Manganese Present During Testing .................................................................. 3.17

3.12 Manganese in Solids from Simulated Tank Sludge by Oxidative Leaching................................. 3.17

3.13 Summary of Mn Concentration by Oxidative-Leach Tests ......................................................... 3.18

3.14 Nickel Removal from Simulated Tank Sludge by Oxidative Leaching ....................................... 3.21

3.15 Zinc Removal from Simulated Tank Sludge by Oxidative Leaching .......................................... 3.23

3.16 Summary of Zn Removal by Oxidative-Leach Tests............................................................. 3.25

3.17 Uranium Removal from Simulated Tank Sludge by Oxidative Leaching ................................... 3.28

3.18 Summary of U Removal by Oxidative-Leach Tests ................................................................. 3.30

$3.19{ }^{239+240} \mathrm{Pu}$ Removal from Simulated Tank Sludge by Oxidative Leaching ..................................... 3.33

3.20 Summary of ${ }^{239+240} \mathrm{Pu}$ Removal by Oxidative-Leach Tests ...................................................... 3.35 
$3.21{ }^{238} \mathrm{Pu}+{ }^{241} \mathrm{Am}$ Removal from Simulated Tank Sludge by Oxidative Leaching .............................. 3.38

3.22 Summary of ${ }^{238} \mathrm{Pu}+{ }^{241} \mathrm{Am}$ Removal by Oxidative-Leach Tests .................................................... 3.40

3.23 Comparison of Analytical Results for Key Components on Duplicate Samples of

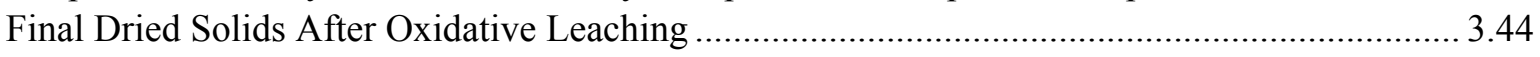

3.24 Amounts of Key Components in Final Washed and Dried Residual Solids Following Oxidative Leaching with Permanganate 3.45

3.25 Statistical Analysis of Triplicate Test Items at Two AFA Concentration Levels .......................... 3.46

4.1 Chromium Distribution Between Liquid and Solid for Each Phase of Testing ................................ 4.2

4.2 Summary of Cr Removal by Oxidative-Leach Tests .................................................................... 4.3 


\section{Acronyms}

AEA alpha energy analysis

AFA antifoam agent

ASO Analytical Support Operations

BNI Bechtel National Incorporated

CUF Cells Unit Filter

DI deionized (water)

DOE U.S. Department of Energy

HDI "How Do I...?"

IC ion chromatography

ICP inductively coupled plasma

LSC liquid scintillation counting

M\&TE measuring and test equipment

OES optical emission spectroscopy

PNNL Pacific Northwest National Laboratory

PNWD Battelle-Pacific Northwest Division

QA quality assurance

QAM Quality Assurance Manual

QAP Quality Assurance Plan

QARD Quality Assurance Requirements and Descriptions

QC quality control

RF resorcinol-formaldehyde

RPL Radiochemical Processing Laboratory

RPP River Protection Project

SOW statement of work

SP Support Project

TIC total inorganic carbon

TOC total organic carbon

TP Test Plan

WTP Hanford Tank Waste Treatment and Immobilization Plant

WTPSP Waste Treatment Plant Support Project 



\section{Testing Summary}

Previous studies sponsored by Bechtel National Inc. (BNI) have targeted optimizing the use of sodium permanganate for selectively oxidizing chromium from washed Hanford tank sludge (Rapko et al. 2004; Rapko et al. 2005). The need for the proposed additional testing of the chromium simulant containing antifoam agent (AFA) for leach behavior during oxidative leaching was identified as a result of evaluating AFA effectiveness during oxidative leaching (SCT-MORLE60-00-199-00002 Rev 00A). This report documents the results of those tests.

\section{Objectives}

Table S.1 describes the test objectives and whether the objectives were met.

Table S.1. Description of Test Objectives

\begin{tabular}{|c|c|c|}
\hline Test Objective & Objective Met (Y/N) & Discussion \\
\hline $\begin{array}{l}\text { Investigate the efficacy of defined } \\
\text { oxidant dosage through bench-scale } \\
\text { experimental testing with two actual } \\
\text { Hanford tank waste sludges. }\end{array}$ & Yes & Provided in report WTP-RPT-171, Rev 0. \\
\hline $\begin{array}{l}\text { Demonstrate the oxidative leaching } \\
\text { process in the laboratory using } \\
\text { actual waste at conditions that } \\
\text { represent the anticipated plant } \\
\text { flowsheet conditions for all } \\
\text { anticipated process systems. }\end{array}$ & Yes & Provided in report WTP-RPT-171, Rev 0. \\
\hline $\begin{array}{l}\text { Develop information on the fate of } \\
\text { Pu and neutron absorbers (B and Cd) } \\
\text { for both process design verification } \\
\text { and process criticality safety } \\
\text { assessment. Specifically, } \\
\text { information that will be obtained is } \\
\text { the concentration of Pu in the } \\
\text { oxidative leachate and the oxidation } \\
\text { state(s) of the Pu (using techniques } \\
\text { being developed in the current Pu } \\
\text { speciation determination activity). } \\
\text { Further, changes in the Pu oxidation } \\
\text { state will be monitored during the } \\
\text { nominal processing steps of the } \\
\text { leachate, and material balances will } \\
\text { be monitored to assess the potential } \\
\text { to precipitate Pu during any of the } \\
\text { steps before ion exchange. Finally, } \\
\text { the fate of Pu during ion exchange } \\
\text { (using spherical } \\
\text { resorcinol-formaldehyde) will be } \\
\text { determined using feed adjusted to }\end{array}$ & Yes & Provided in report WTP-RPT-171, Rev 0. \\
\hline
\end{tabular}


Table S.1. Description of Test Objectives

\begin{tabular}{|c|c|c|}
\hline Test Objective & Objective Met (Y/N) & Discussion \\
\hline \multicolumn{3}{|l|}{$\begin{array}{l}5 \mathrm{M} \mathrm{Na} \text { (through evaporative } \\
\text { concentration or dilution) and } \\
\text { elution with } 0.5 \mathrm{M} \mathrm{HNO}_{3} \text {. }\end{array}$} \\
\hline $\begin{array}{l}\text { Investigate the efficacy of defined } \\
\text { oxidant dosage through bench-scale } \\
\text { experimental testing with two actual } \\
\text { Hanford tank waste sludges. }\end{array}$ & Yes & Provided in report WTP-RPT-171, Rev 0. \\
\hline $\begin{array}{l}\text { Determine the effect of AFA on the } \\
\text { oxidative leaching efficiency for } \\
\text { chromium (as extent of chromium } \\
\text { oxidative leached), using the } \\
\text { radioactive simulant developed for } \\
\text { the oxidative leaching studies. A } \\
\text { radioactive simulant is required to } \\
\text { satisfy all the listed objectives. }\end{array}$ & Yes & $\begin{array}{l}\text { A radioactive simulant was prepared and used in } \\
\text { all tests. There was no apparent effect of the } \\
\text { AFA on oxidative leaching efficiency for } \\
\text { chromium as described in Results and Discussion, } \\
\text { Section } 3.2 \text {. }\end{array}$ \\
\hline $\begin{array}{l}\text { Determine the effects of AFA on } \\
\text { dissolution of Pu and other } \\
\text { criticality-related elements during } \\
\text { oxidative leaching, using the } \\
\text { radioactive simulant developed for } \\
\text { the oxidative leaching studies. }\end{array}$ & Yes & $\begin{array}{l}\text { Plutonium was included in the radioactive } \\
\text { simulant used for testing the AFA effect. There } \\
\text { was no apparent effect of AFA on Pu, Am, or U } \\
\text { during oxidative leaching. }\end{array}$ \\
\hline $\begin{array}{l}\text { Verify the results from the } \\
\text { radioactive simulant tests above with } \\
\text { a minimum of two actual waste tests } \\
\text { with the Group } 6 \text { S-Saltcake waste } \\
\text { solids. }\end{array}$ & No & $\begin{array}{l}\text { Since 1) addition of AFA did not affect the extent } \\
\text { of Pu dissolution from the simulant, and 2) the Pu } \\
\text { in the actual waste has generally been less } \\
\text { amenable to oxidation relative to the Pu in the } \\
\text { simulant, a decision was made by BNI not to test } \\
\text { with the actual waste. (E-mail from F. Damerow } \\
\text { to R. A. Peterson, May 8, 2009, included in } \\
\text { Appendix A). }{ }^{\text {(a) }}\end{array}$ \\
\hline
\end{tabular}

\section{Test Exceptions}

The work reported herein is in direct response to Test Exception 24590-WTP-TEF-08-00012. This Test Exception outlines a matrix of experiments to be done to evaluate any impact of the presence of antifoaming agent on the oxidative leaching of a series of criticality-important elements as well as $\mathrm{Cr}$ itself from a simulant made through a specified preparation method. The matrix primarily examines the impact of temperature and AFA concentration on the oxidative leaching process. The Test Exception also outlines work to be done with two radioactive Hanford tank sludges and provides that the results of this Test Exception be presented in a stand-alone report. No AFA testing results will be reported for actual tank waste.

(a) Documented in Corrective Action Report CAR \#48697.1. 


\section{Exceptions to the Test Specifications}

This Test Plan followed the guidance provided by the Test Specification 24590-PTF-TSP-RT-06-002, Rev 0 and Test Exception 24590-WTP-TEF-RT-07-00016 with exceptions listed in Table S.2:

Table S.2. Exceptions to the Test Specifications and Their Justification

\begin{tabular}{||l|l||}
\hline Exception & \multicolumn{1}{|c|}{ Justification } \\
\hline $\begin{array}{l}\text { 1. Inhibited water }(0.01 \mathrm{M} \mathrm{NaOH}+0.01 \mathrm{M} \\
\mathrm{NaNO}_{2} \text { ) will be used instead of deionized (DI) } \\
\text { water to wash the slurry (see Steps 2.6 and 2.10). }\end{array}$ & $\begin{array}{l}\text { 1. Slightly basic water is preferred for sludge } \\
\text { washing to maintain solubility of aluminum } \\
\text { hydroxides. }\end{array}$ \\
\hline $\begin{array}{l}\text { 2. The Cs ion exchange testing will be conducted } \\
\text { using the alternative ion exchanger, spherical } \\
\text { resorcinol-formaldehyde (RF) resin instead of } \\
\text { SL-644. }\end{array}$ & 2. The RF resin is the new baseline resin. \\
\hline $\begin{array}{l}\text { 3. Parametric testing with the Cells Unit Filter } \\
\text { (CUF) was included in the Test Plan. }\end{array}$ & $\begin{array}{l}\text { 3. Additional testing is needed to provide useful } \\
\text { filtration data required in Test Specification } \\
\text { 24590-PTF-TSP-RT-06-003 Rev 0 for actual } \\
\text { waste testing to resolve Issue M12 } \\
\text { (24590-WTP-PL-ENG-06-0024). }\end{array}$ \\
\hline $\begin{array}{l}\text { 4. Additional analytical testing was included in } \\
\text { Task 5 and Task 6. }\end{array}$ & $\begin{array}{l}\text { 4. Additional testing was requested from } \\
\text { Engineering (BNI) to support process modeling } \\
\text { efforts. }\end{array}$ \\
\hline $\begin{array}{l}\text { 5. Caustic (19 M NaOH) will be added if needed to } \\
\text { increase the free hydroxide concentration to the } \\
\text { range of 0.1 to 0.25 M. }\end{array}$ & $\begin{array}{l}\text { 5. It is possible that the washing alone will be } \\
\text { sufficient to bring the free hydroxide to the } \\
\text { required range of 0.1 to 0.25 M. In this case, no } \\
\text { additional NaOH will be added. }\end{array}$ \\
\hline $\begin{array}{l}\text { 6. Results of the radioactive simulant tests were } \\
\text { not verified with actual waste tests with the } \\
\text { Group 6 S-Saltcake waste solids. }\end{array}$ & $\begin{array}{l}\text { 6. Since 1) addition of AFA did not affect the } \\
\text { extent of Pu dissolution from the simulant, and } \\
\text { 2) the Pu in the actual waste has generally been } \\
\text { less amenable to oxidation relative to the Pu in the } \\
\text { simulant, a decision was made by BNI not to test } \\
\text { with the actual waste. (E-mail from F. Damerow } \\
\text { to R. A. Peterson, May 8, 2009, included in } \\
\text { Appendix A). }\end{array}$ \\
\hline
\end{tabular}

(a) Documented in Corrective Action Report CAR \#48697.1. 


\section{Results and Performance Against Success Criteria}

Table S.3 describes the success criterion and explains how the criterion was met or not.

Table S.3. Success Criterion

\begin{tabular}{|c|c|}
\hline Success Criterion & Explain How the Tests Did or Did Not Meet the Success Criterion \\
\hline $\begin{array}{l}\text { Successful demonstration of the } \\
\text { oxidative leaching process using actual } \\
\text { waste under conditions that simulate } \\
\text { the anticipated plant flowsheet } \\
\text { conditions for the anticipated } \\
\text { pretreatment process systems: } \\
\text { crossflow ultrafiltration, caustic } \\
\text { leaching, water washing, oxidative } \\
\text { leaching, water washing, ion exchange, } \\
\text { and evaporation. This includes } \\
\text { demonstration of Cr removal from the } \\
\text { solids fraction, effective filtration } \\
\text { through the CUF, and no measurable } \\
\text { retention of Pu in the ion exchanger. }\end{array}$ & Provided in report WTP-RPT-171, Rev 0. \\
\hline $\begin{array}{l}\text { Determination of concentrations, } \\
\text { closure of mass balances, and } \\
\text { speciation of } \mathrm{Cr}, \mathrm{Pu} \text {, and } \mathrm{Mn} \text { in solution } \\
\text { as well as the fate of } \mathrm{B}, \mathrm{Cd}, \mathrm{Cr}, \mathrm{Pu}, \mathrm{Fe}, \\
\text { and Ni in solution for the anticipated } \\
\text { pretreatment process systems } \\
\text { (crossflow filtration, caustic leaching, } \\
\text { water washing, oxidative leaching, } \\
\text { water washing, ion exchange, and } \\
\text { evaporation). }\end{array}$ & Provided in report WTP-RPT-171, Rev 0. \\
\hline $\begin{array}{l}\text { Measurement of selected metal } \\
\text { concentrations of solids (that are } \\
\text { soluble in } 2 \mathrm{M} \text { nitric acid) associated } \\
\text { with the pretreatment-system } \\
\text { component surfaces, including Pu (for } \\
\text { potential enrichment). }\end{array}$ & Provided in report WTP-RPT-171, Rev 0. \\
\hline $\begin{array}{l}\text { Determination of selected metal analyte } \\
\text { composition, including Pu, of bulk } \\
\text { precipitated solids (if any) in the feed } \\
\text { evaporator process system (evaporator } \\
\text { bottoms and scale). }\end{array}$ & Provided in report WTP-RPT-171, Rev 0. \\
\hline $\begin{array}{l}\text { Determine the effect of AFA } \\
\text { concentration on oxidative leaching of } \\
\text { chromium. }\end{array}$ & This criterion was met and described in Chapter 3 of this report. \\
\hline $\begin{array}{l}\text { Provide a graphical correlation (plot) of } \\
\text { the effect of AFA on oxidative leaching } \\
\text { of chromium to Process } \\
\text { Engineering/Operations. }\end{array}$ & $\begin{array}{l}\text { Met success criterion. Figure } 3.4 \text { is a plot of } \mathrm{Cr} \text { removal from the solids } \\
\text { by oxidative leaching at either } 25^{\circ} \mathrm{C} \text { or } 45^{\circ} \mathrm{C} \text { as a function of AFA } \\
\text { concentration. }\end{array}$ \\
\hline
\end{tabular}


Table S.3. Success Criterion

\begin{tabular}{|c|c|}
\hline Success Criterion & Explain How the Tests Did or Did Not Meet the Success Criterion \\
\hline $\begin{array}{l}\text { Provide a graphical correlation (plot) of } \\
\text { the effect of AFA on oxidative leaching } \\
\text { of plutonium and the criticality related } \\
\text { elements to Process } \\
\text { Engineering/Operations. The criticality } \\
\text { related elements in the simulant include } \\
\text { Fe, Ni, and Mn. }\end{array}$ & $\begin{array}{l}\text { Met success criterion. Figures } 3.7 \text { through } 3.27 \text { plot results as a function } \\
\text { of AFA concentration for iron, nickel, manganese and plutonium. Note } \\
\text { that this criterion can only refer to the radioactive simulant tests given in } \\
\text { the presence of Pu and U as part of the safety critical elements to be } \\
\text { evaluated. The specific elements designated as safety critical are } \\
\text { provided in Test Specification } 24590-P T F-T S P-R T-06-002 \text {, Rev } 0 \text {, } \\
\text { "Process Development for Design of Oxidative Leaching of Hanford } \\
\text { Wastes."(a) }\end{array}$ \\
\hline $\begin{array}{l}\text { Verification of the results from the } \\
\text { radioactive simulant tests at a minimum } \\
\text { of two test conditions using the waste } \\
\text { solids from Group } 6 \mathrm{~S}-\text { Saltcake waste. } \\
\text { Verification results will be plotted } \\
\text { against Success Criteria } 1 \text { and } 2 \text { above. }\end{array}$ & Direction was given by BNI to not test with actual waste. ${ }^{(b)}$ \\
\hline
\end{tabular}

\section{Quality Requirements}

The PNNL Quality Assurance Program is based upon the requirements as defined in the U.S. Department of Energy (DOE) Order 414.1C, Quality Assurance and 10 CFR 830, Energy/Nuclear Safety Management, Subpart A-Quality Assurance Requirements (a.k.a. the Quality Rule). PNNL has chosen to implement the following consensus standards in a graded approach:

- ASME NQA-1-2000, Quality Assurance Requirements for Nuclear Facility Applications, Part 1, Requirements for Quality Assurance Programs for Nuclear Facilities

- ASME NQA-1-2000, Part II, Subpart 2.7, Quality Assurance Requirements for Computer Software for Nuclear Facility Applications

- ASME NQA-1-2000, Part IV, Subpart 4.2, Graded Approach Application of Quality Assurance Requirements for Research and Development.

The procedures necessary to implement the requirements are documented in PNNL's "How do I...?" (HDI). ${ }^{(\mathrm{c})}$

PNNL implemented the RPP-WTP quality requirements by performing work in accordance with the River Protection Project-Hanford Tank Waste Treatment and Immobilization Plant Support Program (RPP-WTP) Quality Assurance Plan (RPP-WTP-QA-001, QAP). Work was performed to the quality requirements of NQA-1-1989 Part I, Basic and Supplementary Requirements, NQA-2a-1990, Part 2.7, and DOE/RW-0333P, Rev 13, Quality Assurance Requirements and Descriptions (QARD). These quality requirements were implemented through the River Protection Project-Waste Treatment Plant Support Program (RPP-WTP) Quality Assurance Manual (RPP-WTP-QA-003, QAM). The analytical

(a) PS Sundar. 2006. Process Development for Design of Oxidative Leaching of Hanford Wastes. 24590-PTF-TSP-RT-06-002, Rev. 0, Bechtel National, Incorporated, Richland, Washington.

(b) An e-mail note from F Damerow (BNI) to RA Peterson (PNNL) on May 08, 2009, communicated this decision. Email included in Appendix A.

(c) PNNL's system for managing the delivery of laboratory-level policies, requirements, and procedures. 
requirements are implemented through RPP-WTP's Statement of Work (WTPSP-SOW-005 and RPP-WTP-QA-005, respectively) with the Radiochemical Processing Laboratory (RPL) Analytical Support Operations (ASO). The requirements of DOE/RW-0333P, Rev 13, Quality Assurance Requirements and Descriptions (QARD) were not required for this work.

PNNL addressed internal verification and validation activities by conducting an Independent Technical Review of the final data report in accordance with PNNL's procedure QA-RPP-WTP-604. This review verifies that the reported results were traceable, inferences and conclusions were soundly based, and the reported work satisfied the Test Plan objectives. This review procedure is part of PNNL's RPP-WTP Quality Assurance Manual.

\section{R\&T Test Conditions}

Table S.4 lists the research and technology test conditions and whether they were followed.

Table S.4. List of R\&T Test Conditions and Whether They Were Followed

\begin{tabular}{|c|c|}
\hline List R\&T Test Conditions & Were Test Conditions Followed? \\
\hline \multicolumn{2}{|l|}{ Actual Waste Selection and Compositing } \\
\hline $\begin{array}{l}4 \text { to } 5 \mathrm{~L} \text { of actual tank waste will be obtained with } \\
\text { sludge, saltcake, and supernatant components. Saltcake } \\
\text { will be dissolved in water before being added to sludge. }\end{array}$ & Provided in report WTP-RPT-171, Rev 0. \\
\hline $\begin{array}{l}\text { The tank waste components will be composited in a } \\
\text { stainless steel vessel. Mixing will be effected using an } \\
\text { overhead stirrer equipped with a suitable stir blade. } \\
\text { Homogenization will be evaluated from three } \\
\text { subsamples collected from the vessel at three different } \\
\text { levels (one sample per level) and will be based on equal } \\
( \pm 1.5 \%) \text { slurry densities. }\end{array}$ & Provided in report WTP-RPT-171, Rev 0. \\
\hline \multicolumn{2}{|l|}{ Oxidant Dosage Testing } \\
\hline $\begin{array}{l}\text { Nonradioactive simulant was tested with } \mathrm{Cr}_{2} \mathrm{O}_{3} \text { and } \\
\mathrm{Cr}(\mathrm{O})(\mathrm{OH})-\mathrm{H}_{2} \mathrm{O} \text { to determine the effect of mixing } \\
\text { conditions, hydroxide concentration, temperature, and } \\
\text { initial }\left[\mathrm{MnO}_{4}\right] /[\mathrm{Cr}] \text { ratio on the effectiveness of } \\
\text { oxidative leaching. The initial }\left[\mathrm{MnO}_{4}\right] /[\mathrm{Cr}] \text { ratio was } \\
\text { varied from } 0.75 \text { to } 1.25 \text { at } 25^{\circ} \mathrm{C} \text { and } 45^{\circ} \mathrm{C} \text { in caustic } \\
\text { solutions that ranged from } 0.25 \text { to } 3 \mathrm{M} \mathrm{NaOH} \text {. }\end{array}$ & Provided in report WTP-RPT-171, Rev 0. \\
\hline \multicolumn{2}{|l|}{ Demonstration Test } \\
\hline $\begin{array}{l}\text { Nonradioactive simulant was tested with } \mathrm{Cr}_{2} \mathrm{O}_{3} \text { and } \\
\mathrm{Cr}(\mathrm{O})(\mathrm{OH})-\mathrm{H}_{2} \mathrm{O} \text { to determine the effect of mixing } \\
\text { conditions, hydroxide concentration, temperature, and } \\
\text { initial }\left[\mathrm{MnO} \mathrm{O}_{4}\right] /[\mathrm{Cr}] \text { ratio on the effectiveness of } \\
\text { oxidative leaching. The initial }\left[\mathrm{MnO}_{4}\right] /[\mathrm{Cr}] \text { ratio was } \\
\text { varied from } 0.75 \text { to } 1.25 \text { at } 25^{\circ} \mathrm{C} \text { and } 45^{\circ} \mathrm{C} \text { in caustic } \\
\text { solutions that ranged from } 0.25 \text { to } 3 \mathrm{M} \mathrm{NaOH} \text {. }\end{array}$ & Provided in report WTP-RPT-171, Rev 0. \\
\hline
\end{tabular}




\section{Simulant Use}

A simulant previously developed for monitoring the impact of changing permanganate dosage on chromium(III) conversion to soluble chromate in alkaline solutions was used in these tests. The simulant was designed to evaluate $\mathrm{Cr}$ removal as a function of AFA concentration and changing leaching conditions. Chromium(III) oxyhydroxide hydrate was used for the leaching tests. The other components in the simulant were generally based on observed phases present in Hanford tank sludge solids, but their presence, with the exception of $\mathrm{Cr}$, was based primarily on their importance to criticality safety, and concentrations were motivated primarily for detection convenience.

Plutonium nitrate, containing americium-241 in-grown from plutonium-241 decay, was mixed with ferric nitrate in a nitric acid solution. The iron and plutonium plus americium were coprecipitated by neutralizing the nitric acid with sodium hydroxide. A mixture of U(IV) and U(VI) oxides was mixed with the oxide/hydroxides of chromium, nickel, and zinc to form the simulant slurry used in testing. No manganese was added to the initial simulant preparation. During simulant characterization, some aliquots indicated the presence of traces of Mn that may have been present as impurities or were an analytical artifact of the complex sample matrix. The antifoam agent was added to individual aliquots of the slurry and allowed to equilibrate for at least 24 hours before leach testing.

\section{Discrepancies and Follow-On Tests}

The Test Exception and Test Plan specified stirring during the caustic leaching sufficient to maintain suspended solids. Due to experimental difficulties, the caustic leaching system was agitated by rotary shaking at $200 \mathrm{rpm}$. It is not believed that this change impacted the conclusions in this report. All tests were conducted using the same method for mixing, so the relative effects are consistent. In addition, the conclusions are based solely on the radioactive simulant and were not verified with actual waste testing. Confirmation of the simulant conclusions with actual waste would be useful.

The four tests with an $\mathrm{Mn} / \mathrm{Cr}$ ratio of 1.25 were inadvertently carried out at a ratio of 1.0. The result of this action is that all tests were conducted with the $\mathrm{Mn} / \mathrm{Cr}$ ratio of 1.0, i.e., no excess permanganate.

Due to interference from the analytical preparation method for solids dissolution, nickel was not measured in the solids and all conclusions were based on the result that nickel was not observed in the leachate solutions. Additional testing would be required to confirm these conclusions based on analysis of solids.

The Test Exception requested confirmatory tests with actual waste samples. However, based on the limited impact observed from the simulant studies, a decision was made by WTP to not carry out the actual waste tests. This was documented in an e-mail message from Fred Damerow on May 08, 2009. 



\section{Acknowledgements}

The authors would like to thank Pacific Northwest National Laboratory staff members Wayne Cosby for his editorial support and Bruce McNamara for obtaining the uranium compounds used in this report. The authors also would like to thank Parameshwaran Sundar of Bechtel National Inc. for his technical insights and much helpful discussion and support. 



\subsection{Introduction}

Oxidative leaching of simulant tank waste using permanganate as the oxidant in $0.25 \mathrm{M} \mathrm{NaOH}$ solutions reduces the chromium content of the sludge. An antifoam agent (AFA) is added to the waste treatment process to reduce foaming. The AFA, Dow Corning Q2-3183A, is a surface-active polymer that consists of polypropylene glycol, polydimethylsiloxane, octylphenoxy polyethoxy ethanol, treated silica, and polyether polyol. Some of the Hanford Tank Waste Treatment and Immobilization Plant (WTP) waste slurries contain high concentrations of undissolved solids that would exhibit undesirable behavior without AFA addition.

These tests were conducted to determine the effect of the AFA on oxidative leaching of $\mathrm{Cr}$ (III) in waste by permanganate. Previous studies have demonstrated that the $\mathrm{Cr}$ (III) oxidation can be used to produce soluble chromium $(\mathrm{Cr}(\mathrm{VI}))$ according to the reaction:

$$
\mathrm{Cr}(\mathrm{OH})_{3}+\mathrm{MnO}_{4}^{-}+\mathrm{OH}^{-} \rightleftharpoons \mathrm{CrO}_{4}{ }^{2-}+\mathrm{MnO}_{2}+2 \mathrm{H}_{2} \mathrm{O}
$$

It has not previously been determined what effect AFA has on the permanganate reaction. This study was conducted to determine the effect AFA has on the oxidation of the chromium, plus plutonium and other criticality-related elements, specifically Fe, Ni, and Mn. During the oxidative leaching process, $\mathrm{Mn}$ is added as liquid permanganate solution and is converted to an insoluble solid that precipitates as $\mathrm{MnO}_{2}$ and becomes part of the solid waste. Caustic leaching was performed followed by an oxidative leach at either $25^{\circ} \mathrm{C}$ or $45^{\circ} \mathrm{C}$. The test conditions for these tests are shown in Table 1.1.

Table 1.1. Test Conditions for Radioactive Simulant Testing

\begin{tabular}{cccc}
\hline Test Number & Temperature, ${ }^{\circ} \mathrm{C}$ & AFA Level, $\mathrm{mg} / \mathrm{L}^{(\mathrm{a})}$ & $\mathrm{Mn}: \mathrm{Cr}$ \\
\hline 1 & 25 & 175 & 1.0 \\
2 & 25 & 350 & 1.0 \\
3 & 25 & 350 & 1.0 \\
$4^{(\mathrm{b})}$ & 25 & 700 & 1.0 \\
5 & 45 & 350 & $1.0^{(\mathrm{c})}$ \\
6 & 45 & 700 & $1.0^{(\mathrm{c})}$ \\
7 & 45 & 350 & $1.0^{(\mathrm{c})}$ \\
$8^{(\mathrm{b})}$ & 25 & 0 & 1.0 \\
9 & 45 & 700 & 1.0 \\
10 & 25 & 700 & $1.0^{(\mathrm{c})}$ \\
\hline
\end{tabular}

(a) AFA concentration in the feed simulant before caustic leaching step.

(b) Test carried out in triplicate to assess experimental variance.

(c) Test Exception called for 1.25 ratio.

Details of the testing are presented in the Experimental Section of this report. An overview is presented here. The simulant was prepared using a previously developed recipe and was aliquoted into individual test items. Water and sodium hydroxide were added to each test item to give a leachate volume equal to three times the simulant sludge volume with a caustic concentration of $3 \mathrm{M} \mathrm{NaOH}$. AFA was mixed with a small quantity of $\mathrm{NaOH}$ solution and was added to the items as specified in Table 1.1.. The simulant and supernate/leachate were mixed for 24 hours at room temperature to equilibrate with the 
$3 \mathrm{M} \mathrm{NaOH}$, after which the solids and liquids were sampled to determine the starting concentrations of elements of interest. These steps are shown in Figure 1.1.

Adjust $\mathrm{NaOH}$ to $3 \mathrm{M}$ Volume $3 \times$ Simulant and Add

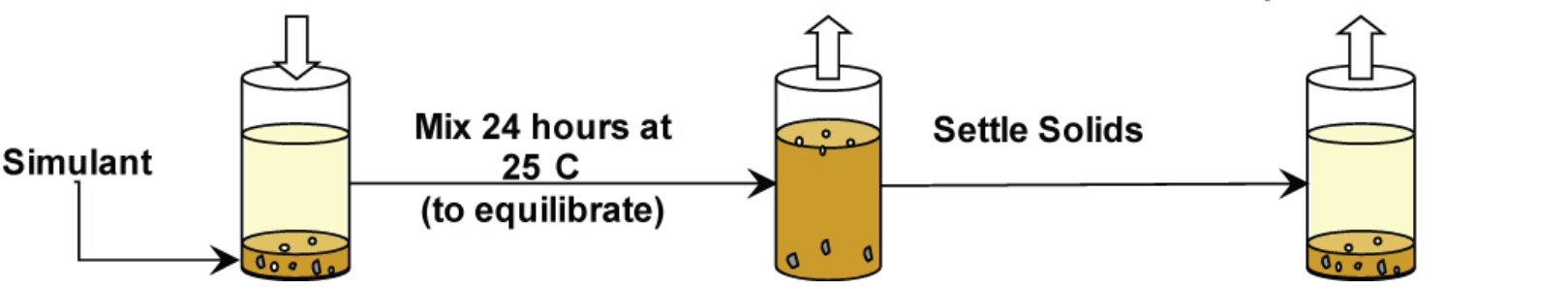

Figure 1.1. Initial Equilibration of Simulant Sludge with $3 \mathrm{M} \mathrm{NaOH}$

Each test item was subjected to a caustic leach process by heating and mixing the items at $85 \pm 5^{\circ} \mathrm{C}$ for 8 hours. The caustic was $3 \mathrm{M} \mathrm{NaOH}$. After 8 hours at $85 \pm 5^{\circ} \mathrm{C}$, the test items were cooled overnight to room temperature, and any lost water was replenished. The amount of water lost was less than $1 \mathrm{~mL}$ in all cases, so the caustic concentration increased by no more than $0.8 \%$ due to water loss. The samples were mixed, the solids were sampled and the supernatant leachate was separated from the solids. The solids were washed twice with $0.01 \mathrm{M} \mathrm{NaOH}$ and the wash solutions were added to the supernate. Previous testing for oxidative leaching used three washes and it was observed that the highly-colored chromate was mostly removed after two washes. Reducing the number of washes to two, reduced the combined volume of washes and supernate. The reduced volume inproved detectability of analytes present at very low concentrations. After thorough mixing, the supernate/wash solution was sampled. These steps are depicted in Figure 1.2. 


\section{Equilibrated}

Simulant and

$3 \mathrm{M} \mathrm{NaOH}$

Sample Slurry for
Solids - CL-S

$$
\text { Solids - CL-S }
$$

Decant Caustic Leach

Supernate - CL-Su
Wash with $0.01 \mathrm{M} \mathrm{NaOH}$

3X Simulant Volume

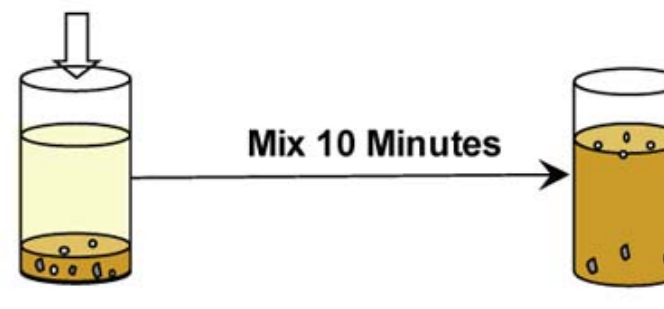

Wash with $0.01 \mathrm{M} \mathrm{NaOH}$

3X Simulant Volume

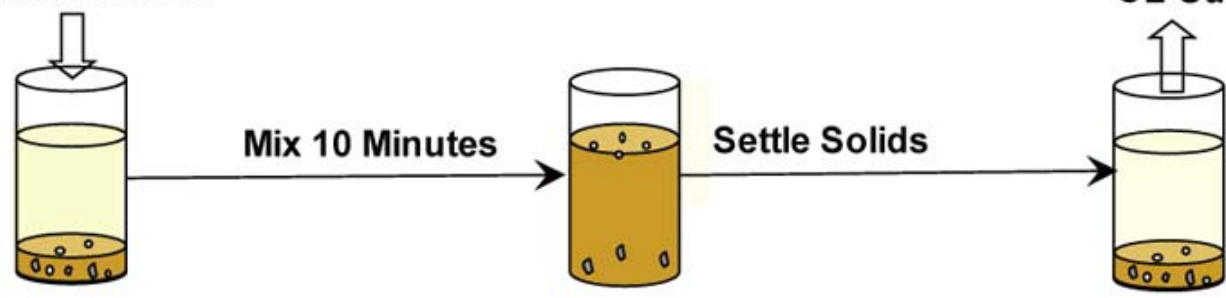

Decant Wash and Add to Caustic Leach Supernate CL-Su

Figure 1.2. Caustic-Leach and Wash of Simulant Sludge

The caustic leached and washed solids were combined with water, $\mathrm{NaOH}$, and $\mathrm{NaMnO}_{4}$ to produce an oxidative-leach solution that contained $0.25 \mathrm{M} \mathrm{NaOH}$ and permanganate at a concentration to produce a 1:1 chromium to permanganate ratio. The test item was heated to the temperature specified in Table 1.1. for six hours with mixing. At the end of this time, the solids were settled and the supernate/leachate was decanted, the solids were washed twice with $0.01 \mathrm{M} \mathrm{NaOH}$, and the wash solutions were combined with the oxidative-leach supernate. After mixing well, the leachate/wash solution was sampled. The solids were dried and submitted for analysis. The oxidative-leach steps are shown in Figure 1.3. 
Add $0.25 \mathrm{M} \mathrm{NaOH}$

Add $\mathrm{NaMnO}_{4}$
Decant Oxidative Leach

Supernate - OL-Su

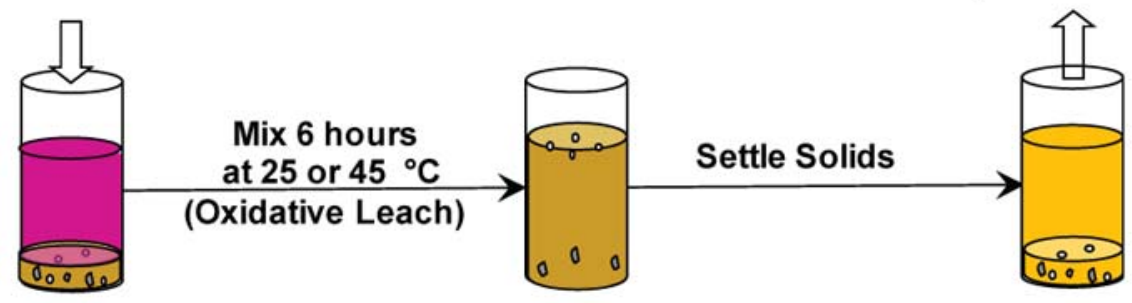

Wash with $0.01 \mathrm{M} \mathrm{NaOH}$

Decant Wash and Add to 3X Simulant Volume Oxidative Leach Supernate

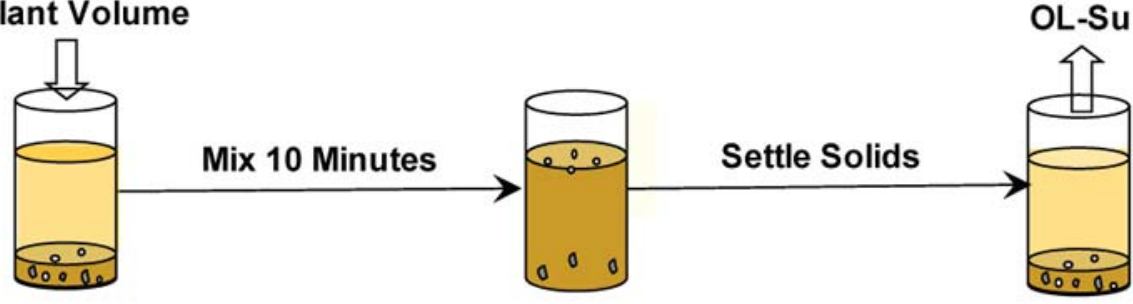

Wash with $0.01 \mathrm{M} \mathrm{NaOH}$ 3X Simulant Volume

Decant Wash and Add to Oxidative Leach Supernate

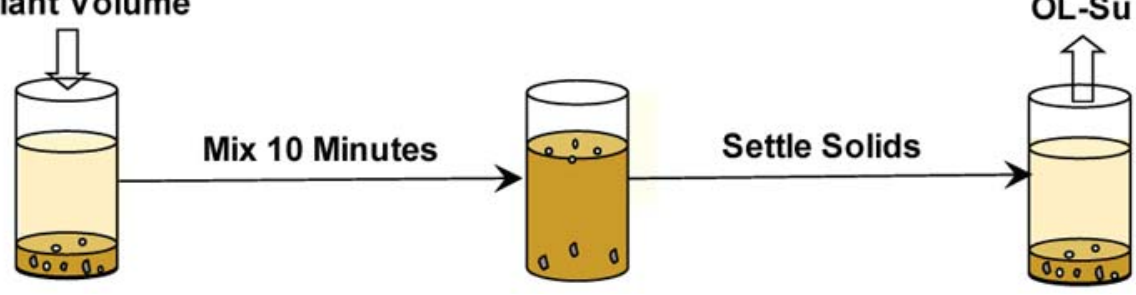

Figure 1.3. Oxidative-Leach Steps

In this document, the test item is a radioactive simulant solid material in liquid. The solid may be suspended into a slurry or settled into compacted solids. The settling may be accomplished by gravity or induced by centrifugation. When the maximum amount of settling has resulted in the minimum volume of solids, the solids are considered settled solids or compacted solids. Liquid is added to the solids for the purpose of either leaching material out with a leachate or washing the solids to remove interstitial leachate. When the solids are settled, the liquid may be referred to as either leachate or supernate interchangeably. Mixing settled solids and leachate or wash solution by agitation results in a slurry. When all of the liquid is removed, the residue is dried solids.

In summary, this report describes work focused on determining the effect of AFA on chromium oxidation by permanganate with Hanford sludge simulant. 


\subsection{Experimental Section}

The experimental details relevant to the work described in this report are provided in this section, which begins with general equipment and analytical information. It then proceeds to the details of producing and characterizing the $\mathrm{Cr}(\mathrm{III})$-containing solids to be used in this work.

\subsection{General Experimental Information}

All commercially-supplied chemicals were of reagent grade unless otherwise specified. The uranium and plutonium were obtained from in-house stores. The hydroxide concentrations in the stock sodium hydroxide solutions were verified by titration with primary standard acid solutions and were performed by the Radiochemical Processing Laboratory's (RPL's) Analytical Support Operations (ASO) using standard procedures. The permanganate concentrations in stock sodium permanganate solutions were verified by titration against standards-grade sodium oxalate according to a literature procedure (Jeffery et al. 1989).

The ASO at PNNL performed all sample analyses, hydroxide concentration determination by titration, uranium concentrations by inductively coupled plasma-optical emission spectroscopy (ICP-OES), plutonium and americium by alpha energy analysis (AEA), total metals by ICP-OES, anions by ion chromatography (IC), total inorganic carbon (TIC), and total organic carbon (TIC) by the hot persulfate method. The measurements using standard procedures were performed under statement of work SOW-RPP-WTP-QA-005.

\subsection{Preparation of Radioactive Simulant}

The composition of the solids constituents for preparing the radioactive simulant was in accordance with those described in a prior publication (Rapko et al. 2007). However, adding $\mathrm{Fe}(\mathrm{OH})_{3}$ and $\mathrm{Pu}(\mathrm{IV})$ to the simulant sludge was accomplished differently than before, specifically by neutralizing a solution containing both $\mathrm{Fe}\left(\mathrm{NO}_{3}\right)_{3}$ and $\mathrm{Pu}\left(\mathrm{NO}_{3}\right)_{4}$ from an acidic medium with $\mathrm{NaOH}$. Furthermore, it was not recommended that this coprecipitated $\mathrm{Fe}(\mathrm{OH})_{3}+\mathrm{Pu}(\mathrm{OH})_{4}$ be washed to separate the nitrate anion. Instead, BNI accepted the small amount of this nitrate anion in the simulant supernate composition. At this point, the simulant supernate should consist only of hydroxide anion and a residual concentration of nitrate anion from $\mathrm{Fe}$ and $\mathrm{Pu}(\mathrm{IV})$ coprecipitation. This procedure for adding $\mathrm{Pu}(\mathrm{IV})$ deviated from the addition of $\mathrm{Pu}\left(\mathrm{NO}_{3}\right)_{4}$ solution into a heterogeneous mixture of $\mathrm{Fe}(\mathrm{OH})_{3}, \mathrm{CrO}(\mathrm{OH})$, and other constituents in an alkaline medium. In this regard, the procedure for adding $\mathrm{Pu}(\mathrm{IV})$ follows that described in a prior WTP publication (Sinkov 2007). The chromium component added to prepare the simulant consisted of chromium oxyhydroxide $\mathrm{CrOOH}-\mathrm{nH}_{2} \mathrm{O}$ only. The $\mathrm{CrOOH}$ was added as a slurry without the drying and milling steps in its preparation described in the publication cited above (Rapko et al. 2007).

Table 2.1 provides information regarding the commercially procured chemicals used in preparing radioactive chromium leaching simulant. 
Table 2.1. Commercially-Procured Phases Used in the Simulant

\begin{tabular}{llll}
\hline Chemical Phase & Chemical Formula & Manufacturer & Lot. No. \\
\hline Ferric Nitrate & $\mathrm{Fe}\left(\mathrm{NO}_{3}\right) \cdot 9 \mathrm{H}_{2} \mathrm{O}$ & JT Baker & 34460 \\
Zinc Hydroxide & $\mathrm{Zn}(\mathrm{OH})_{2}$ & Wintersun Chemical & 051201 \\
Nickel Hydroxide & $\mathrm{Ni}(\mathrm{OH})_{2}$ & Alfa Aesar ${ }^{\circledR}$ & C24R009 \\
\hline
\end{tabular}

\subsubsection{Preparation of the Radioactive Chromium Leaching Simulant}

The initial components of the simulant were combined in the amounts listed in Table 2.2. Plutonium nitrate, containing americium-241 in-grown from plutonium-241 decay, was mixed with ferric nitrate in a nitric acid solution. The iron and plutonium plus americium were coprecipitated by neutralizing the nitric acid with sodium hydroxide. The precipitated iron, plutonium and americium were combined with a mixture of U(IV) and U(VI) oxides that were mixed with the oxide/hydroxides of chromium, nickel, and zinc to form the simulant slurry used in testing. No manganese was added to the initial simulant preparation. During simulant characterization, some aliquots indicated the presence of traces of Mn that may have been present as impurities or were an analytical artifact of the complex sample matrix.

Table 2.2. Initial Components Combined for the Radioactive Simulant

\begin{tabular}{|c|c|c|c|}
\hline & Component & Amount Added, g & Amount As Oxide, $g$ \\
\hline & $\mathrm{CrO}(\mathrm{OH})$ & $14.917^{\text {(a) }}$ & 13.336 \\
\hline & $\mathrm{Fe}(\mathrm{OH})_{3}$ & $25.007^{(b)}$ & 19.046 \\
\hline & $\mathrm{Ni}(\mathrm{OH})_{2}$ & 0.7014 & 0.565 \\
\hline & $\mathrm{UO}_{2}$ & 0.563 & 0.563 \\
\hline & $\beta-\mathrm{U}_{3} \mathrm{O}_{8}$ & 1.047 & 1.047 \\
\hline & $\mathrm{Zn}(\mathrm{OH})_{2}$ & 0.2241 & 0.219 \\
\hline & $\mathrm{Pu}(\mathrm{OH})_{4}$ & $0.022^{(\mathrm{c})}$ & 0.019 \\
\hline & Total Mass: & 42.4815 & 34.795 \\
\hline $\begin{array}{l}\text { (a) } \\
\text { (b) }\end{array}$ & \multirow{2}{*}{\multicolumn{3}{|c|}{$\begin{array}{l}\text { The } \mathrm{CrO}(\mathrm{OH}) \text { was obtained as a slurry and the mass was calculated from characterization data. } \\
\text { Iron was prepared as } 131.25 \mathrm{~g} \text { of } \mathrm{Fe}\left(\mathrm{NO}_{3}\right)_{3} \cdot 9 \mathrm{H}_{2} \mathrm{O} \text { in } 250 \mathrm{~mL} \text {. Only } 180 \mathrm{~mL} \text { was used and it was } \\
\text { neutralized by dropwise addition of } \mathrm{NaOH} \text {. } \\
\text { A solution containing } 17 \mathrm{mg} \mathrm{Pu}(\mathrm{IV}) \text { in nitric acid was neutralized with } \mathrm{NaOH} \text { and coprecipitated }\end{array}$}} \\
\hline (c) & & & \\
\hline
\end{tabular}

The plutonium added to the test samples was weapons-grade material with the isotopic distribution shown in Table 2.3. The americium concentration was calculated based on the known plutonium isotopic distribution and observed ratio of the alpha activity of $\left({ }^{238} \mathrm{Pu}+{ }^{241} \mathrm{Am}\right)$ relative to $\left({ }^{239} \mathrm{Pu}+{ }^{240} \mathrm{Pu}\right)$. The alpha energy analysis (AEA) used to measure plutonium in the samples detects a single energy peak for $\left({ }^{239} \mathrm{Pu}+{ }^{240} \mathrm{Pu}\right)$ and another peak for $\left({ }^{238} \mathrm{Pu}+{ }^{241} \mathrm{Am}\right)$. The quantities of the individual isotopes cannot be directly determined by this technique. Data for both $\left({ }^{239} \mathrm{Pu}+{ }^{240} \mathrm{Pu}\right)$ and $\left({ }^{238} \mathrm{Pu}+{ }^{241} \mathrm{Am}\right)$ is presented in this report. Any systematic differences between the results for these can be attributed to different behavior by plutonium compared to americium. 
Table 2.3. Isotopic Distribution for Plutonium Used in Simulant

\begin{tabular}{cccc}
\hline Isotope & $\begin{array}{c}\text { Isotopic Abundance } \\
(\mathrm{wt} \%)\end{array}$ & $\begin{array}{c}\text { Specific Alpha Activity } \\
(\mathrm{Ci} / \mathrm{g})\end{array}$ & $\begin{array}{c}\text { Alpha Activity } \\
(\mathrm{Ci} / \mathrm{g} \mathrm{Pu})\end{array}$ \\
\hline${ }^{238} \mathrm{Pu}$ & 0.0068 & $1.70 \mathrm{E}+01$ & $1.16 \mathrm{E}-03$ \\
${ }^{239} \mathrm{Pu}$ & 93.8957 & $6.20 \mathrm{E}-02$ & $5.82 \mathrm{E}-02$ \\
${ }^{240} \mathrm{Pu}$ & 6.0034 & $2.30 \mathrm{E}-01$ & $1.38 \mathrm{E}-02$ \\
${ }^{241} \mathrm{Pu}$ & 0.06924 & $1.00 \mathrm{E}+02$ & \\
${ }^{242} \mathrm{Pu}$ & 0.0247 & $3.90 \mathrm{E}-03$ & $9.63 \mathrm{E}-07$ \\
${ }^{241} \mathrm{Am}$ & 0.0057 & 3.4 & $1.93 \mathrm{E}-04$ \\
${ }^{238} \mathrm{Pu}+{ }^{241} \mathrm{Am}$ & 0.0124 & -- & $1.35 \mathrm{E}-05$ \\
${ }^{239} \mathrm{Pu}+{ }^{240} \mathrm{Pu}$ & 99.9 & -- & $7.20 \mathrm{E}-04$ \\
\hline
\end{tabular}

\subsubsection{Division of the Radioactive Simulant for Oxidative Leaching Experiments}

The following steps were taken to aliquot test samples containing nearly equal amounts of waste simulant. The simulant slurry was mixed with an overhead mechanical mixer. Using a pipetter equipped with a tip that had been trimmed at the end to prevent plugging, $31 \mathrm{~mL}$ of the mixed slurry was transferred to each of fourteen $250-\mathrm{mL}$ plastic bottles plus an extra bottle that contained approximately $27 \mathrm{~mL}$ of the mixed slurry. This amount of slurry was calculated to give $3.2 \mathrm{~g}$ of simulant solids in each bottle.

\subsection{Caustic-Leach Preparation}

The amount of reagents needed was calculated based on a 3:1 ratio of volume leachate to volume compacted solids. The radioactive simulant had an initial caustic concentration of $1.86 \mathrm{M}$. To attain the 3:1 leachate volume at a concentration of $3 \mathrm{M} \mathrm{NaOH}$, deionized (DI) water was first added and followed by $10 \mathrm{M} \mathrm{NaOH}$ stock solution. To mix the leachate with the sludge simulant, the slurries with added leachate were mixed for at least 10 minutes on a shaker table at $200 \mathrm{rpm}$ and room temperature. The volumes of compacted solids slurry and added leach solution are shown in Table 2.4. 
Table 2.4. Caustic-Leach Volumes Used with Radioactive Simulant Testing

\begin{tabular}{ccc}
\hline Test & $\begin{array}{c}\text { Total Initial Slurry } \\
\text { Volume }(\mathrm{mL})\end{array}$ & $\begin{array}{c}\text { Total Volume Leach } \\
\text { Solution }(\mathrm{mL})\end{array}$ \\
\hline 1 & 31.58 & 126 \\
2 & 30.79 & 123 \\
3 & 31.20 & 125 \\
$4 \mathrm{a}$ & 31.03 & 124 \\
$4 \mathrm{~b}$ & 31.09 & 124 \\
$4 \mathrm{c}$ & 31.19 & 125 \\
5 & 30.68 & 123 \\
6 & 31.02 & 124 \\
7 & 30.72 & 123 \\
$8 \mathrm{a}$ & 30.91 & 124 \\
$8 \mathrm{~b}$ & 31.07 & 124 \\
$8 \mathrm{c}$ & 30.71 & 123 \\
9 & 31.09 & 124 \\
10 & 30.71 & 123 \\
\hline
\end{tabular}

\subsection{Test Sample Preparation and Characterization}

The AFA testing used Dow Corning® Q2-3183A AFA at levels of 0 to $700 \mathrm{ppm}(0$ to $700 \mathrm{mg} / \mathrm{L})$. This AFA consists of polypropylene glycol, polydimethylsiloxane, octylphenoxy polyethoxy ethanol, treated silica, and polyether polyol. The designated amount of AFA was added to each test slurry as indicated in Table 2.5. The target was based on a multiplier to produce a final concentration of AFA in $\mathrm{mg} / \mathrm{L}$ of slurry. The WTP process uses a nominal $350 \mathrm{ppm}$ AFA concentration. The selected test concentrations are equal to $0,0.5,1$, and 2 times the plant concentration. Table 2.5 contains the specific amounts of AFA added to each test item. 
Table 2.5. AFA Concentrations in Radioactive Simulant

\begin{tabular}{cccc}
\hline Test & $\begin{array}{c}\text { Total Slurry } \\
\text { Volume }(\mathrm{mL})\end{array}$ & $\begin{array}{c}\text { AFA target } \\
(\mathrm{mg} / \mathrm{L})\end{array}$ & $\begin{array}{c}\text { AFA added } \\
(\mathrm{mg})\end{array}$ \\
\hline 1 & 31.58 & 175 & 5.5 \\
2 & 30.79 & 350 & 10.8 \\
\hline 3 & 31.20 & 350 & 10.9 \\
$4 \mathrm{a}$ & 31.03 & 700 & 21.7 \\
$4 \mathrm{~b}$ & 31.09 & 700 & 21.8 \\
$4 \mathrm{c}$ & 31.19 & 700 & 21.8 \\
\hline 5 & 30.68 & 350 & 10.7 \\
\hline 6 & 31.02 & 700 & 21.7 \\
\hline 7 & 30.72 & 350 & 10.8 \\
$8 \mathrm{a}$ & 30.91 & 0 & 0.0 \\
\hline $8 \mathrm{~b}$ & 31.07 & 0 & 0.0 \\
$8 \mathrm{c}$ & 30.71 & 0 & 0.0 \\
\hline 9 & 31.09 & 700 & 21.8 \\
\hline 10 & 30.71 & 700 & 21.5 \\
\hline
\end{tabular}

The test mixtures containing sludge simulant, $3 \mathrm{M} \mathrm{NaOH}$ leachate, and AFA at the targeted level were placed on an orbital shaker table at room temperature, and the slurries were agitated at $200 \mathrm{rpm}$ for 24 hours. Solids were allowed to settle until a clear supernate was observed. Samples of the supernate were collected and filtered. From each test item, one sample was submitted for free hydroxide, anions by IC, TIC, and TOC analyses. A second sample of the supernate was submitted for metals analysis by ICP-OES and plutonium $(\mathrm{Pu})$ by AEA. The slurries were mixed vigorously, and a third sample of the solids was collected as a slurry. The solids were washed with $0.01 \mathrm{M} \mathrm{NaOH}$, dried, and analyzed for metals and $\mathrm{Pu}$. The washing of these solids was incomplete because of the small sample size and the solids that settled poorly.

The test containers were loosely capped and placed in the heated shaker table. Slurries were agitated by rotary shaking at $200 \mathrm{rpm}$ and heated at $85^{\circ} \mathrm{C} \pm 5^{\circ} \mathrm{C}$ for 8 hours. After 8 hours at $85 \pm 5^{\circ} \mathrm{C}$, the test items were cooled overnight to room temperature, and any lost water was replenished. The amount of water lost was less than $1 \mathrm{~mL}$ in all cases, so the caustic concentration increased by no more than $0.8 \%$ due to water loss. The samples were mixed, evaporated liquid was replenished with DI water, stirring was stopped, and the sample was allowed to settle. Supernate was decanted into tared plastic bottles and weighed. The leached solids remaining in each caustic leachate bottle were washed by adding $0.01 \mathrm{M} \mathrm{NaOH}$ (in an equivalent amount to the leach solution) into each test container and agitated for at least 10 minutes, and again the solids were allowed to settle. The wash solution was decanted into the appropriate tared plastic bottle containing the previous supernate. The wash with $0.01 \mathrm{M} \mathrm{NaOH}$ was repeated for a second wash.

After agitating each supernate- and washes-containing bottle for at least 5 minutes at $200 \mathrm{rpm}$ on the shaker table to confirm that the contents were well mixed, an aliquot of sample from each bottle was removed and filtered through a $0.2-\mu \mathrm{m}$ syringe filter into a vial. From each test caustic-leach item, one sample was submitted for free hydroxide, TIC, and TOC analyses. A second sample of the supernate was submitted for metals analysis by ICP-OES and Pu by AEA. The slurries were mixed vigorously, and a 
third sample of the solids was collected as a slurry. The solids were washed with $0.01 \mathrm{M} \mathrm{NaOH}$, dried, and analyzed for metals and $\mathrm{Pu}$. Concentrations of key components in the radioactive simulant are shown in the Results section. All of the ICP results for the initial sample characterization are reported in Appendix B.

\subsection{Oxidative-Leach Procedure}

The amount of reagents needed was calculated based on a 3:1 volume leachate to volume compacted solids for each oxidative-leach test. The amount of $\mathrm{NaOH}$ needed to achieve the desired $0.25 \mathrm{M} \mathrm{NaOH}$ concentration was calculated based on the amounts of residual $3 \mathrm{M} \mathrm{NaOH}$ and volumes of $0.01 \mathrm{M} \mathrm{NaOH}$ wash solution used in the caustic-leach and wash steps. Water was added first, then the $10 \mathrm{M} \mathrm{NaOH}$ to achieve a final concentration of $0.25 \mathrm{M} \mathrm{NaOH}$, and then $0.967 \mathrm{M} \mathrm{NaMnO}_{4}$ stock solution was added to yield a $\mathrm{Mn}$ :Cr ratio of 1.0. The measured amounts of chromium present in each test item and the amount of permanganate added is shown in Table 2.6. Each test solution was agitated at the target temperature of $25^{\circ} \mathrm{C}$ or $45^{\circ} \mathrm{C}$ for 6 hours. Each reaction bottle was centrifuged for at least 5 minutes, and each supernate was decanted into a labeled and tared plastic bottle. The leached solids remaining in each caustic leachate bottle were washed by adding $0.01 \mathrm{M} \mathrm{NaOH}$ (in an equivalent amount to the leach solution) into each test container and agitated for at least 10 minutes. The wash solution was at ambient temperature. The sample was centrifuged for at least 5 minutes, and the supernate was decanted into the appropriate tared plastic bottle containing the previous supernate. The washing process was repeated for a second wash.

Table 2.6. Quantities of Chromium and Manganese Present in Test Items at Beginning of Oxidative Leaching of Simulated Tank Waste Solids

\begin{tabular}{cccccccc}
\hline Test & $\begin{array}{c}\text { AFA } \\
\text { target } \\
(\mathrm{mg} / \mathrm{L})\end{array}$ & $\begin{array}{c}\text { Initial Mass Cr } \\
\text { in Solids }(\mu \mathrm{g})\end{array}$ & $\begin{array}{c}\text { Initial Cr } \\
(\mathrm{moles})\end{array}$ & $\begin{array}{c}\text { Initial Mass } \\
\mathrm{Mn}(\mu \mathrm{g})\end{array}$ & $\begin{array}{c}\mathrm{MnO}^{-} \text {Added } \\
(\mathrm{moles})\end{array}$ & $\begin{array}{c}\text { Mass Mn } \\
\text { Added }(\mu \mathrm{g})\end{array}$ & $\begin{array}{c}\text { Cr:Mn } \\
\text { Malar } \\
\text { Ratio }\end{array}$ \\
\hline 1 & 175 & 540,000 & 0.010 & 1,100 & 0.011 & 610,000 & 0.95 \\
\hline 2 & 350 & 530,000 & 0.010 & 1,100 & 0.011 & 610,000 & 0.93 \\
\hline 3 & 350 & 570,000 & 0.011 & 930 & 0.011 & 610,000 & 0.99 \\
$4 \mathrm{a}$ & 700 & 570,000 & 0.011 & 2,000 & 0.011 & 610,000 & 1.00 \\
\hline $\mathrm{b}$ & 700 & 570,000 & 0.011 & 1,400 & 0.011 & 610,000 & 0.99 \\
$4 \mathrm{c}$ & 700 & 570,000 & 0.011 & 900 & 0.011 & 610,000 & 0.99 \\
\hline 5 & 350 & 580,000 & 0.011 & 3,500 & 0.011 & 610,000 & 1.00 \\
\hline 6 & 700 & 770,000 & 0.015 & {$[560]$} & 0.011 & 610,000 & 1.30 \\
\hline 7 & 350 & 560,000 & 0.011 & {$[380]$} & 0.011 & 610,000 & 0.98 \\
\hline $\mathrm{a}$ & 0 & 560,000 & 0.011 & {$[240]$} & 0.011 & 610,000 & 0.98 \\
\hline $8 \mathrm{~b}$ & 0 & 560,000 & 0.011 & {$[70]$} & 0.011 & 610,000 & 0.98 \\
\hline $8 \mathrm{c}$ & 0 & 550,000 & 0.011 & $<72$ & 0.011 & 610,000 & 0.96 \\
\hline 9 & 700 & 700,000 & 0.013 & $<60$ & 0.011 & 610,000 & 1.20 \\
\hline 10 & 700 & 550,000 & 0.011 & $<40$ & 0.011 & 610,000 & 0.95 \\
\hline
\end{tabular}

(a) Values in brackets [] are $\geq$ the method detection limit, but are $<$ the estimated quantitation limit, with errors likely to exceed $15 \%$.

After agitating each bottle containing supernate and washes to confirm that the contents were well mixed, an aliquot of sample from each bottle was removed and filtered through a $0.2-\mu \mathrm{m}$ syringe filter 
into a vial. The solution density was determined by measuring the weight of three $1 \mathrm{~mL}$ aliquots of these filtered solutions. An aliquot from each filtered solution was transferred into a tared and labeled $20 \mathrm{~mL}$ glass liquid scintillation counting (LSC) vial containing $9 \mathrm{~mL}$ of $1 \mathrm{M} \mathrm{HNO}_{3}$ for ICP and $\mathrm{Pu}$ (by AEA) analysis. Another aliquot from each filtered solution was submitted for hydroxide, TOC, and TIC analysis.

The centrifuged solids were dried to incipient dryness at $80^{\circ} \mathrm{C}$ and then dried at $105^{\circ} \mathrm{C}$ overnight. The solids were submitted for potassium hydroxide $(\mathrm{KOH})$ fusion, metals content by ICP-AES, Pu (by AEA), TIC, and TOC.

\subsection{Quality Assurance}

PNNL's QA program is based on requirements defined in DOE Order 414.1C, Quality Assurance and 10 CFR 830, Energy/Nuclear Safety Management, Subpart A-Quality Assurance Requirements (a.k.a. the Quality Rule). As of September 2008, PNNL has chosen to implement the following consensus standards in a graded approach:

- ASME NQA-1-2000, Quality Assurance Requirements for Nuclear Facility Applications, Part 1, Requirements for Quality Assurance Programs for Nuclear Facilities.

- ASME NQA-1-2000, Part II, Subpart 2.7, Quality Assurance Requirements for Computer Software for Nuclear Facility Applications.

- ASME NQA-1-2000, Part IV, Subpart 4.2, Graded Approach Application of Quality Assurance Requirements for Research and Development.

PNNL implements these requirements by integrating them into the laboratory's management systems and daily operating processes. The procedures necessary to implement the requirements are documented through PNNL's "How do I...?" (HDI). ${ }^{\text {(a) }}$

PNNL implemented the RPP-WTP quality requirements by performing work in accordance with the River Protection Project-Waste Treatment Plant Support Program (RPP-WTP) Quality Assurance Plan (RPP-WTP-QA-001, QAP). Work was performed to the quality requirements of NQA-1-1989 Part I, Basic and Supplementary Requirements, NQA-2a-1990, Part 2.7, and DOE/RW-0333P, Rev 13, Quality Assurance Requirements and Descriptions (QARD). These quality requirements are implemented through the River Protection Project-Waste Treatment Plant Support Program (RPP-WTP) Quality Assurance Manual (RPP-WTP-QA-003, QAM). The analytical requirements are implemented through RPP-WTP's Statement of Work (RPP-WTP-QA-005) with the RPL-ASO.

The quality assurance requirements of DOE/RW-0333P, Rev 13, Quality Assurance Requirements and Descriptions (QARD) and DOE Order 414.1C were not identified as a requirement for this work in the Test Specification.

\subsection{Conduct of Experimental and Analytical Work}

Experiments that were not method-specific were performed in accordance with PNNL's procedures QA-RPP-WTP-1101 "Scientific Investigations" and QA-RPP-WTP-1201 "Calibration Control System,"

(a) System for managing the delivery of laboratory-level policies, requirements, and procedures. 
verifying that sufficient data were taken with properly calibrated measuring and test equipment (M\&TE) to obtain quality results.

A test guidance, 53019-AFA-1 "Alkaline Oxidative Leaching of Cr from a Hanford Tank Waste Simulant" was used to describe the work to be performed. Operational aspects of this work were governed by procedure RPL-OP-001 and the applicable permits and supporting procedures referenced therein.

Reported hydroxide analyses were performed by RPL-ASO according to procedure RPG-CMC-228, Rev 1. No QC issues were associated with these data.

Solution metal concentrations (including uranium) were determined by ICP-OES according to procedure RPG-CMC-211. The controlling documents for these analyses were ASO-QAP-001 and RPP-WTP-QA-005, Rev 3. All QC checks were within the acceptance criteria.

Reported metals and uranium for the solids from oxidative leaching of the radioactive simulant were dissolved according to PNL-ALO-115 and analyzed by ICP-OES according to RPG-CMC-211. No QC issues were associated with these data.

Radionuclides were obtained for solids and prepared solutions. Solids were prepared according to PNL-ALO-115. Plutonium was measured according to RPG-CMC-496, Rev 0 and RPG-CMC-422, Rev 2. No QC issues were associated with these data.

Anions by IC were measured using PNL-ALO-212. Samples were prepared by bench dilution. There were no QC issues associated with these data.

TIC and TOC were determined using a hot persulfate method according to RPG-CMC-385 Rev 0. No QC issues were associated with these data.

Additional M\&TE that were used included clocks, programmable heater/stirrers, tachometers, thermocouple-meters, and balances. The clocks, tachometers, and programmable heater-stirrers were standard laboratory equipment for use as indicators only. The thermocouple-meter combination was calibrated by the PNNL Instrument Calibration Facility. The thermometers were calibrated June 2008. Balances are calibrated annually by a certified contractor, QC Services, Portland, Oregon. A balance performance check was conducted each day the balance was used.

\subsection{Internal Data Verification and Validation}

PNNL addressed internal verification and validation activities by conducting an independent technical review of the final data report in accordance with PNNL's procedure QA-RPP-WTP-604. This review verified that the reported results were traceable, that inferences and conclusions were soundly based, and the reported work satisfied the Test Plan objectives. This review procedure is part of PNNL's RPP-WTP Quality Assurance Manual. 


\subsection{Results and Discussion}

\subsection{Test Item Characterization}

The initial concentrations of elements of interest were determined after equilibrating the simulant tank waste slurries in $3 \mathrm{M} \mathrm{NaOH}$ containing the specified amounts of AFA. Amounts of key components in the radioactive simulant are shown in Table 3.1. These masses are the amounts of each component that were present in the approximately 3.2 grams of sample used in each test. Although no Mn was included in the simulant recipe, some of the samples tested positive for small amounts of Mn. These results show a wide variability and are believed to be either trace contaminants in the chemicals used for simulant or artifacts of the analytical method. The samples were prepared using a $\mathrm{KOH}-\mathrm{KNO}_{3}$ fusion in a nickel crucible, so nickel concentrations were not obtained for the solid samples. Nickel concentrations in the supernate were all below detection limits.

Table 3.1. Measured Amounts of Key Components in the Radioactive Simulant Solids Equilibrated with $3 \mathrm{M} \mathrm{NaOH}$ Before Heating for Caustic Leaching

\begin{tabular}{|c|c|c|c|c|c|c|c|}
\hline Test & $\begin{array}{l}\mathrm{Cr} \\
(\mu \mathrm{g})\end{array}$ & $\begin{array}{l}\mathrm{Fe} \\
(\mu \mathrm{g})\end{array}$ & $\begin{array}{c}\mathrm{Mn}^{(\mathrm{a})} \\
(\mu \mathrm{g})\end{array}$ & $\begin{array}{l}\mathrm{Ni}^{(\mathrm{b})} \\
(\mu \mathrm{g})\end{array}$ & $\begin{array}{c}\mathrm{U} \\
(\mu \mathrm{g})\end{array}$ & $\begin{array}{l}{ }^{239+240} \mathrm{Pu} \\
(\mu \mathrm{Ci})\end{array}$ & $\begin{array}{c}{ }^{238} \mathrm{Pu}+ \\
{ }^{241} \mathrm{Am} \\
(\mu \mathrm{Ci})\end{array}$ \\
\hline 1 & 540,000 & 750,000 & 5,000 & 30,000 & {$[9,100]$} & 63 & 1.3 \\
\hline 2 & 530,000 & 740,000 & 7,600 & 30,000 & {$[8,000]$} & 68 & 1.9 \\
\hline 3 & 570,000 & 800,000 & 4,900 & 30,000 & {$[4,100]$} & 63 & 1.3 \\
\hline $4 a$ & 570,000 & 770,000 & 11,000 & 30,000 & {$[8,900]$} & 77 & 1.9 \\
\hline $4 \mathrm{~b}$ & 570,000 & 760,000 & 6,700 & 30,000 & {$[9,300]$} & 69 & 1.7 \\
\hline $4 c$ & 570,000 & 790,000 & 5,300 & 30,000 & {$[6,600]$} & 68 & 1.8 \\
\hline 5 & 580,000 & 800,000 & 20,000 & 30,000 & {$[11,000]$} & 70 & 1.7 \\
\hline 6 & 770,000 & $1,000,000$ & [4200] & 30,000 & {$[18,000]$} & 92 & 2.5 \\
\hline 7 & 560,000 & 750,000 & [2300] & 30,000 & {$[7,600]$} & 68 & 1.7 \\
\hline $8 a$ & 560,000 & 750,000 & [1500] & 30,000 & {$[12,000]$} & 73 & 2.3 \\
\hline $8 b$ & 560,000 & 740,000 & {$[440]$} & 30,000 & {$[14,000]$} & 69 & 1.7 \\
\hline $8 \mathrm{c}$ & 550,000 & 720,000 & $<690$ & 30,000 & {$[10,000]$} & 67 & 1.8 \\
\hline 9 & 700,000 & 930,000 & $<370$ & 30,000 & {$[22,000]$} & 79 & 1.9 \\
\hline 10 & 550,000 & 720,000 & $<220$ & 30,000 & {$[11,000]$} & 69 & 2.0 \\
\hline Average & 580,000 & 790,000 & 5,000 & - & 11,000 & 71 & 1.8 \\
\hline Stdev & 65,000 & 84,000 & 680 & - & 4,700 & 7 & 0.3 \\
\hline RSD & $11 \%$ & $11 \%$ & $120 \%$ & - & $43 \%$ & $18 \%$ & $17 \%$ \\
\hline \multicolumn{8}{|c|}{$\begin{array}{l}\text { (a) Values in brackets [] are } \geq \text { the method detection limit, but are }<\text { the estimated quantitation limit, with errors } \\
\text { likely to exceed } 15 \% .\end{array}$} \\
\hline
\end{tabular}

The equilibrated leach solution for each slurry was filtered and analyzed for key components. For all of the leach solutions, the nickel concentration was below the instrument detection limit. Values for analytes are shown in Table 3.2. These quantities represent the total amount of each component in each test item containing approximately $125 \mathrm{~mL}$ of test slurry and leachate. 
Table 3.2. Initial Amounts of Key Components in Equilibrated Leachate Solution Before Heating for Caustic Leaching ${ }^{(a)}$

\begin{tabular}{cccccccc}
\hline Test & $\begin{array}{c}\mathrm{Cr} \\
(\mu \mathrm{g})\end{array}$ & $\begin{array}{c}\mathrm{Fe} \\
(\mu \mathrm{g})\end{array}$ & $\begin{array}{c}\mathrm{Mn} \\
(\mu \mathrm{g})\end{array}$ & $\begin{array}{c}\mathrm{Ni} \\
(\mu \mathrm{g})\end{array}$ & $\begin{array}{c}\mathrm{U} \\
(\mu \mathrm{g})\end{array}$ & $\begin{array}{c}{ }^{239+240} \mathrm{Pu} \\
(\mu \mathrm{Ci})\end{array}$ & $\begin{array}{c}{ }^{238} \mathrm{Pu}+{ }^{241} \mathrm{Am} \\
(\mu \mathrm{Ci})\end{array}$ \\
\hline 1 & 2,300 & {$[16]$} & $<2.7$ & $<68$ & {$[2,900]$} & $4.5 \mathrm{E}-2$ & $8.9 \mathrm{E}-4$ \\
2 & 2,200 & {$[28]$} & $<2.6$ & $<67$ & {$[2,500]$} & $4.9 \mathrm{E}-2$ & $9.6 \mathrm{E}-4$ \\
3 & 2,100 & {$[34]$} & $<2.6$ & $<67$ & {$[2,900]$} & $2.5 \mathrm{E}-1$ & $4.9 \mathrm{E}-3$ \\
$4 \mathrm{a}$ & 2,200 & {$[22]$} & $<2.6$ & $<67$ & {$[2,800]$} & $4.5 \mathrm{E}-2$ & $7.8 \mathrm{E}-4$ \\
$4 \mathrm{~b}$ & 2,200 & {$[21]$} & $<2.6$ & $<67$ & {$[2,800]$} & $5.0 \mathrm{E}-2$ & $9.1 \mathrm{E}-4$ \\
$4 \mathrm{c}$ & 2,100 & {$[33]$} & $<2.6$ & $<67$ & {$[2,800]$} & $9.3 \mathrm{E}-2$ & $1.7 \mathrm{E}-3$ \\
5 & 2,100 & $<1.3$ & $<2.6$ & $<67$ & {$[2,400]$} & $5.1 \mathrm{E}-2$ & $9.1 \mathrm{E}-4$ \\
6 & 2,200 & {$[18]$} & $<2.6$ & $<67$ & {$[2,500]$} & $5.5 \mathrm{E}-2$ & $1.1 \mathrm{E}-3$ \\
7 & 2,200 & {$[18]$} & $<2.6$ & $<67$ & {$[2,800]$} & $5.3 \mathrm{E}-2$ & $9.6 \mathrm{E}-4$ \\
$8 \mathrm{a}$ & 2,200 & {$[20]$} & $<2.6$ & $<68$ & {$[3,000]$} & $5.5 \mathrm{E}-2$ & $9.8 \mathrm{E}-4$ \\
$8 \mathrm{~b}$ & 2,200 & {$[21]$} & $<2.6$ & $<67$ & {$[3,000]$} & $5.1 \mathrm{E}-2$ & $9.6 \mathrm{E}-4$ \\
$8 \mathrm{c}$ & 2,200 & {$[18]$} & $<2.6$ & $<67$ & {$[2,900]$} & $5.3 \mathrm{E}-2$ & $9.0 \mathrm{E}-4$ \\
\hline 9 & 2,200 & $<1.3$ & $<2.6$ & $<68$ & {$[3,200]$} & $4.9 \mathrm{E}-2$ & $8.4 \mathrm{E}-4$ \\
10 & 2,200 & {$[26]$} & $<2.6$ & $<67$ & {$[3,000]$} & $5.1 \mathrm{E}-2$ & $1.0 \mathrm{E}-3$ \\
\hline Average & 2,200 & 20 & & & 2,800 & $6.8 \mathrm{E}-2$ & $1.3 \mathrm{E}-3$ \\
Stdev & 53 & 10 & & & 240 & $5.5 \mathrm{E}-2$ & $1.1 \mathrm{E}-3$ \\
RSD & $2 \%$ & $48 \%$ & & & $8 \%$ & $80 \%$ & $84 \%$ \\
\hline
\end{tabular}

(a) Values in brackets [] are $\geq$ the method detection limit, but are $<$ the estimated quantitation limit, with errors likely to exceed $15 \%$.

Two triplicate samples (total six test items) were tested to determine variability in the method. These triplicates were test items $4 \mathrm{a}-\mathrm{c}$ that contained AFA at the $700 \mathrm{ppm}$ level and items $8 \mathrm{a}-\mathrm{c}$ that contained no AFA. Results, averages, standard deviations, and relative standard deviations for each of the elements of interest in the initial test item solids equilibrated with $3 \mathrm{M} \mathrm{NaOH}$ are shown in Table 3.3. 
Table 3.3. Statistical Analysis of Triplicate Test Items at Two AFA Concentration Levels in the Simulant

\begin{tabular}{|c|c|c|c|c|c|c|c|c|}
\hline & & \multicolumn{7}{|c|}{ Quantities Measured in Initial Supernate } \\
\hline $\begin{array}{c}\text { AFA } \\
\text { Level } \\
(\mathrm{mg} / \mathrm{L})\end{array}$ & & $\begin{array}{c}\mathrm{Cr} \\
(\mu \mathrm{g})\end{array}$ & $\begin{array}{c}\mathrm{Fe} \\
(\mu \mathrm{g})\end{array}$ & $\begin{array}{l}\mathrm{Mn} \\
(\mu \mathrm{g})\end{array}$ & $\begin{array}{c}\mathrm{U} \\
(\mu \mathrm{g})\end{array}$ & $\begin{array}{c}\mathrm{Zn} \\
(\mu \mathrm{g})\end{array}$ & $\begin{array}{c}{ }^{239+240} \mathrm{Pu} \\
(\mu \mathrm{Ci})\end{array}$ & $\begin{array}{c}{ }^{238} \mathrm{Pu}+{ }^{241} \mathrm{Am} \\
(\mu \mathrm{Ci})\end{array}$ \\
\hline \multirow{3}{*}{0} & Average & 2,300 & 20 & 0 & 3,094 & 368 & $5.3 \mathrm{E}-02$ & $9.4 \mathrm{E}-04$ \\
\hline & Stdev & 83 & 1 & 0 & 158 & 3 & $2.2 \mathrm{E}-03$ & 4.3E-05 \\
\hline & RSD & $3.6 \%$ & $5.6 \%$ & $0.0 \%$ & $5.1 \%$ & $0.8 \%$ & $4.2 \%$ & $4.5 \%$ \\
\hline \multirow{3}{*}{700} & Average & 2,100 & 25 & 0 & 2,707 & 317 & $6.2 \mathrm{E}-02$ & $1.1 \mathrm{E}-03$ \\
\hline & Stdev & 100 & 6 & 0 & 82 & 45 & $2.6 \mathrm{E}-02$ & 4.8E-04 \\
\hline & RSD & $4.8 \%$ & $23.8 \%$ & $0.0 \%$ & $4.8 \%$ & $14.2 \%$ & $42.5 \%$ & $43.0 \%$ \\
\hline & & \multicolumn{7}{|c|}{ Quantities Measured in Initial Solids } \\
\hline $\begin{array}{c}\text { AFA Level } \\
(\mathrm{mg} / \mathrm{L})\end{array}$ & & $\begin{array}{c}\mathrm{Cr} \\
(\mu \mathrm{g})\end{array}$ & $\begin{array}{c}\mathrm{Fe} \\
(\mu \mathrm{g})\end{array}$ & $\begin{array}{l}\mathrm{Mn} \\
(\mu \mathrm{g})\end{array}$ & $\begin{array}{c}\mathrm{U} \\
(\mu \mathrm{g})\end{array}$ & $\begin{array}{c}\mathrm{Zn} \\
(\mu \mathrm{g})\end{array}$ & $\begin{array}{c}{ }^{239+240} \mathrm{Pu} \\
(\mu \mathrm{Ci})\end{array}$ & $\begin{array}{c}{ }^{238} \mathrm{Pu}+{ }^{241} \mathrm{Am} \\
(\mu \mathrm{Ci})\end{array}$ \\
\hline \multirow{3}{*}{0} & Average & 560,000 & 735,639 & 126 & 19,000 & 6,800 & 70 & 1.9 \\
\hline & Stdev & 7,200 & 10,575 & 95 & 1,900 & 670 & 3.2 & 0.34 \\
\hline & RSD & $1.3 \%$ & $1.4 \%$ & $75.3 \%$ & $10 \%$ & $9.7 \%$ & $4.5 \%$ & $18 \%$ \\
\hline \multirow{3}{*}{700} & Average & 570,000 & 770,000 & 1,400 & 12,000 & 7,200 & 71 & 1.8 \\
\hline & Stdev & 3,000 & 15,000 & 540 & 2,100 & 390 & 0.11 & 0.11 \\
\hline & RSD & $0.5 \%$ & $1.9 \%$ & $37 \%$ & $17 \%$ & $5.5 \%$ & $7.0 \%$ & $5.9 \%$ \\
\hline
\end{tabular}

Samples of the filtered supernate were collected after the simulant slurry had been equilibrated with the $3 \mathrm{M} \mathrm{NaOH}$ leachate, but before the simulant was heated for the caustic-leach. A separate aliquot of the same initial equilibrated leachate solution was submitted for anions, hydroxide and TIC/TOC analysis. The results of the supernate analyses are shown in Table 3.4. The hydroxide concentration in Test 3 was high because of an error during initial leachate preparation. 
Table 3.4. Anions, Hydroxide, Inorganic and Organic Carbon in Supernate Before Heating for Caustic-Leach

\begin{tabular}{cccccc}
\hline Test & $\mathrm{Cl}^{-}, \mathrm{ppm}$ & $\mathrm{NO}_{3}{ }^{-}, \mathrm{ppm}$ & $\mathrm{OH}^{-}, \mathrm{M}$ & $\mathrm{TIC}, \mu \mathrm{g} \mathrm{C} / \mathrm{mL}$ & $\mathrm{TOC}, \mu \mathrm{g} \mathrm{C} / \mathrm{mL}$ \\
\hline 1 & 1,500 & 31,000 & 2.55 & 710 & 710 \\
2 & 1,500 & 31,000 & 2.55 & 710 & 770 \\
3 & 2,100 & 25,000 & 4.59 & 1900 & $<560$ \\
$4 \mathrm{a}$ & 1,400 & 31,000 & 3.06 & 710 & 1,500 \\
$4 \mathrm{~b}$ & 1,400 & 30,000 & 2.55 & 610 & $<560$ \\
$4 \mathrm{c}$ & 1,700 & 29,000 & 3.57 & 610 & $<560$ \\
5 & 1,500 & 31,000 & 3.06 & 920 & $<560$ \\
6 & 1,500 & 31,000 & 2.55 & 1,000 & $<560$ \\
7 & 1,500 & 31,000 & 3.06 & 1,100 & $<1,600$ \\
$8 \mathrm{a}$ & 1,500 & 31,000 & 3.06 & 510 & $<1,600$ \\
$8 \mathrm{~b}$ & 1,500 & 31,000 & 3.06 & 560 & $<1,600$ \\
$8 \mathrm{c}$ & 1,700 & 31,000 & 3.06 & 870 & $<1,600$ \\
9 & 1,500 & 31,000 & 3.06 & 410 & $<1,600$ \\
10 & 1,500 & 31,000 & 3.06 & 260 & $<1,600$ \\
\hline
\end{tabular}

Carbon was measured as TIC and TOC with the results reported in Table 3.5. Organic carbon concentration was below the detection limit of the analytical method.

Table 3.5. Inorganic and Organic Carbon in Solids Before Caustic-Leach

\begin{tabular}{ccc}
\hline Test & TIC, $\mu \mathrm{g}$ & TOC, $\mu \mathrm{g}$ \\
\hline 1 & 63,000 & $<5,000$ \\
2 & 61,000 & $<3,600$ \\
3 & 80,000 & $<5,100$ \\
$4 \mathrm{a}$ & 51,000 & $<4,100$ \\
$4 \mathrm{~b}$ & 41,000 & 20,000 \\
$4 \mathrm{c}$ & 58,000 & $<4,700$ \\
5 & 56,000 & $<4,600$ \\
6 & 220,000 & $<200$ \\
7 & 320,000 & $<11,000$ \\
$8 \mathrm{a}$ & 200,000 & $<7,700$ \\
$8 \mathrm{~b}$ & 61,000 & $<8,700$ \\
$8 \mathrm{c}$ & 53,000 & $<7,400$ \\
9 & 230,000 & $<24,000$ \\
10 & 120,000 & $<12,000$ \\
\hline
\end{tabular}

Some of the test items equilibrated with $3 \mathrm{M} \mathrm{NaOH}$ may be seen in Figure 3.1. The solids in this image are not completely settled. 


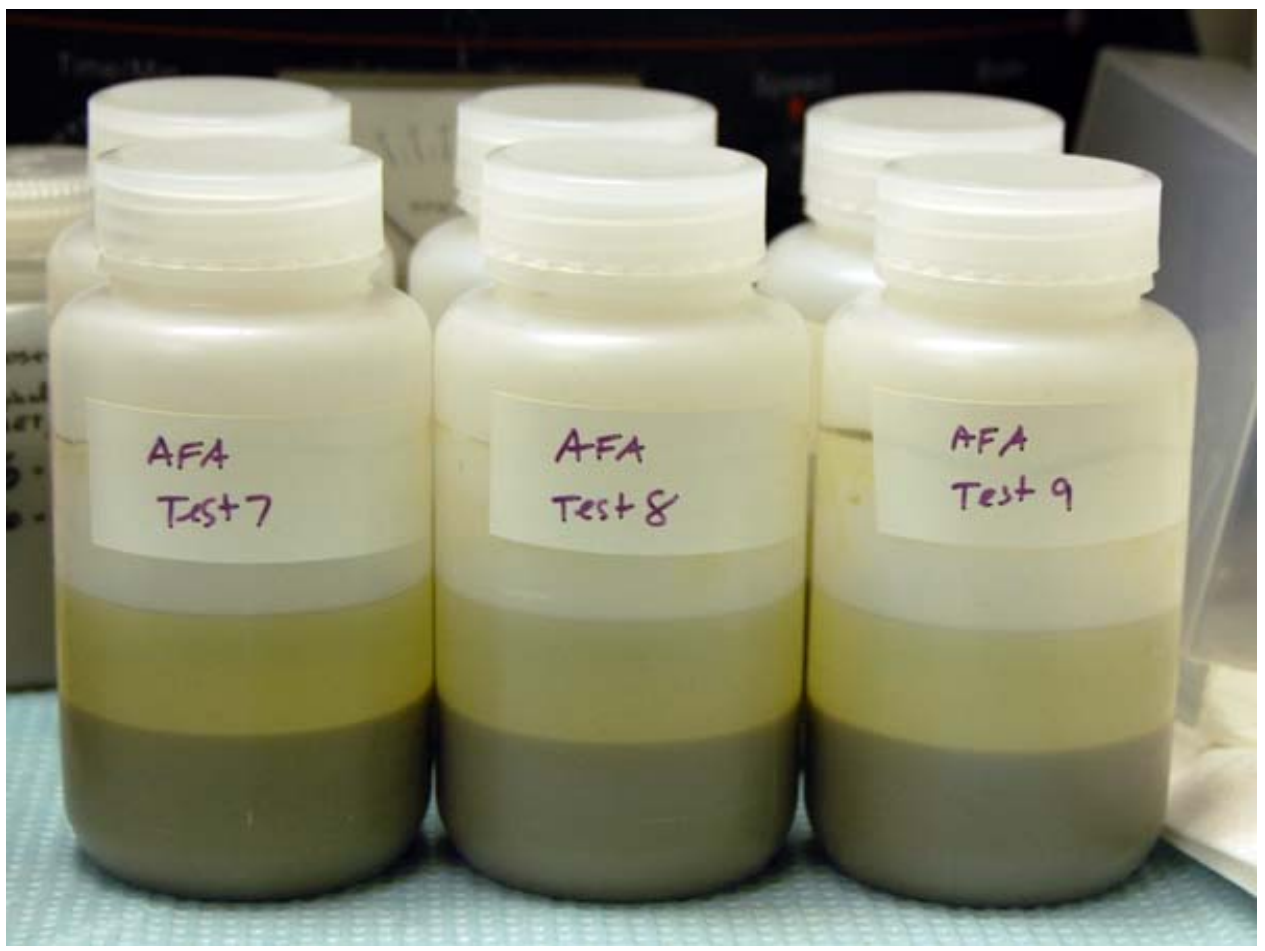

Figure 3.1. Some of the Test Items Equilibrated with $3 \mathrm{M} \mathrm{NaOH}$ Before Heating for Caustic-Leach

\subsection{Caustic-Leach Results}

Table 3.6 shows the quantities of key components that partition to the caustic leachate after heating the sample slurry-leachate mixtures to $85 \pm 5^{\circ} \mathrm{C}$ for 8 hours. These quantities are based on the analysis of the supernate solution combined with the wash solutions. The uranium values in the leachate are unrealistically high compared to the initial solids uranium value. The initial solids analysis for uranium returned a value that averaged $20 \%$ of the calculated preparation concentration. As will be seen later for the final solids analysis, the final uranium value is in line with expected values based on the simulant preparation. It must be concluded that there was a strong bias in either the sample collection or the sample analysis for the initial value of uranium in the slurry solids.

Manganese and nickel were not detected in any of the initial equilibrated or the caustic leachate solutions. The detection limit for the method combined with the leachate volumes are included in Table 3.6 and have had the sample dilution factors applied. 
Table 3.6. Amounts of Key Components in Caustic Leachate

\begin{tabular}{|c|c|c|c|c|c|c|c|c|}
\hline Test & $\begin{array}{c}\mathrm{Cr} \\
(\mu \mathrm{g})\end{array}$ & $\begin{array}{l}\mathrm{Fe}^{(\mathrm{a})} \\
(\mu \mathrm{g})\end{array}$ & $\begin{array}{l}\mathrm{Mn} \\
(\mu \mathrm{g})\end{array}$ & $\begin{array}{c}\mathrm{Ni} \\
(\mu \mathrm{g})\end{array}$ & $\begin{array}{c}\mathrm{U} \\
(\mu \mathrm{g})\end{array}$ & $\begin{array}{c}\mathrm{Zn} \\
(\mu \mathrm{g})\end{array}$ & $\begin{array}{c}{ }^{239+240} \mathrm{Pu} \\
(\mu \mathrm{Ci})\end{array}$ & $\begin{array}{c}{ }^{238} \mathrm{Pu}+ \\
{ }^{241} \mathrm{Am} \\
(\mu \mathrm{Ci})\end{array}$ \\
\hline 1 & 4,500 & {$[160]$} & $<4.9$ & $<130$ & {$[3,200]$} & {$[930]$} & $3.6 \mathrm{E}-03$ & $1.1 \mathrm{E}-04$ \\
\hline 2 & 4,900 & [83] & $<5.0$ & $<130$ & {$[3,500]$} & {$[1,000]$} & $3.8 \mathrm{E}-03$ & $1.0 \mathrm{E}-04$ \\
\hline 3 & 4,900 & [81] & $<4.9$ & $<130$ & {$[4,400]$} & {$[590]$} & $5.8 \mathrm{E}-03$ & $1.1 \mathrm{E}-04$ \\
\hline $4 a$ & 3,700 & [49] & $<5.4$ & $<140$ & {$[4,400]$} & [790] & $6.0 \mathrm{E}-03$ & $1.4 \mathrm{E}-04$ \\
\hline $4 b$ & 3,100 & [52] & $<4.6$ & $<120$ & {$[3,000]$} & [590] & 4.3E-03 & $1.1 \mathrm{E}-04$ \\
\hline $4 c$ & 4,100 & [62] & $<4.9$ & $<130$ & {$[4,200]$} & [640] & $6.8 \mathrm{E}-03$ & $9.9 \mathrm{E}-05$ \\
\hline 5 & 4,300 & [76] & $<4.9$ & $<130$ & {$[3,500]$} & [790] & 4.3E-03 & $1.2 \mathrm{E}-04$ \\
\hline 6 & 4,300 & [67] & $<4.9$ & $<130$ & {$[3,500]$} & [770] & $3.6 \mathrm{E}-03$ & 8.1E-05 \\
\hline 7 & 2,800 & [53] & $<4.4$ & $<110$ & {$[3,700]$} & [680] & $6.4 \mathrm{E}-03$ & 9.9E-05 \\
\hline $8 a$ & 3,200 & [82] & $<5.0$ & $<130$ & {$[4,000]$} & [870] & $6.0 \mathrm{E}-03$ & $1.2 \mathrm{E}-04$ \\
\hline $8 b$ & 3,800 & [54] & $<4.5$ & $<110$ & {$[5,400]$} & [450] & $4.4 \mathrm{E}-03$ & 6.3E-05 \\
\hline $8 \mathrm{c}$ & 4,000 & $<23$ & $<4.7$ & $<120$ & {$[3,100]$} & [420] & $3.3 \mathrm{E}-03$ & 5.7E-05 \\
\hline 9 & 4,300 & [82] & $<4.2$ & $<110$ & {$[3,600]$} & [740] & $3.5 \mathrm{E}-03$ & $6.1 \mathrm{E}-05$ \\
\hline 10 & 2,800 & [59] & $<4.7$ & $<120$ & {$[3,800]$} & [630] & $1.0 \mathrm{E}-02$ & $1.7 \mathrm{E}-04$ \\
\hline
\end{tabular}

(a) Values in brackets [] are $\geq$ the method detection limit, but are $<$ the estimated quantitation limit, with errors likely to exceed $15 \%$.

The fractions of each key element removed by the caustic-leach of the simulant tank waste are shown in Figure 3.2. These results are from AEA, which cannot distinguish between ${ }^{238} \mathrm{Pu}$ and ${ }^{241} \mathrm{Am}$, so the results are reported together. Caustic leaching removed less than $1 \%$ of all elements with the exceptions of uranium and zinc. A second graph of the elements in the lower 1\% range is shown in Figure 3.3 with the scale expanded and converted to a logarithmic scale. Manganese and nickel concentrations are not shown in either figure because their concentrations were below the method detection limit. 


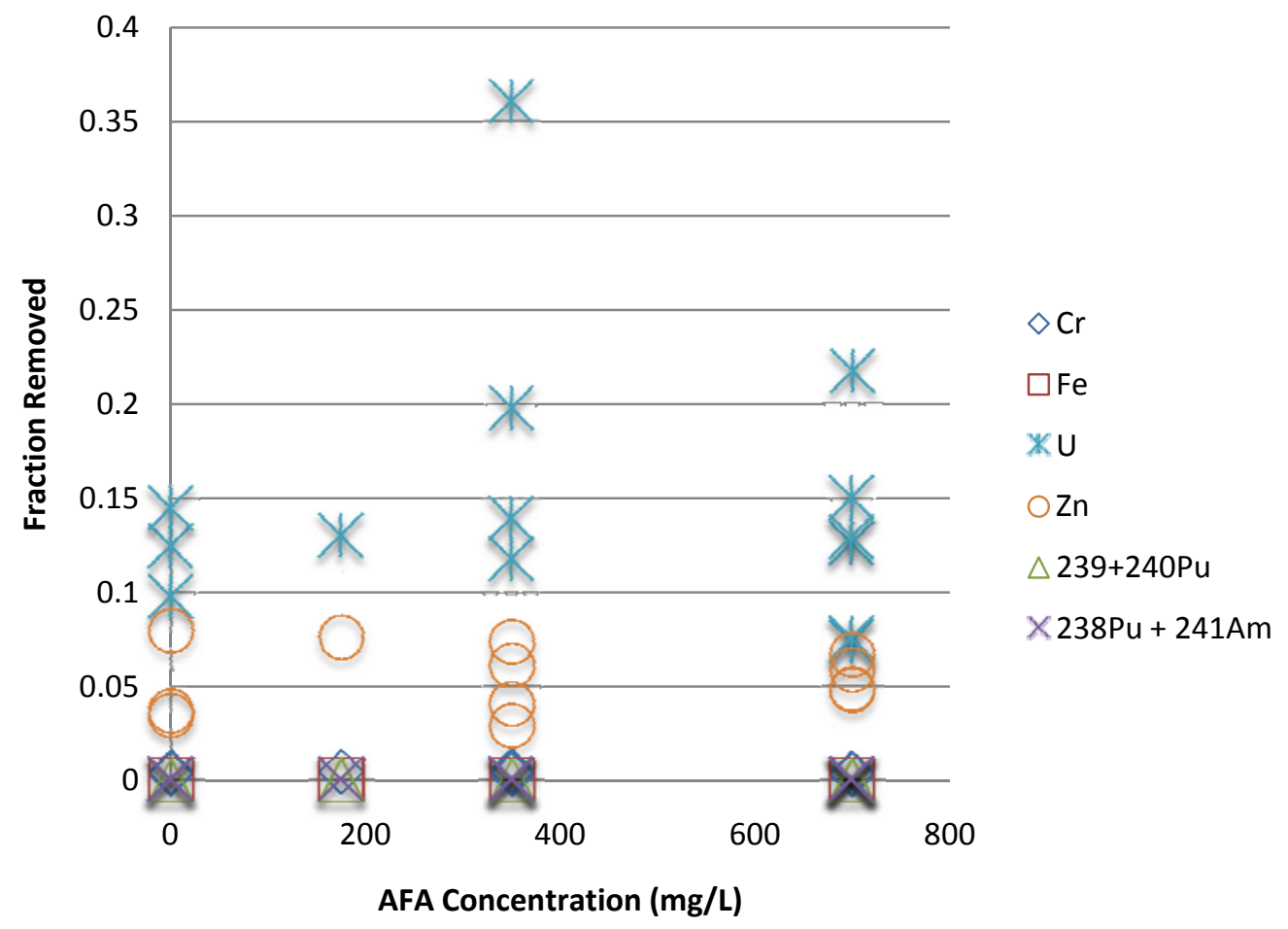

Figure 3.2. Impact of AFA Concentration on Key Elements During Caustic Leaching

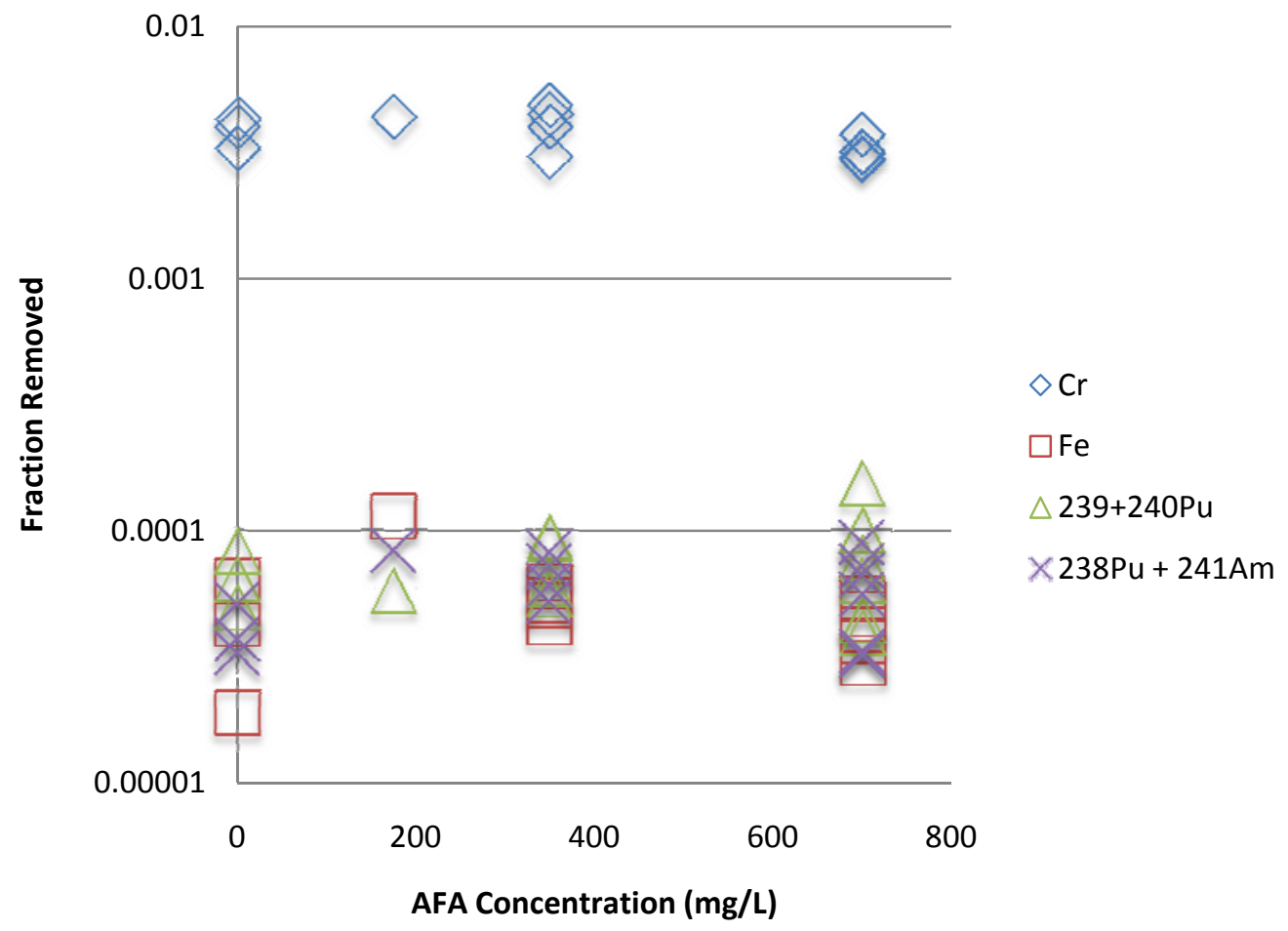

Figure 3.3. Expanded Caustic-Leach Results 


\subsection{Oxidative-Leach Results}

\subsubsection{Chromium Results}

Removal of chromium from simulated tank sludge by oxidative leaching resulted in 83 to $97 \%$ of initial chromium being removed as seen in Table 3.7. These values are based on analysis of washed and dried solids.

Table 3.7. Chromium Removal from Simulated Tank Sludge by Oxidative Leaching

\begin{tabular}{rccccc}
\hline Test & Initial Cr $(\mu \mathrm{g} / \mathrm{g})$ & $\begin{array}{c}\text { Initial Total Cr } \\
(\mu \mathrm{g})\end{array}$ & $\begin{array}{c}\text { Final Cr } \\
(\mu \mathrm{g} / \mathrm{g})\end{array}$ & $\begin{array}{r}\text { Final Total Cr } \\
(\mu \mathrm{g})\end{array}$ & $\begin{array}{c}\text { Fraction Cr } \\
\text { Removed }\end{array}$ \\
\hline 1 & 120,000 & 540,000 & 29,000 & 90,000 & 0.83 \\
2 & 79,000 & 530,000 & 37,000 & 110,000 & 0.79 \\
3 & 110,000 & 570,000 & 22,000 & 65,000 & 0.89 \\
$4 \mathrm{a}$ & 110,000 & 570,000 & 23,000 & 68,000 & 0.88 \\
$4 \mathrm{~b}$ & 120,000 & 570,000 & 27,000 & 81,000 & 0.86 \\
$4 \mathrm{c}$ & 97,000 & 570,000 & 8,800 & 26,000 & 0.95 \\
5 & 100,000 & 580,000 & 6,300 & 19,000 & 0.97 \\
6 & 100,000 & 770,000 & 8,000 & 24,000 & 0.97 \\
7 & 92,000 & 560,000 & 8,700 & 27,000 & 0.95 \\
$8 \mathrm{a}$ & 86,000 & 560,000 & 7,800 & 24,000 & 0.96 \\
$8 \mathrm{~b}$ & 88,000 & 560,000 & 8,800 & 27,000 & 0.95 \\
$8 \mathrm{c}$ & 57,000 & 550,000 & 7,200 & 22,000 & 0.96 \\
9 & 110,000 & 700,000 & 10,000 & 31,000 & 0.96 \\
10 & 99,000 & 550,000 & 6,700 & 21,000 & 0.96 \\
\hline
\end{tabular}

It should be noted that, although most of the chromium is leached from the waste, the overall mass of waste does not decrease because $\mathrm{MnO}_{2}$ replaces the chromium in the solids.

Evaluation of the chromium removal from the solids as a function of AFA concentration is summarized in Table 3.8 and the fraction chromium removed as a function of AFA concentration is shown in Figure 3.4. A least square fit of the data at $25^{\circ} \mathrm{C}$ yields $\mathrm{y}=-3 \mathrm{E}-05 \mathrm{x}+0.915$ with $\mathrm{R}^{2}=0.0275$ and at $45^{\circ} \mathrm{C}$ yields $\mathrm{y}=8 \mathrm{E}-06 \mathrm{x}+0.9565$ with $\mathrm{R}^{2}=0.0391$. These data show no correlation between the concentration of AFA and the effectiveness of the oxidative leaching for removal of chromium from the simulated tank sludge.

The concentration of chromium in the solids initially present in the simulated tank waste and the amount of chromium remaining after oxidative leaching is shown in Figure 3.5 for the $25^{\circ} \mathrm{C}$ tests and in Figure 3.6 for the $45^{\circ} \mathrm{C}$ tests. 
Table 3.8. Summary of Cr Removal by Oxidative-Leach Tests

\begin{tabular}{|c|c|c|c|c|c|c|}
\hline Temperature & $\begin{array}{c}\text { AFA } \\
\text { Added, } \\
\text { mg/L }\end{array}$ & $\begin{array}{l}\text { Fraction } \\
\text { Cr } \\
\text { Removed }\end{array}$ & $\begin{array}{c}\text { Data } \\
\text { Points }\end{array}$ & Average & Stdev & RSD \\
\hline $25^{\circ} \mathrm{C}$ & 0 & 0.95 & & & & \\
\hline $25^{\circ} \mathrm{C}$ & 0 & 0.96 & & & & \\
\hline $25^{\circ} \mathrm{C}$ & 0 & 0.96 & 3@25,0 & 0.96 & 0.0042 & $0.44 \%$ \\
\hline $25^{\circ} \mathrm{C}$ & 175 & 0.83 & $1 @ 25,175$ & 0.83 & NA & NA \\
\hline $25^{\circ} \mathrm{C}$ & 350 & 0.79 & \multirow{2}{*}{$\begin{array}{c}2 @ 25, \\
350\end{array}$} & & & \\
\hline $25^{\circ} \mathrm{C}$ & 350 & 0.89 & & 0.84 & 0.066 & $7.9 \%$ \\
\hline $25^{\circ} \mathrm{C}$ & 700 & 0.86 & \multirow{4}{*}{$\begin{array}{c}4 @ 25, \\
700\end{array}$} & & & \\
\hline $25^{\circ} \mathrm{C}$ & 700 & 0.88 & & & & \\
\hline $25^{\circ} \mathrm{C}$ & 700 & 0.95 & & & & \\
\hline $25^{\circ} \mathrm{C}$ & 700 & 0.96 & & 0.91 & 0.052 & $5.7 \%$ \\
\hline $45^{\circ} \mathrm{C}$ & 350 & 0.95 & \multirow{2}{*}{$\begin{array}{c}2 @ 45, \\
350\end{array}$} & & & \\
\hline $45^{\circ} \mathrm{C}$ & 350 & 0.97 & & 0.96 & 0.011 & $1.1 \%$ \\
\hline $45^{\circ} \mathrm{C}$ & 700 & 0.96 & \multirow{2}{*}{$\begin{array}{c}2 @ 45 \\
700\end{array}$} & & & \\
\hline $45^{\circ} \mathrm{C}$ & 700 & 0.97 & & 0.96 & 0.0093 & $0.96 \%$ \\
\hline $\mathrm{NA}=\operatorname{Not} \mathrm{Ap}$ & cable & & & & & \\
\hline
\end{tabular}

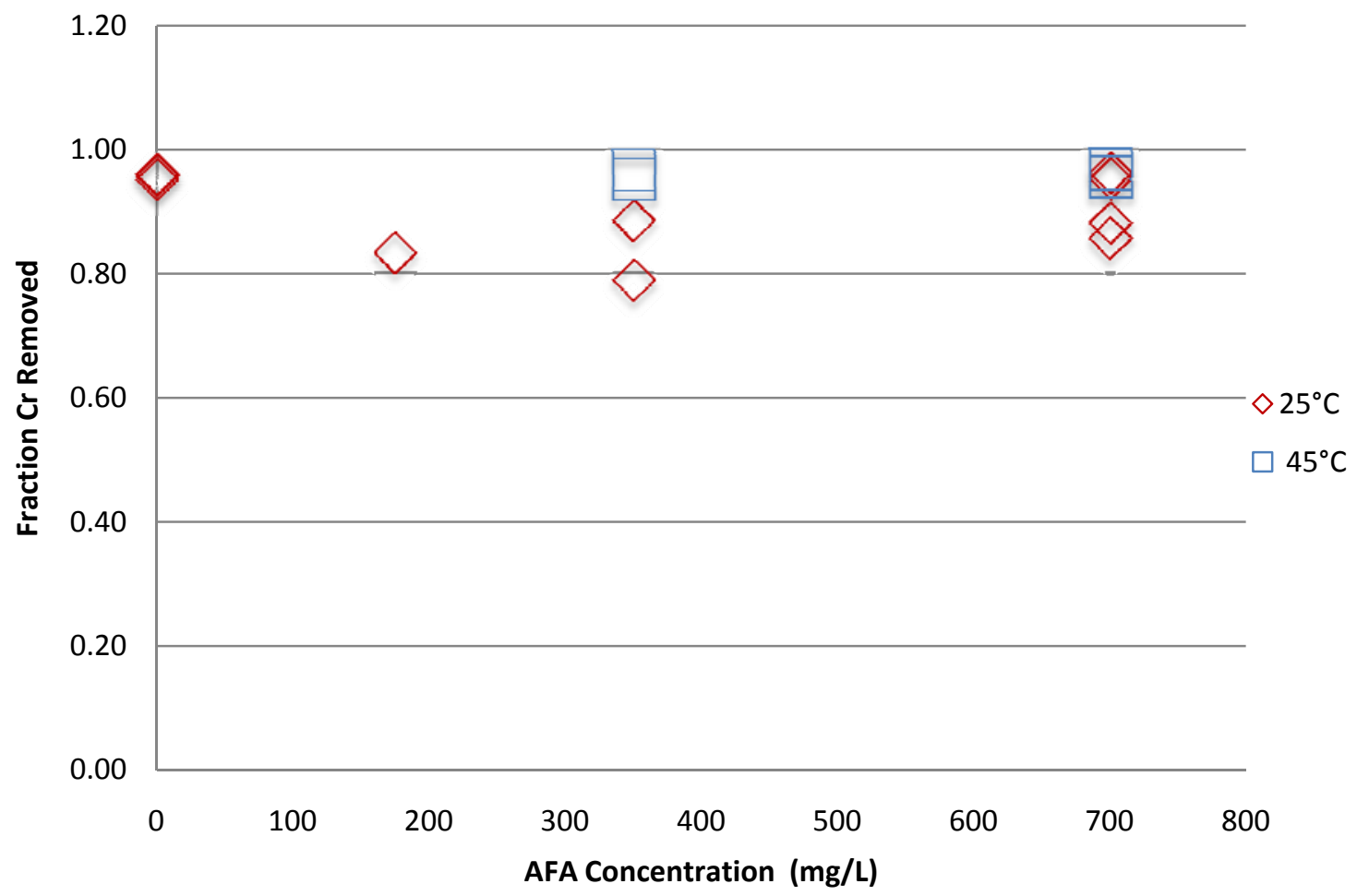

Figure 3.4. Chromium Removed from Simulated Tank Sludge by Oxidative Leaching with Permanganate 


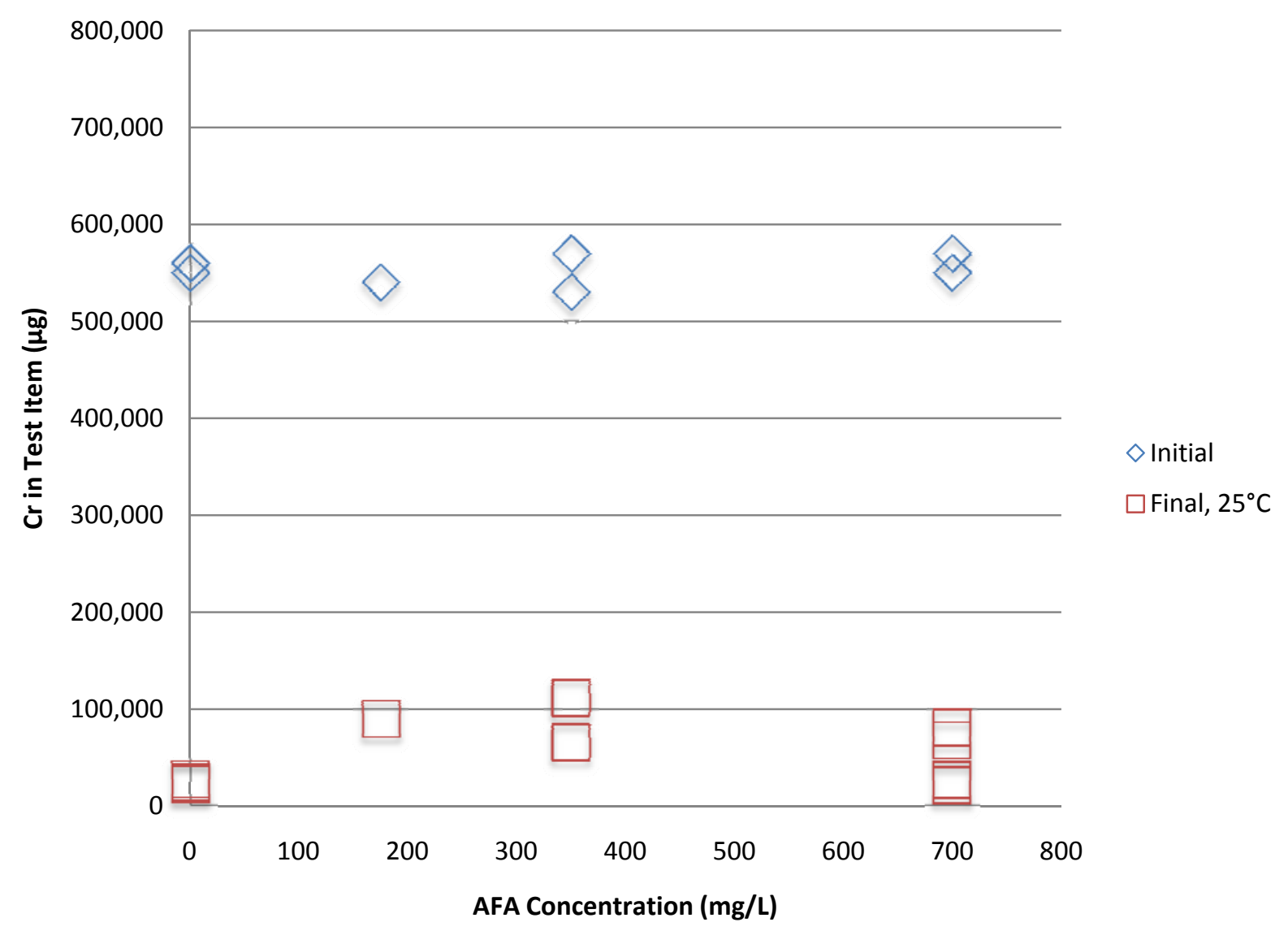

Figure 3.5. Quantity of Chromium in the Solids Before Oxidative Leaching (Initial) and After Oxidative Leaching (Final) at $25^{\circ} \mathrm{C}$ 


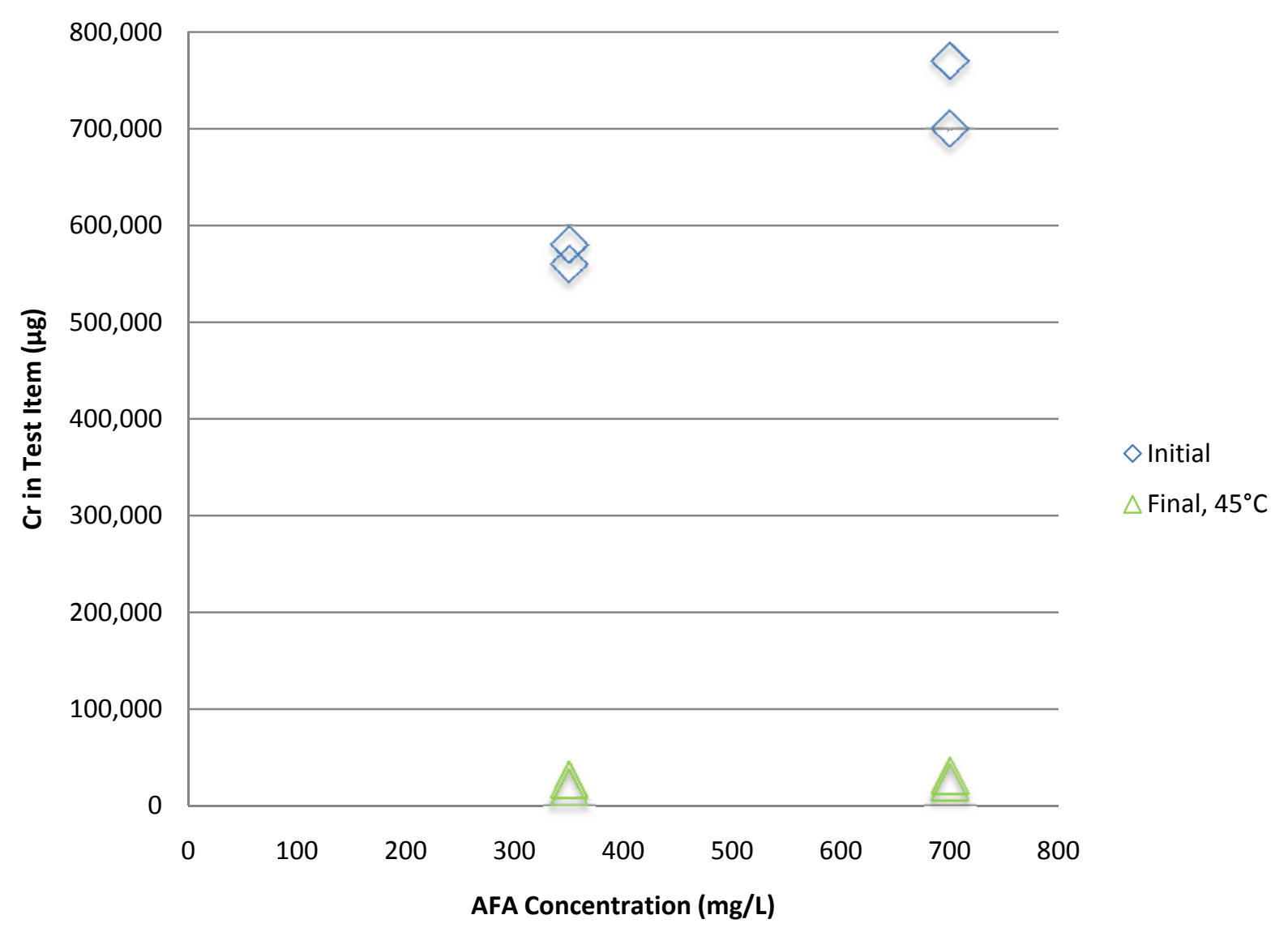

Figure 3.6. Quantity of Chromium in the Solids Before Oxidative Leaching (Initial) and After Oxidative Leaching (Final) at $45^{\circ} \mathrm{C}$

\subsubsection{Iron Results}

Removal of iron from simulated tank sludge by oxidative leaching resulted in $0.0032 \%$ to $0.026 \%$ of initial iron being removed as seen in Table 3.9. These values are based on analysis of leachate solution compared to washed and dried residual solids. 
Table 3.9. Iron Removal from Simulated Tank Sludge by Oxidative Leaching

\begin{tabular}{rccccc}
\hline Test & Initial Fe $(\mu \mathrm{g} / \mathrm{g})$ & $\begin{array}{c}\text { Initial Total Fe } \\
(\mu \mathrm{g})\end{array}$ & $\begin{array}{c}\text { Final Fe } \\
(\mu \mathrm{g} / \mathrm{g})\end{array}$ & $\begin{array}{c}\text { Final Total Fe } \\
(\mu \mathrm{g})\end{array}$ & $\begin{array}{c}\text { Fraction Fe } \\
\text { Removed }\end{array}$ \\
\hline 1 & 160,000 & 750,000 & 260,000 & 790,000 & 0.000060 \\
2 & 110,000 & 740,000 & 230,000 & 680,000 & 0.000086 \\
\hline 3 & 150,000 & 800,000 & 250,000 & 760,000 & 0.000092 \\
$4 \mathrm{a}$ & 140,000 & 770,000 & 280,000 & 830,000 & 0.000061 \\
$4 \mathrm{~b}$ & 160,000 & 760,000 & 240,000 & 740,000 & 0.000062 \\
$4 \mathrm{c}$ & 140,000 & 790,000 & 250,000 & 760,000 & 0.000032 \\
5 & 150,000 & 800,000 & 260,000 & 790,000 & 0.000091 \\
6 & 140,000 & $1,000,000$ & 240,000 & 700,000 & 0.000046 \\
7 & 120,000 & 750,000 & 250,000 & 760,000 & 0.000043 \\
$8 \mathrm{a}$ & 110,000 & 750,000 & 250,000 & 750,000 & 0.000049 \\
$8 \mathrm{~b}$ & 120,000 & 740,000 & 250,000 & 780,000 & 0.000042 \\
$8 \mathrm{c}$ & 76,000 & 720,000 & 200,000 & 590,000 & 0.000049 \\
9 & 150,000 & 930,000 & 260,000 & 810,000 & 0.00026 \\
10 & 130,000 & 720,000 & 250,000 & 750,000 & 0.000045 \\
\hline
\end{tabular}

Evaluation of the iron removal as a function of AFA concentration is summarized in Table 3.10 and the fraction iron removed as a function of AFA concentration is shown in Figure 3.7. A least square fit of the data at $25^{\circ} \mathrm{C}$ yields $\mathrm{y}=3 \mathrm{E}-10 \mathrm{x}+6 \mathrm{E}-05$ with $\mathrm{R}^{2}=2 \mathrm{E}-05$ and at $45^{\circ} \mathrm{C}$ yields $\mathrm{y}=2 \mathrm{E}-07 \mathrm{x}-2 \mathrm{E}-05$ with $\mathrm{R}^{2}=0.2343$. These data show no correlation between the concentration of AFA and removal of iron by oxidative leaching of the simulated tank sludge.

The concentration of iron initially present in the simulated tank waste and the amount of iron remaining after oxidative leaching is shown in Figure 3.8 for the $25^{\circ} \mathrm{C}$ tests and in Figure 3.9 for the $45^{\circ} \mathrm{C}$ tests. 


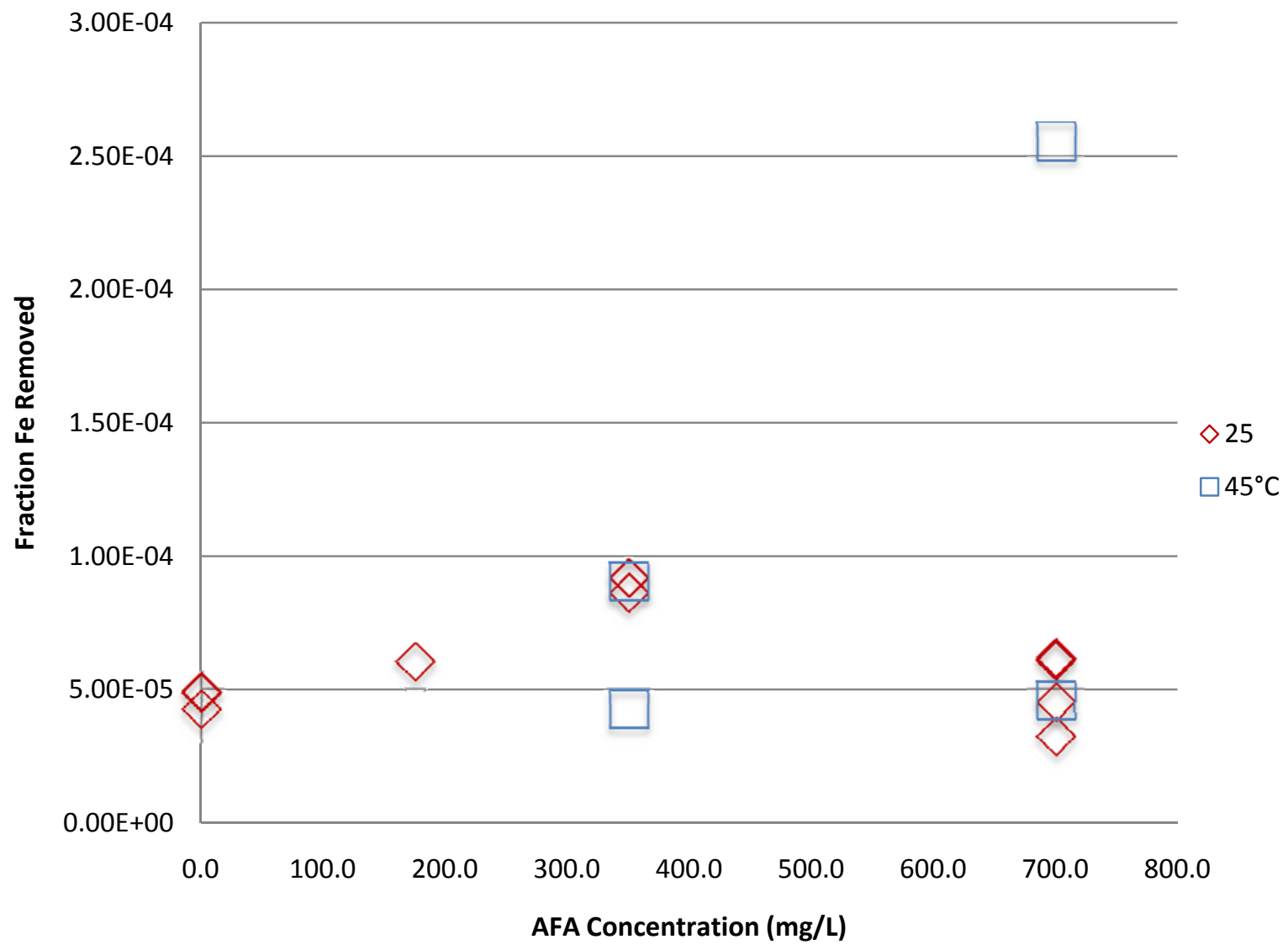

Figure 3.7. Fraction of $\mathrm{Fe}$ Removed by Oxidative Leaching at Either $25^{\circ} \mathrm{C}$ or $45^{\circ} \mathrm{C}$ 
Table 3.10. Summary of Fe Removal by Oxidative-Leach Tests

\begin{tabular}{|c|c|c|c|c|c|c|}
\hline Temperature & $\begin{array}{c}\text { AFA } \\
\text { Added, } \\
\text { mg/L }\end{array}$ & $\begin{array}{l}\text { Fraction } \\
\text { Fe } \\
\text { Removed }\end{array}$ & Data Points & Average & Stdev & RSD \\
\hline $25^{\circ} \mathrm{C}$ & 0 & $4.85 \mathrm{E}-05$ & & & & \\
\hline $25^{\circ} \mathrm{C}$ & 0 & 4.24E-05 & & & & \\
\hline $25^{\circ} \mathrm{C}$ & 0 & 4.89E-05 & $3 @ 25,0$ & 4.66E-05 & $3.67 \mathrm{E}-06$ & $7.9 \%$ \\
\hline $25^{\circ} \mathrm{C}$ & 175 & $6.03 \mathrm{E}-05$ & $1 @ 25,175$ & $6.03 \mathrm{E}-05$ & NA & NA \\
\hline $25^{\circ} \mathrm{C}$ & 350 & 8.61E-05 & & & & \\
\hline $25^{\circ} \mathrm{C}$ & 350 & $9.17 \mathrm{E}-05$ & 2@25,350 & 8.89E-05 & $3.95 \mathrm{E}-06$ & $4.4 \%$ \\
\hline $25^{\circ} \mathrm{C}$ & 700 & $6.07 \mathrm{E}-05$ & & & & \\
\hline $25^{\circ} \mathrm{C}$ & 700 & $6.16 \mathrm{E}-05$ & & & & \\
\hline $25^{\circ} \mathrm{C}$ & 700 & $3.22 \mathrm{E}-05$ & & & & \\
\hline $25^{\circ} \mathrm{C}$ & 700 & $4.51 \mathrm{E}-05$ & 4@25,700 & $5.41 \mathrm{E}-05$ & $1.91 \mathrm{E}-05$ & $35.3 \%$ \\
\hline $45^{\circ} \mathrm{C}$ & 350 & $9.05 \mathrm{E}-05$ & & & & \\
\hline $45^{\circ} \mathrm{C}$ & 350 & $4.26 \mathrm{E}-05$ & 2@45,350 & $6.65 \mathrm{E}-05$ & 3.39E-05 & $51.0 \%$ \\
\hline $45^{\circ} \mathrm{C}$ & 700 & $4.58 \mathrm{E}-05$ & & & & \\
\hline $45^{\circ} \mathrm{C}$ & 700 & $2.56 \mathrm{E}-04$ & 2@45,700 & $1.51 \mathrm{E}-04$ & 0.000148 & $98.4 \%$ \\
\hline
\end{tabular}




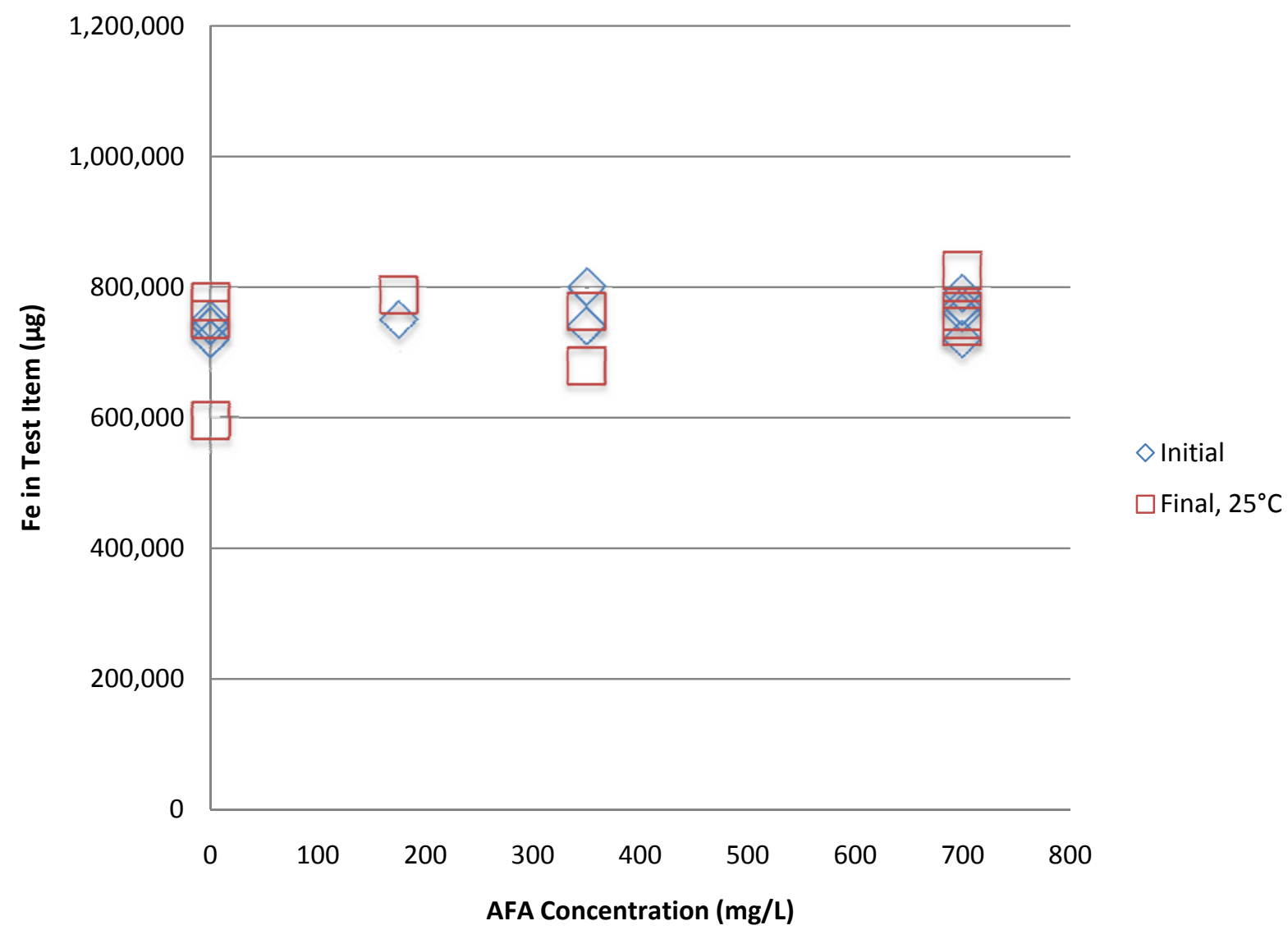

Figure 3.8. Quantity of Iron in the Solids Before Oxidative Leaching (Initial) and After Oxidative Leaching (Final) at $25^{\circ} \mathrm{C}$ 


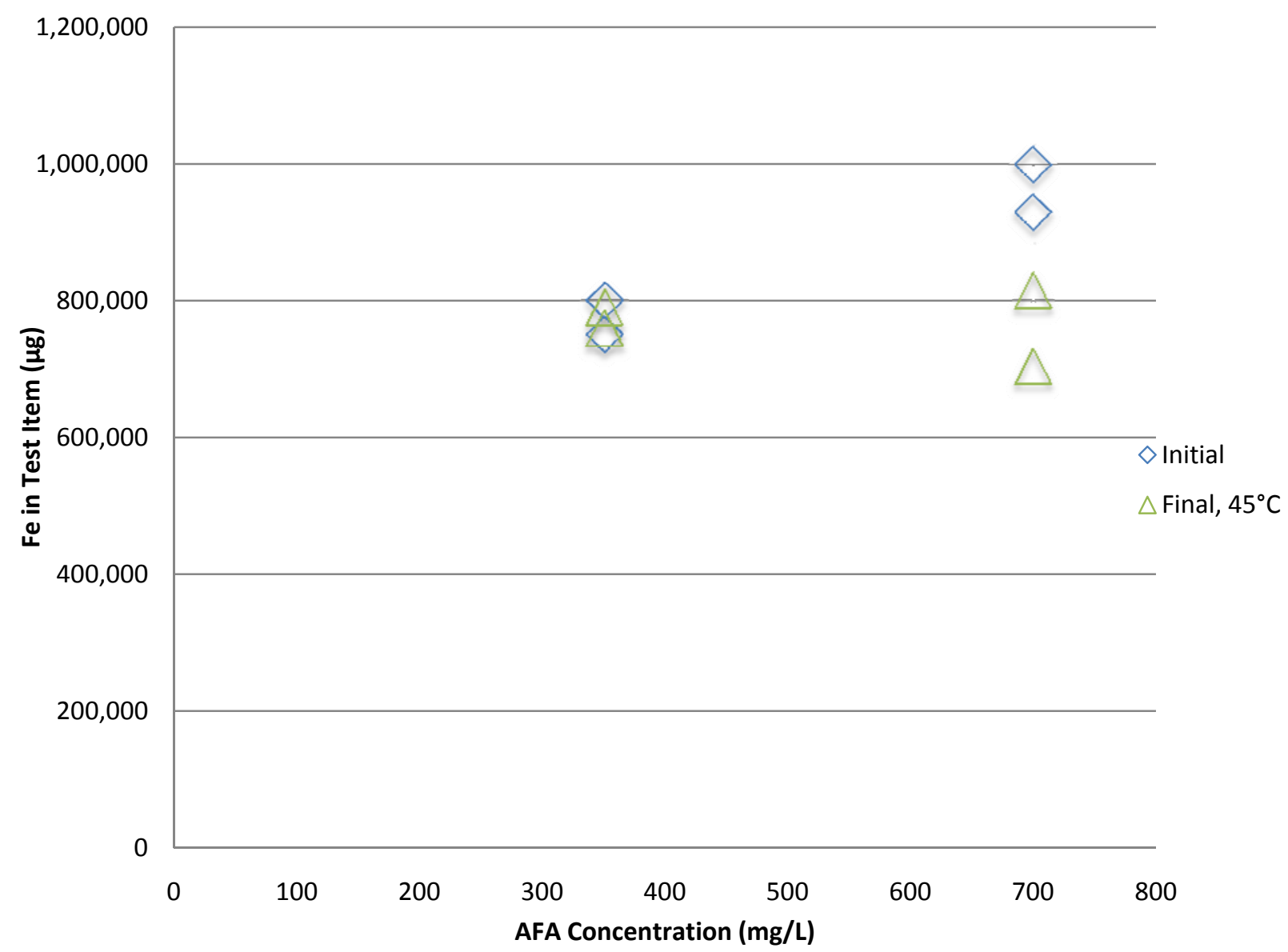

Figure 3.9. Quantity of Iron in the Solids Before Oxidative Leaching (Initial) and After Oxidative Leaching (Final) at $45^{\circ} \mathrm{C}$

\subsubsection{Manganese Results}

Manganese was not one of the oxides or hydroxides that was included in the simulant during preparation. Analysis of the initial solids reported some manganese in some of the solids. The relatively small amounts are considered either impurities or artifacts from the analytical method of the complex matrix. During the oxidative leaching process, $\mathrm{Mn}$ is added as liquid permanganate solution and is converted to an insoluble solid that precipitates as $\mathrm{MnO}_{2}$ and becomes part of the solids. All of the solutions and solids were analyzed for manganese and the results are shown in Table 3.11. Manganese was not detected in the initial $3 \mathrm{M} \mathrm{NaOH}$ or the caustic leachate. There were small amounts detected in the initial solids. There is insufficient data to determine if these trace quantities in the solids are impurities in the starting materials or artifacts of the analytical method. Comparisons of the starting solids and the solids after oxidative-leach are listed in Table 3.12. Essentially all of the added permanganate is reduced and reports to the solid phase. 
Table 3.11. Amounts of Manganese Present During Testing

\begin{tabular}{|c|c|c|c|c|c|c|}
\hline \multirow[b]{2}{*}{ Test } & \multirow[b]{2}{*}{ AFA $(m g / L)$} & \multicolumn{5}{|c|}{$\mathrm{Mn}(\mu \mathrm{g})$} \\
\hline & & $\begin{array}{c}\text { Initial } \\
\text { Leachate }\end{array}$ & $\begin{array}{c}\text { Caustic- } \\
\text { Leach } \\
\text { Supernate }+ \\
\text { Washes }\end{array}$ & $\begin{array}{c}\text { Solids After } \\
\text { Caustic- } \\
\text { Leach }\end{array}$ & $\begin{array}{l}\text { Oxidative- } \\
\text { Leach } \\
\text { Supernate }+ \\
\text { Washes }\end{array}$ & $\begin{array}{c}\text { Solids After } \\
\text { Oxidative- } \\
\text { Leach }\end{array}$ \\
\hline 1 & 175 & $<2.7$ & $<4.9$ & 1,100 & $<11$ & 560,000 \\
\hline 2 & 350 & $<2.6$ & $<5.0$ & 1,100 & $<11$ & 500,000 \\
\hline 3 & 350 & $<2.6$ & $<4.9$ & 930 & $<11$ & 570,000 \\
\hline $4 a$ & 700 & $<2.6$ & $<5.4$ & 2,000 & $<11$ & 620,000 \\
\hline $4 b$ & 700 & $<2.6$ & $<4.6$ & 1,400 & $<11$ & 560,000 \\
\hline $4 \mathrm{c}$ & 700 & $<2.6$ & $<4.9$ & 900 & $<10$ & 590,000 \\
\hline 5 & 350 & $<2.6$ & $<4.9$ & 3,500 & 1,400 & 610,000 \\
\hline 6 & 700 & $<2.6$ & $<4.9$ & 560 & $<12$ & 600,000 \\
\hline 7 & 350 & $<2.6$ & $<4.4$ & 380 & $<12$ & 600,000 \\
\hline $8 a$ & 0 & $<2.6$ & $<5.0$ & 240 & $<11$ & 590,000 \\
\hline $8 b$ & 0 & $<2.6$ & $<4.5$ & 70 & $<10$ & 600,000 \\
\hline $8 \mathrm{c}$ & 0 & $<2.6$ & $<4.7$ & $<0.11$ & 4,200 & 650,000 \\
\hline 9 & 700 & $<2.6$ & $<4.2$ & $<0.067$ & $<1.4$ & 610,000 \\
\hline 10 & 700 & $<2.6$ & $<4.7$ & $<0.061$ & 2,700 & 590,000 \\
\hline
\end{tabular}

Table 3.12. Manganese in Solids from Simulated Tank Sludge by Oxidative Leaching

\begin{tabular}{|c|c|c|c|c|c|c|}
\hline Test & & $\begin{array}{l}\text { Initial Mn } \\
(\mu \mathrm{g} / \mathrm{g})\end{array}$ & $\begin{array}{l}\text { Initial Total } \\
M n(\mu \mathrm{g})\end{array}$ & $\begin{array}{c}\text { Final Mn } \\
(\mu \mathrm{g} / \mathrm{g})\end{array}$ & $\begin{array}{l}\text { Final Total Mn } \\
\qquad(\mu \mathrm{g})\end{array}$ & $\begin{array}{c}\text { Fraction Mn } \\
\text { Removed }\end{array}$ \\
\hline & 1 & 240 & 1,100 & 180,000 & 560,000 & $\mathrm{NA}^{(\mathrm{b})}$ \\
\hline & 2 & 170 & 1,100 & 170,000 & 500,000 & NA \\
\hline & 3 & 180 & 930 & 190,000 & 570,000 & NA \\
\hline & $4 a$ & 370 & 2,000 & 210,000 & 620,000 & NA \\
\hline & $4 b$ & 300 & 1,400 & 180,000 & 560,000 & NA \\
\hline & $4 c$ & 160 & 900 & 200,000 & 590,000 & NA \\
\hline & 5 & 640 & 3,500 & 200,000 & 610,000 & NA \\
\hline & 6 & 76 & {$[560]^{(a)}$} & 200,000 & 600,000 & NA \\
\hline & 7 & 62 & {$[380]$} & 200,000 & 600,000 & NA \\
\hline & $8 \mathrm{a}$ & 36 & [240] & 200,000 & 590,000 & NA \\
\hline & $8 b$ & 11 & {$[70]$} & 200,000 & 600,000 & NA \\
\hline & $8 \mathrm{c}$ & 8 & $<72$ & 220,000 & 650,000 & NA \\
\hline & 9 & 10 & $<60$ & 200,000 & 610,000 & NA \\
\hline 10 & 10 & 7 & $<40$ & 190,000 & 590,000 & NA \\
\hline $\begin{array}{l}\text { (a) } \mathrm{V} \\
\mathrm{w} \\
\text { (b) } \mathrm{N}\end{array}$ & \multicolumn{6}{|c|}{$\begin{array}{l}\text { Values in brackets [] are } \geq \text { the method detection limit, but are }<\text { the estimated quantitation limit, } \\
\text { with errors likely to exceed } 15 \% \text {. } \\
\text { NA }=\text { Not Applicable }\end{array}$} \\
\hline
\end{tabular}


The concentration of manganese initially present in the simulated tank waste and the amount of manganese remaining after oxidative leaching is shown in Figure 3.10 for the $25^{\circ} \mathrm{C}$ tests and in Figure 3.11 for the $45^{\circ} \mathrm{C}$ tests. The manganese results separated by AFA concentration and temperature are summarized in Table 3.13 with the relative differences between multiples of the same sample types ranging between $1.2 \%$ and $9.3 \%$. The $45^{\circ} \mathrm{C}$ tests both had duplicate samples that had relative differences of $1.2 \%$ between the two. These values are essentially identical.

Table 3.13. Summary of Mn Concentration by Oxidative-Leach Tests

\begin{tabular}{|c|c|c|c|c|c|c|}
\hline Temperature & $\begin{array}{c}\text { AFA } \\
\text { Added, } \\
\text { mg/L }\end{array}$ & $\begin{array}{c}\text { Mn in } \\
\text { Final } \\
\text { Solids }(\mu \mathrm{g})\end{array}$ & Data Points & Average & Stdev & RSD \\
\hline $25^{\circ} \mathrm{C}$ & 0 & 590,000 & & & & \\
\hline $25^{\circ} \mathrm{C}$ & 0 & 600,000 & & & & \\
\hline $25^{\circ} \mathrm{C}$ & 0 & 650,000 & $3 @ 25,0$ & 610,000 & 32,000 & $5.2 \%$ \\
\hline $25^{\circ} \mathrm{C}$ & 175 & 560,000 & $1 @ 25,175$ & 560,000 & NA & NA \\
\hline $25^{\circ} \mathrm{C}$ & 350 & 500,000 & & & & \\
\hline $25^{\circ} \mathrm{C}$ & 350 & 570,000 & $2 @ 25,350$ & 540,000 & 49,000 & $9.3 \%$ \\
\hline $25^{\circ} \mathrm{C}$ & 700 & 620,000 & & & & \\
\hline $25^{\circ} \mathrm{C}$ & 700 & 560,000 & & & & \\
\hline $25^{\circ} \mathrm{C}$ & 700 & 590,000 & & & & \\
\hline $25^{\circ} \mathrm{C}$ & 700 & 590,000 & 4@25,700 & 600,000 & 19,000 & $3.2 \%$ \\
\hline $45^{\circ} \mathrm{C}$ & 350 & 610,000 & & & & \\
\hline $45^{\circ} \mathrm{C}$ & 350 & 600,000 & 2@45,350 & 600,000 & 7,100 & $1.2 \%$ \\
\hline $45^{\circ} \mathrm{C}$ & 700 & 600,000 & & & & \\
\hline $45^{\circ} \mathrm{C}$ & 700 & 610,000 & $2 @ 45,700$ & 600,000 & 7,100 & $1.2 \%$ \\
\hline \multicolumn{7}{|c|}{ NA = Not Applicable } \\
\hline
\end{tabular}




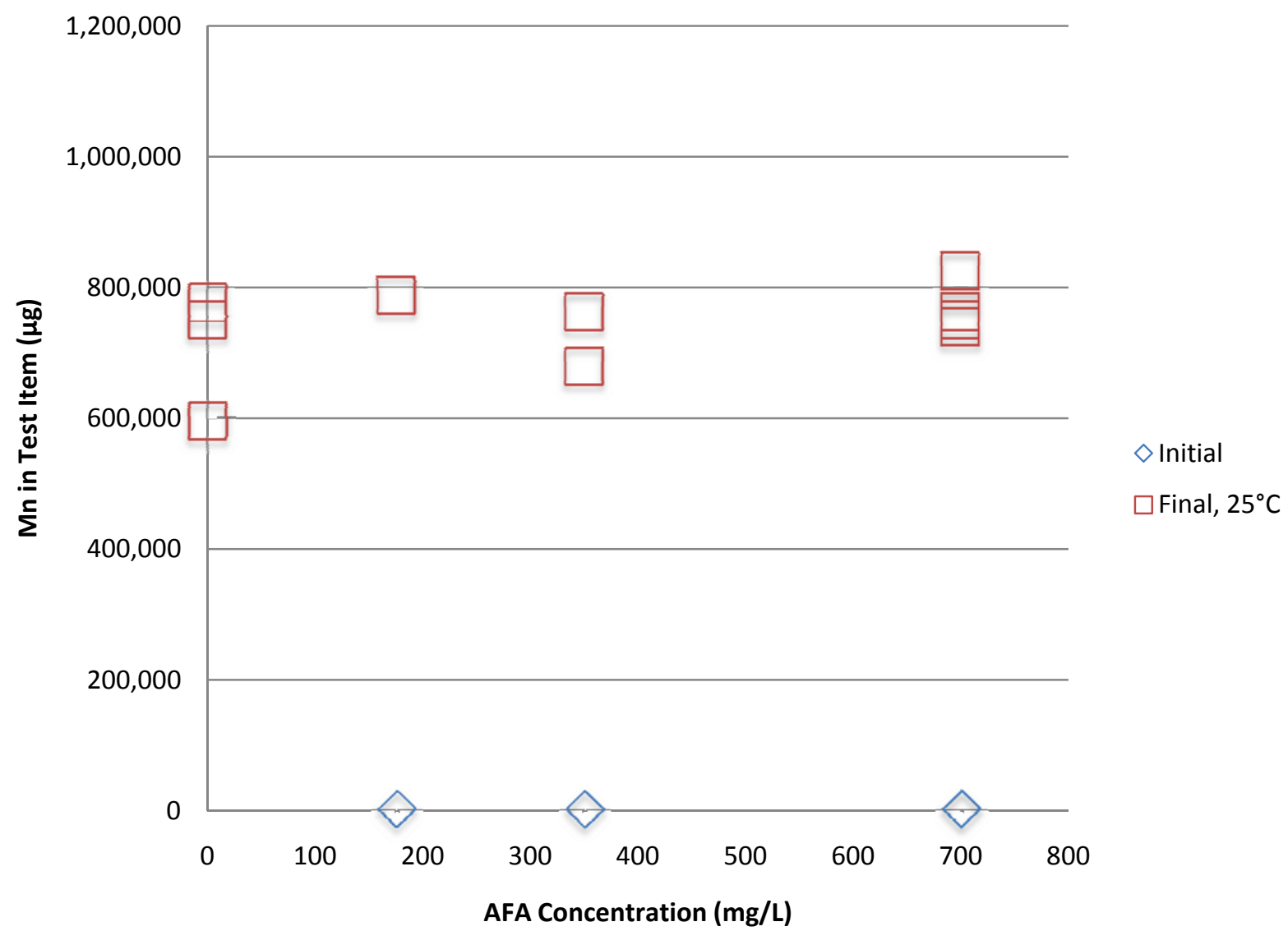

Figure 3.10. Quantity of Manganese in the Solids Before Oxidative Leaching (Initial) and After Oxidative Leaching (Final) at $25^{\circ} \mathrm{C}$ 


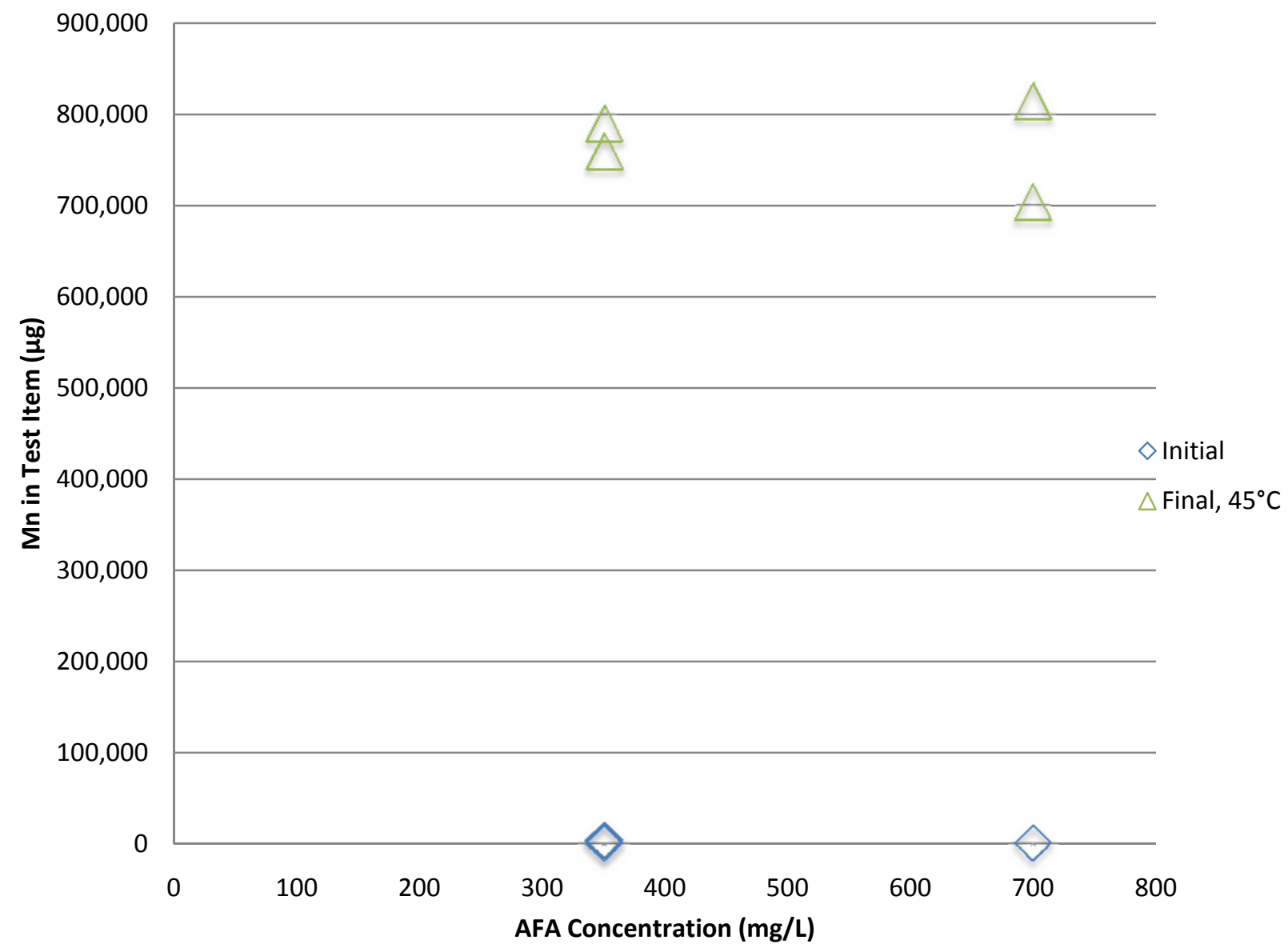

Figure 3.11. Quantity of Manganese in the Solids Before Oxidative Leaching (Initial) and After Oxidative Leaching (Final) at $45^{\circ} \mathrm{C}$ 


\subsubsection{Nickel Results}

Removal of nickel from simulated tank sludge by oxidative leaching resulted in no detectable nickel being removed. Only solutions were analyzed and all values measured for the solution nickel concentrations were below instrument detection limits. The fraction nickel removed calculation is based on the reported "less than" value from the oxidative-leach solution analysis. Results are shown in Table 3.14. Based on the amount of nickel not detected in the solution, the fraction of nickel removed is less than $0.03 \%$ of the total nickel present.

Table 3.14. Nickel Removal from Simulated Tank Sludge by Oxidative Leaching

\begin{tabular}{cccccc}
\hline Test & $\begin{array}{c}\text { Initial Ni }^{(a)} \\
(\mu \mathrm{g} / \mathrm{g})\end{array}$ & $\begin{array}{c}\text { Initial Total Ni } \\
(\mu \mathrm{g})\end{array}$ & $\begin{array}{c}\text { Final Ni }^{(\mathrm{a})} \\
(\mu \mathrm{g} / \mathrm{g})\end{array}$ & $\begin{array}{c}\text { Final Total Ni } \\
(\mu \mathrm{g})\end{array}$ & $\begin{array}{c}\text { Fraction } \\
\text { Ni } \\
\text { Removed }\end{array}$ \\
\hline 1 & 6,600 & 30,000 & 9,900 & 30,000 & $<0.00027$ \\
2 & 4,400 & 30,000 & 9,900 & 30,000 & $<0.00028$ \\
\hline 3 & 5,700 & 30,000 & 9,900 & 30,000 & $<0.00028$ \\
$4 \mathrm{a}$ & 5,500 & 30,000 & 10,000 & 30,000 & $<0.00028$ \\
$4 \mathrm{~b}$ & 6,300 & 30,000 & 9,800 & 30,000 & $<0.00029$ \\
$4 \mathrm{c}$ & 5,200 & 30,000 & 10,000 & 30,000 & $<0.00027$ \\
5 & 5,300 & 30,000 & 9,800 & 30,000 & $<0.00031$ \\
6 & 4,000 & 30,000 & 10,000 & 30,000 & $<0.00030$ \\
\hline 7 & 4,900 & 30,000 & 9,600 & 30,000 & $<0.00031$ \\
$8 \mathrm{a}$ & 4,600 & 30,000 & 9,900 & 30,000 & $<0.00027$ \\
\hline $8 \mathrm{~b}$ & 4,700 & 30,000 & 9,800 & 30,000 & $<0.00026$ \\
$8 \mathrm{c}$ & 3,100 & 30,000 & 9,800 & 30,000 & $<0.00028$ \\
\hline 9 & 4,900 & 30,000 & 9,700 & 30,000 & $<0.00030$ \\
10 & 5,300 & 30,000 & 9,700 & 30,000 & $<0.00027$
\end{tabular}

(a) Ni crucibles were used in the analytical fusions procedure to dissolve solids samples for analysis. These values are calculated based on simulant makeup and solution analyses.

Because no nickel was detected in any of the leach solutions, there was no indication of a correlation between the concentration of AFA and removal of nickel by oxidative leaching of the simulated tank sludge. The values are plotted in Figure 3.12. 


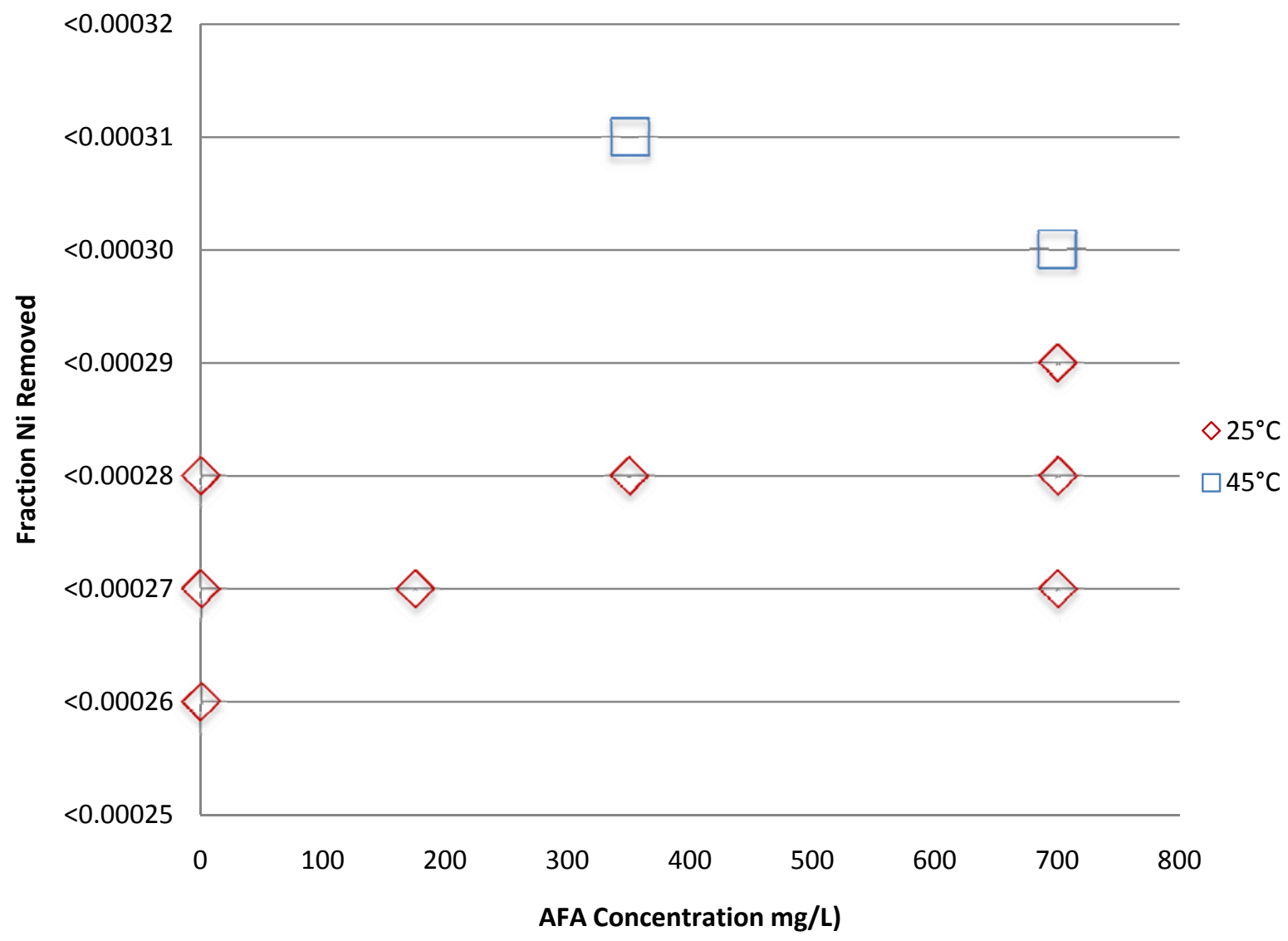

Figure 3.12. Fraction of Nickel Removed from Simulated Tank Waste by Permanganate Oxidative Leaching 


\subsubsection{Zinc Results}

Removal of zinc from simulated tank sludge by oxidative leaching resulted in $-34 \%$ to $+59 \%$ of the initial zinc being removed as seen in Table 3.15. These values are based on analysis of washed and dried solids.

Table 3.15. Zinc Removal from Simulated Tank Sludge by Oxidative Leaching

\begin{tabular}{cccccc}
\hline & & $\begin{array}{c}\text { Initial Total Zn } \\
(\mu \mathrm{g})\end{array}$ & $\begin{array}{c}\text { Final Zn } \\
(\mu \mathrm{g} / \mathrm{g})\end{array}$ & $\begin{array}{c}\text { Final Total Zn } \\
(\mu \mathrm{g})\end{array}$ & $\begin{array}{c}\text { Fraction } \\
\text { Zn } \\
\text { Removed }\end{array}$ \\
\hline 1 & 1,400 & 6,400 & 1,900 & 5,700 & 0.11 \\
2 & 1,100 & 7,200 & 1,600 & 4,800 & 0.34 \\
3 & 1,400 & 7,500 & 1,800 & 5,600 & 0.26 \\
$4 \mathrm{a}$ & 1,400 & 7,600 & 2,100 & 6,300 & 0.17 \\
$4 \mathrm{~b}$ & 1,500 & 7,200 & 1,700 & 5,200 & 0.28 \\
$4 \mathrm{c}$ & 1,200 & 6,800 & 1,900 & 5,600 & 0.17 \\
5 & 2,600 & 14,000 & 2,000 & 5,900 & 0.59 \\
6 & 1,200 & 8,800 & 2,000 & 6,000 & 0.32 \\
\hline 7 & 1,100 & 6,800 & 2,000 & 6,100 & 0.10 \\
$8 \mathrm{a}$ & 960 & 6,300 & 2,000 & 5,900 & 0.06 \\
\hline $\mathrm{b}$ & 1,200 & 7,600 & 2,000 & 6,100 & 0.20 \\
\hline $\mathrm{c}$ & 700 & 6,700 & 1,700 & 5,000 & 0.25 \\
9 & 1,200 & 7,600 & 2,200 & 6,900 & 0.10 \\
10 & 980 & 5,400 & 2,400 & 7,300 & -0.34 \\
\hline
\end{tabular}

Evaluation of the zinc removal as a function of AFA concentration is summarized in Table 3.16 and the fraction zinc removed as a function of AFA concentration is shown in Figure 3.13. A least square fit of the data at $25^{\circ} \mathrm{C}$ yields $\mathrm{y}=-0.0001 \mathrm{x}+0.2006$ with $\mathrm{R}^{2}=0.0534$ and at $45^{\circ} \mathrm{C}$ yields $\mathrm{y}=-0.0004 \mathrm{x}+0.4825$ with $\mathrm{R}^{2}=0.1143$. The fraction of $\mathrm{Zn}$ removed values of 0.59 and -0.34 lie outside the $95 \%$ confidence interval and appear to be the result of unusually high and low initial values, respectively. Removal of these two values and fitting the remaining data gives a least square fit of the data at $25^{\circ} \mathrm{C}$ of $\mathrm{y}=0.0003 \mathrm{x}-0.0088$ with $\mathrm{R}^{2}=0.2438$ and at $45^{\circ} \mathrm{C}$ yields $\mathrm{y}=7 \mathrm{E}-05 \mathrm{x}+0.179$ with $\mathrm{R}^{2}=0.0712$. These data show no correlation between the concentration of AFA and removal of zinc by oxidative leaching of the simulated tank sludge.

The concentration of zinc initially present in the simulated tank waste and the amount of zinc remaining after oxidative leaching is shown in Figure 3.14 for the $25^{\circ} \mathrm{C}$ tests and in Figure 3.15 for the $45^{\circ} \mathrm{C}$ tests. 


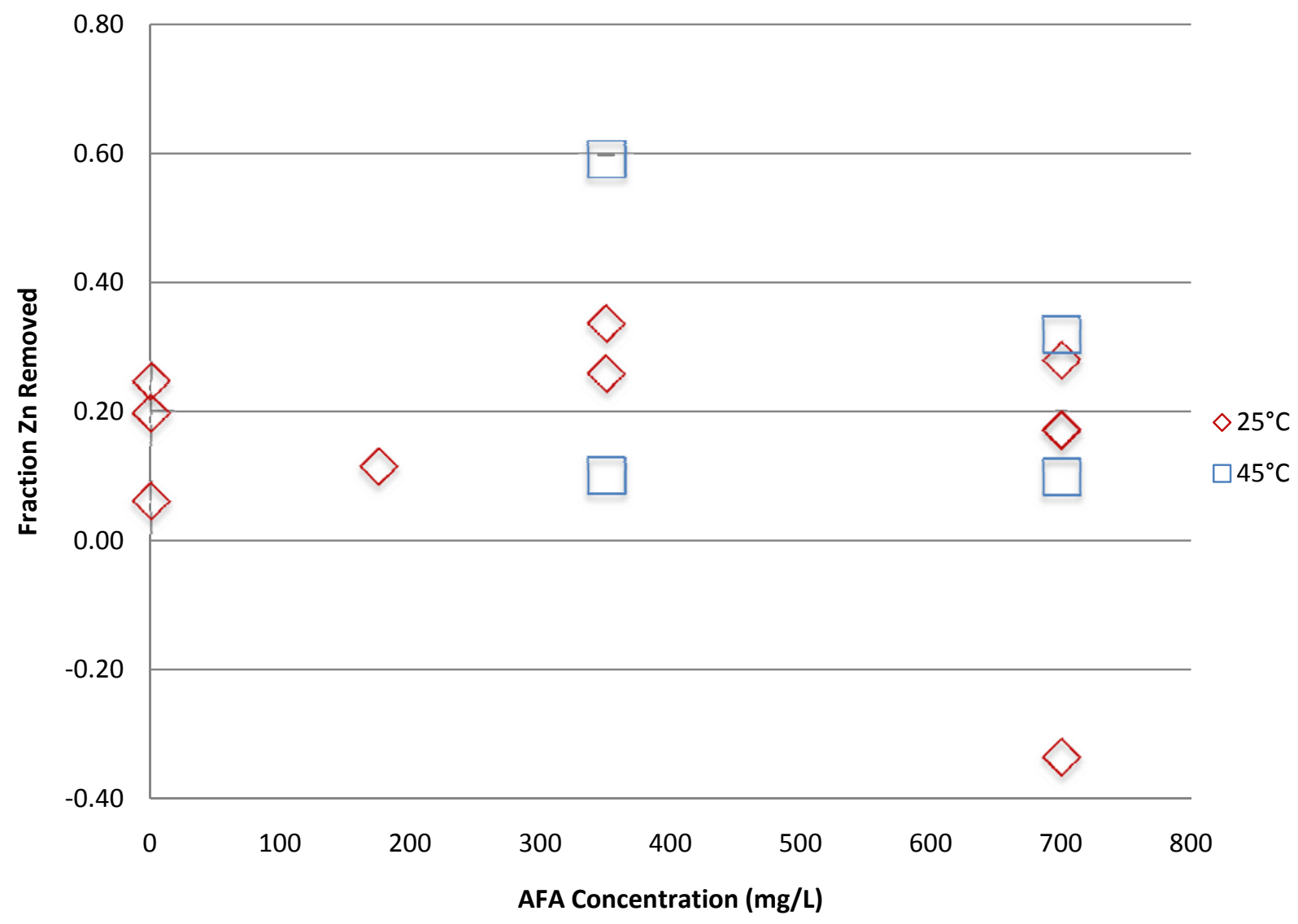

Figure 3.13. Fraction of $\mathrm{Zn}$ Removed by Oxidative Leaching at Either $25^{\circ} \mathrm{C}$ or $45^{\circ} \mathrm{C}$ 
Table 3.16. Summary of $\mathrm{Zn}$ Removal by Oxidative-Leach Tests

\begin{tabular}{|c|c|c|c|c|c|c|}
\hline Temperature & $\begin{array}{c}\text { AFA } \\
\text { Added, } \\
\mathrm{mg} / \mathrm{L}\end{array}$ & $\begin{array}{c}\text { Fraction } \\
\text { Zn } \\
\text { Removed }\end{array}$ & Data Points & Average & Stdev & RSD \\
\hline $25^{\circ} \mathrm{C}$ & 0 & 0.06 & & & & \\
\hline $25^{\circ} \mathrm{C}$ & 0 & 0.20 & & & & \\
\hline $25^{\circ} \mathrm{C}$ & 0 & 0.25 & $3 @ 25,0$ & 0.17 & 0.10 & $57 \%$ \\
\hline $25^{\circ} \mathrm{C}$ & 175 & 0.11 & $1 @ 25,175$ & 0.11 & NA & NA \\
\hline $25^{\circ} \mathrm{C}$ & 350 & 0.34 & & & & \\
\hline $25^{\circ} \mathrm{C}$ & 350 & 0.26 & $2 @ 25,350$ & 0.30 & 0.05 & $18.5 \%$ \\
\hline $25^{\circ} \mathrm{C}$ & 700 & 0.17 & & & & \\
\hline $25^{\circ} \mathrm{C}$ & 700 & 0.28 & & & & \\
\hline $25^{\circ} \mathrm{C}$ & 700 & 0.17 & & & & \\
\hline $25^{\circ} \mathrm{C}$ & 700 & -0.34 & 4@25,700 & 0.18 & 0.28 & $152 \%$ \\
\hline $45^{\circ} \mathrm{C}$ & 350 & 0.59 & & & & \\
\hline $45^{\circ} \mathrm{C}$ & 350 & 0.10 & $2 @ 45,350$ & 0.35 & 0.35 & $101 \%$ \\
\hline $45^{\circ} \mathrm{C}$ & 700 & 0.32 & & & & \\
\hline $45^{\circ} \mathrm{C}$ & 700 & 0.10 & $2 @ 45,700$ & 0.21 & 0.16 & $75 \%$ \\
\hline \multicolumn{7}{|c|}{ NA $=$ Not Applicable } \\
\hline
\end{tabular}




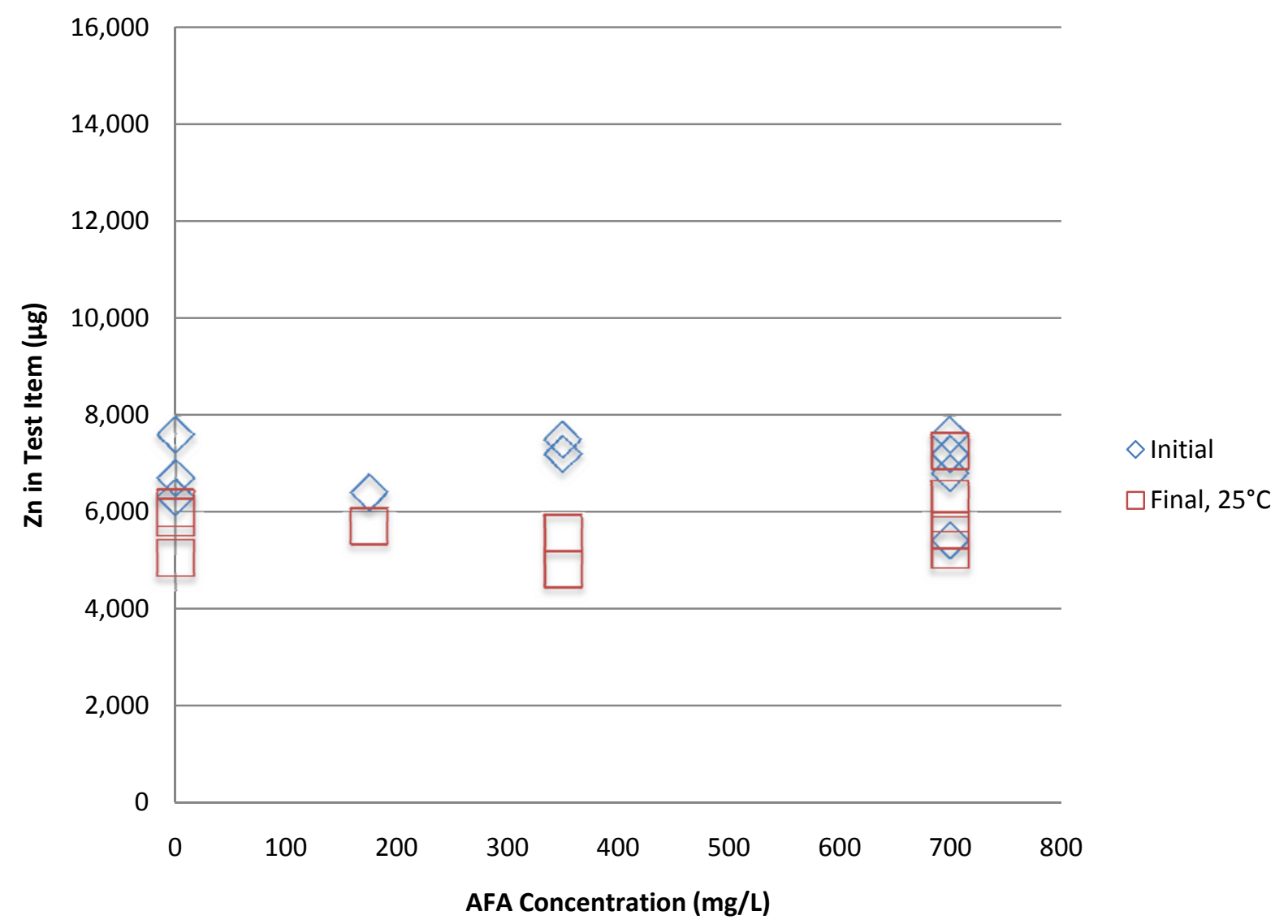

Figure 3.14. Quantity of Zinc in the Solids Before Oxidative Leaching (Initial) and After Oxidative Leaching (Final) at $25^{\circ} \mathrm{C}$ 


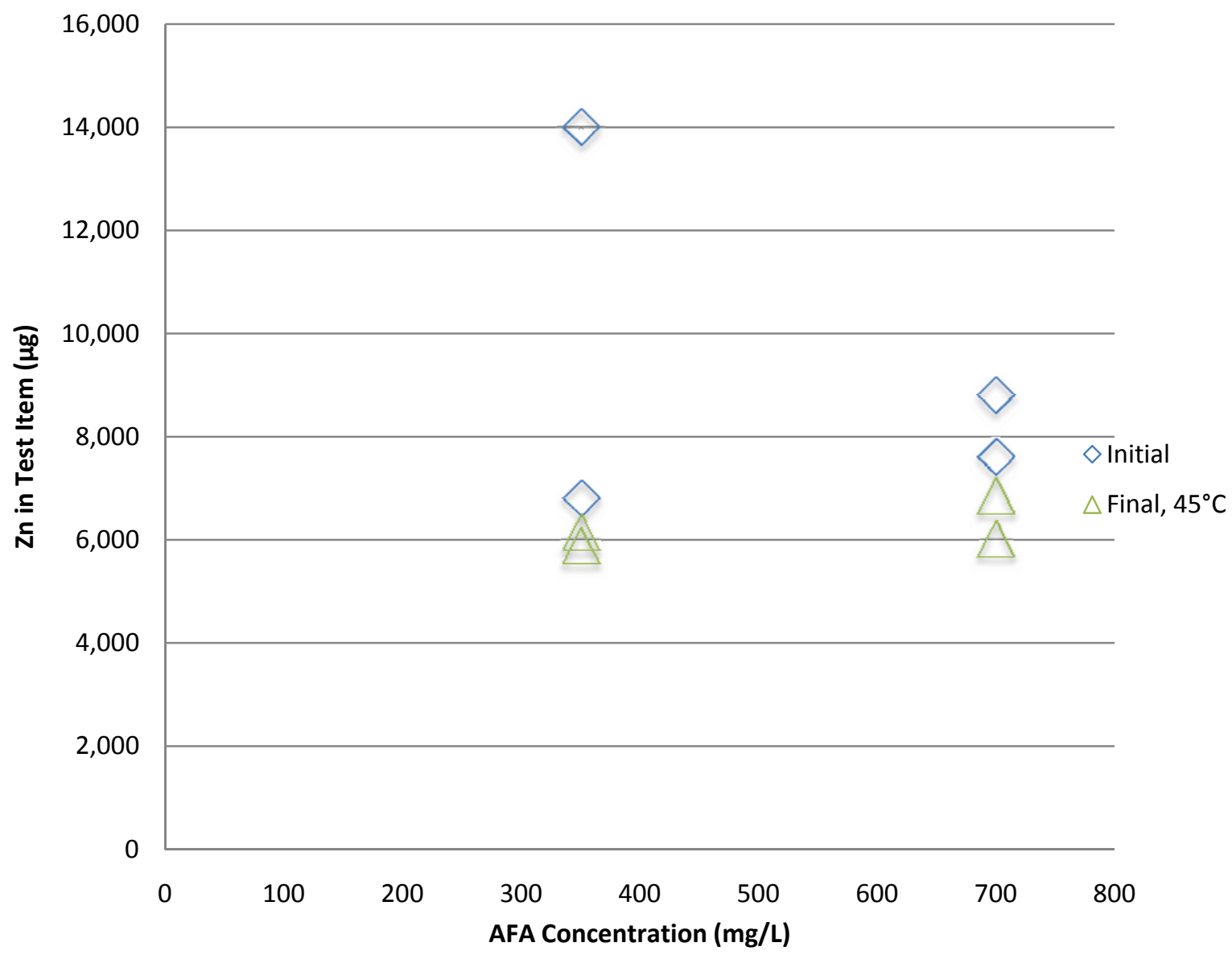

Figure 3.15. Quantity of Zinc in the Solids Before Oxidative Leaching (Initial) and After Oxidative Leaching (Final) at $45^{\circ} \mathrm{C}$ 


\subsubsection{Uranium Results}

Removal of uranium from simulated tank sludge by oxidative leaching resulted in $0.40 \%$ to $3.9 \%$ of initial uranium being removed as seen in Table 3.17. These values are based on analysis of leachate solution compared to washed and dried residual solids.

Table 3.17. Uranium Removal from Simulated Tank Sludge by Oxidative Leaching

\begin{tabular}{cccccc}
\hline & $\begin{array}{c}\text { Initial } \mathrm{U} \\
(\mu \mathrm{g} / \mathrm{g})\end{array}$ & $\begin{array}{c}\text { Initial Total U } \\
(\mu \mathrm{g})\end{array}$ & $\begin{array}{c}\text { Final U } \\
(\mu \mathrm{g} / \mathrm{g})\end{array}$ & $\begin{array}{c}\text { Final Total U } \\
(\mu \mathrm{g})\end{array}$ & $\begin{array}{c}\text { Fraction } \\
\mathrm{U} \\
\text { Removed }\end{array}$ \\
\hline 1 & {$[2,800]$} & {$[12,880]$} & 15,000 & 46,000 & 0.010 \\
2 & {$[2,000]$} & {$[13,409]$} & 15,000 & 44,000 & 0.008 \\
3 & {$[1,200]$} & {$[6,334]$} & 14,000 & 43,000 & 0.039 \\
$4 \mathrm{a}$ & {$[2,500]$} & {$[13,488]$} & 20,000 & 59,000 & 0.012 \\
$4 \mathrm{~b}$ & {$[2,900]$} & {$[13,770]$} & 14,000 & 43,000 & 0.015 \\
$4 \mathrm{c}$ & {$[1,700]$} & {$[9,920]$} & 32,000 & 97,000 & 0.014 \\
5 & {$[2,800]$} & {$[15,490]$} & 14,000 & 42,000 & 0.023 \\
6 & {$[3,500]$} & {$[26,002]$} & 33,000 & 99,000 & 0.010 \\
7 & {$[1,900]$} & {$[11,575]$} & 23,000 & 71,000 & 0.026 \\
$8 \mathrm{a}$ & {$[2,800]$} & {$[18,302]$} & 24,000 & 72,000 & 0.015 \\
$8 \mathrm{~b}$ & {$[3,400]$} & {$[21,616]$} & 23,000 & 71,000 & 0.007 \\
$8 \mathrm{c}$ & {$[1,900]$} & {$[18,227]$} & 37,000 & 110,000 & 0.004 \\
\hline 9 & {$[4,700]$} & {$[28,791]$} & 14,000 & 42,000 & 0.013 \\
10 & {$[3,000]$} & {$[16,602]$} & 28,000 & 87,000 & 0.006 \\
\hline
\end{tabular}

(a) Values in brackets [] are $\geq$ the method detection limit, but are $<$ the estimated quantitation limit, with errors likely to exceed $15 \%$.

Evaluation of the uranium removal as a function of AFA concentration is summarized in Table 3.18 and the fraction uranium removed as a function of AFA concentration is shown in Figure 3.16. A least square fit of the data at $25^{\circ} \mathrm{C}$ yields $\mathrm{y}=1 \mathrm{E}-06 \mathrm{x}+0.0168$ with $\mathrm{R}^{2}=0.001$ and at $45^{\circ} \mathrm{C}$ yields $\mathrm{y}=1 \mathrm{E}-05 \mathrm{x}+0.0016$ with $\mathrm{R}^{2}=0.3474$. These data yield lead to conflicting conclusions. At $25^{\circ} \mathrm{C}$, the data show no correlation between the concentration of AFA and removal of uranium by oxidative leaching of the simulated tank sludge, while at $45^{\circ} \mathrm{C}$, there appears to be a slight correlation, with more uranium removed at higher AFA concentration.

The concentration of uranium initially present in the simulated tank waste and the amount of uranium remaining after oxidative leaching is shown in Figure 3.17 for the $25^{\circ} \mathrm{C}$ tests and in Figure 3.18 for the $45^{\circ} \mathrm{C}$ tests. 


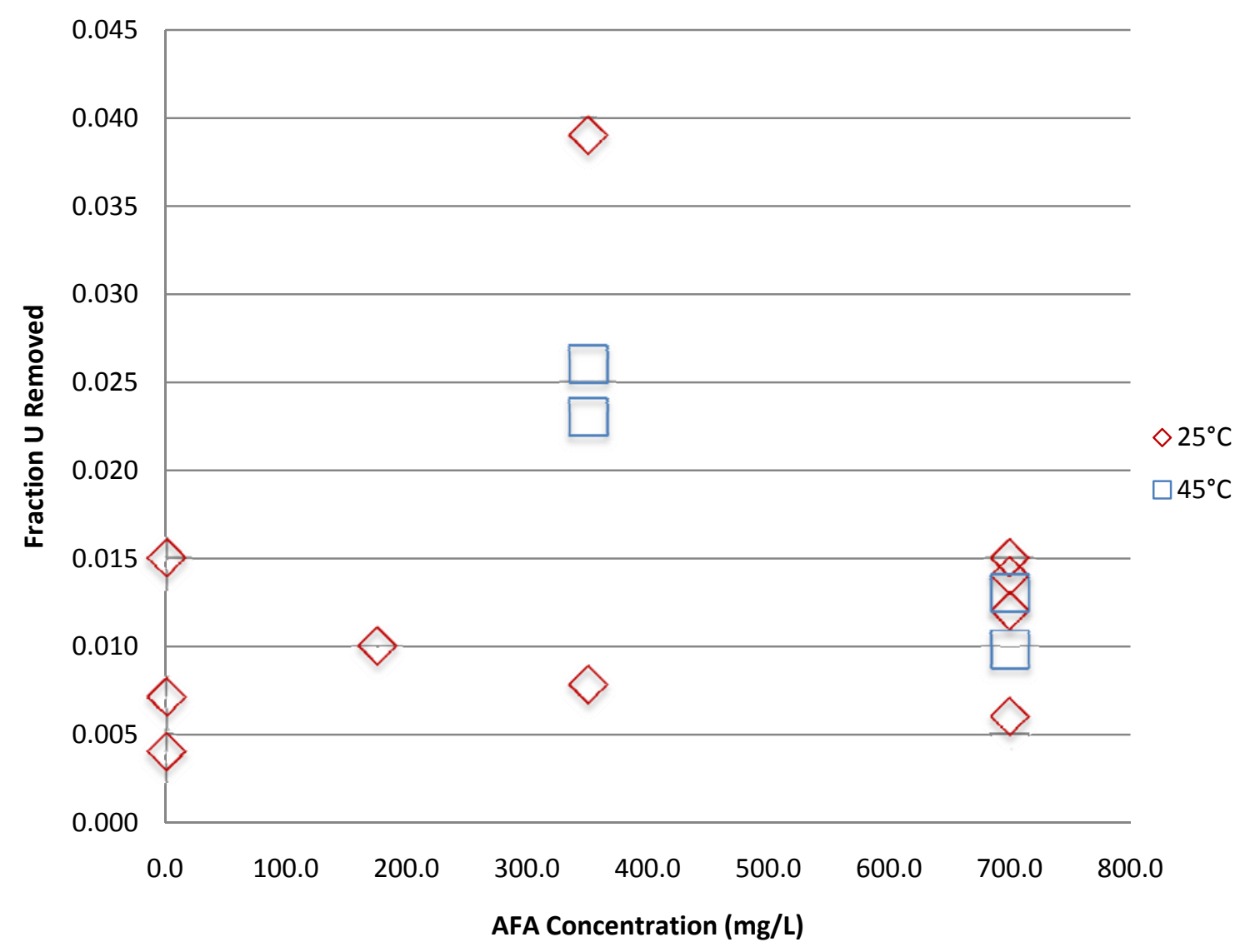

Figure 3.16. Fraction of U Removed by Oxidative Leaching at Either $25^{\circ} \mathrm{C}$ or $45^{\circ} \mathrm{C}$ 
Table 3.18. Summary of U Removal by Oxidative-Leach Tests

\begin{tabular}{|c|c|c|c|c|c|c|}
\hline Temperature & $\begin{array}{c}\text { AFA } \\
\text { Added, } \\
\text { mg/L }\end{array}$ & $\begin{array}{l}\text { Fraction U } \\
\text { Removed }\end{array}$ & Data Points & Average & Stdev & RSD \\
\hline $25^{\circ} \mathrm{C}$ & 0 & 0.015 & & & & \\
\hline $25^{\circ} \mathrm{C}$ & 0 & 0.007 & & & & \\
\hline $25^{\circ} \mathrm{C}$ & 0 & 0.0040 & $3 @ 25,0$ & 0.0087 & 0.0057 & $65 \%$ \\
\hline $25^{\circ} \mathrm{C}$ & 175 & 0.010 & $1 @ 25,175$ & 0.010 & NA & NA \\
\hline $25^{\circ} \mathrm{C}$ & 350 & 0.0078 & & & & \\
\hline $25^{\circ} \mathrm{C}$ & 350 & 0.039 & $2 @ 25,350$ & 0.023 & 0.022 & $94.3 \%$ \\
\hline $25^{\circ} \mathrm{C}$ & 700 & 0.012 & & & & \\
\hline $25^{\circ} \mathrm{C}$ & 700 & 0.015 & & & & \\
\hline $25^{\circ} \mathrm{C}$ & 700 & 0.014 & & & & \\
\hline $25^{\circ} \mathrm{C}$ & 700 & 0.0060 & 4@25,700 & 0.015 & 0.0071 & $47 \%$ \\
\hline $45^{\circ} \mathrm{C}$ & 350 & 0.023 & & & & \\
\hline $45^{\circ} \mathrm{C}$ & 350 & 0.026 & $2 @ 45,350$ & 0.025 & 0.0021 & $9 \%$ \\
\hline $45^{\circ} \mathrm{C}$ & 700 & 0.010 & & & & \\
\hline $45^{\circ} \mathrm{C}$ & 700 & 0.013 & $2 @ 45,700$ & 0.011 & 0.0023 & $20 \%$ \\
\hline \multicolumn{7}{|c|}{$\mathrm{NA}=$ Not Applicable } \\
\hline
\end{tabular}




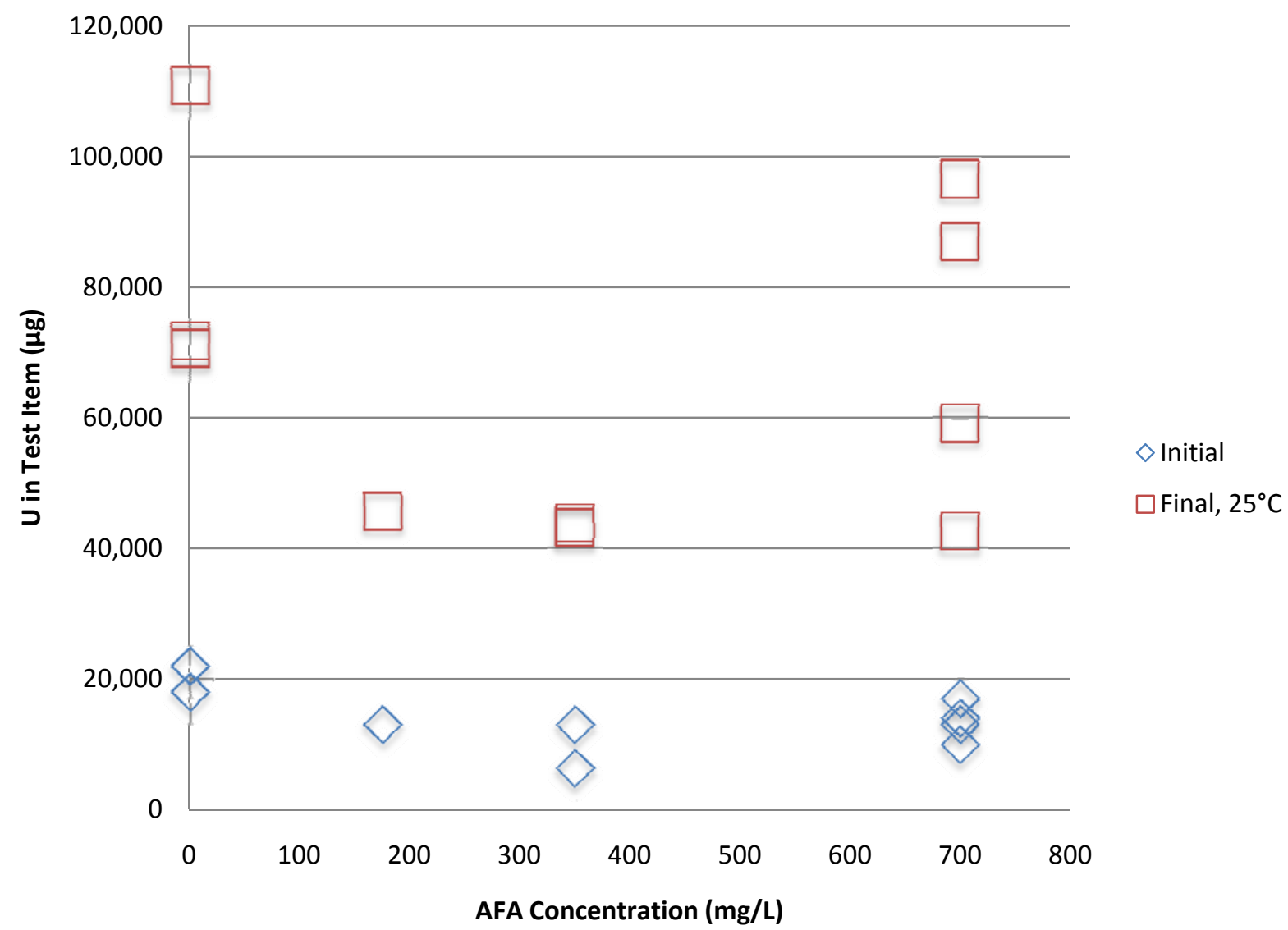

Figure 3.17. Quantity of Uranium in the Solids Before Oxidative Leaching (Initial) and After Oxidative Leaching (Final) at $25^{\circ} \mathrm{C}$ 


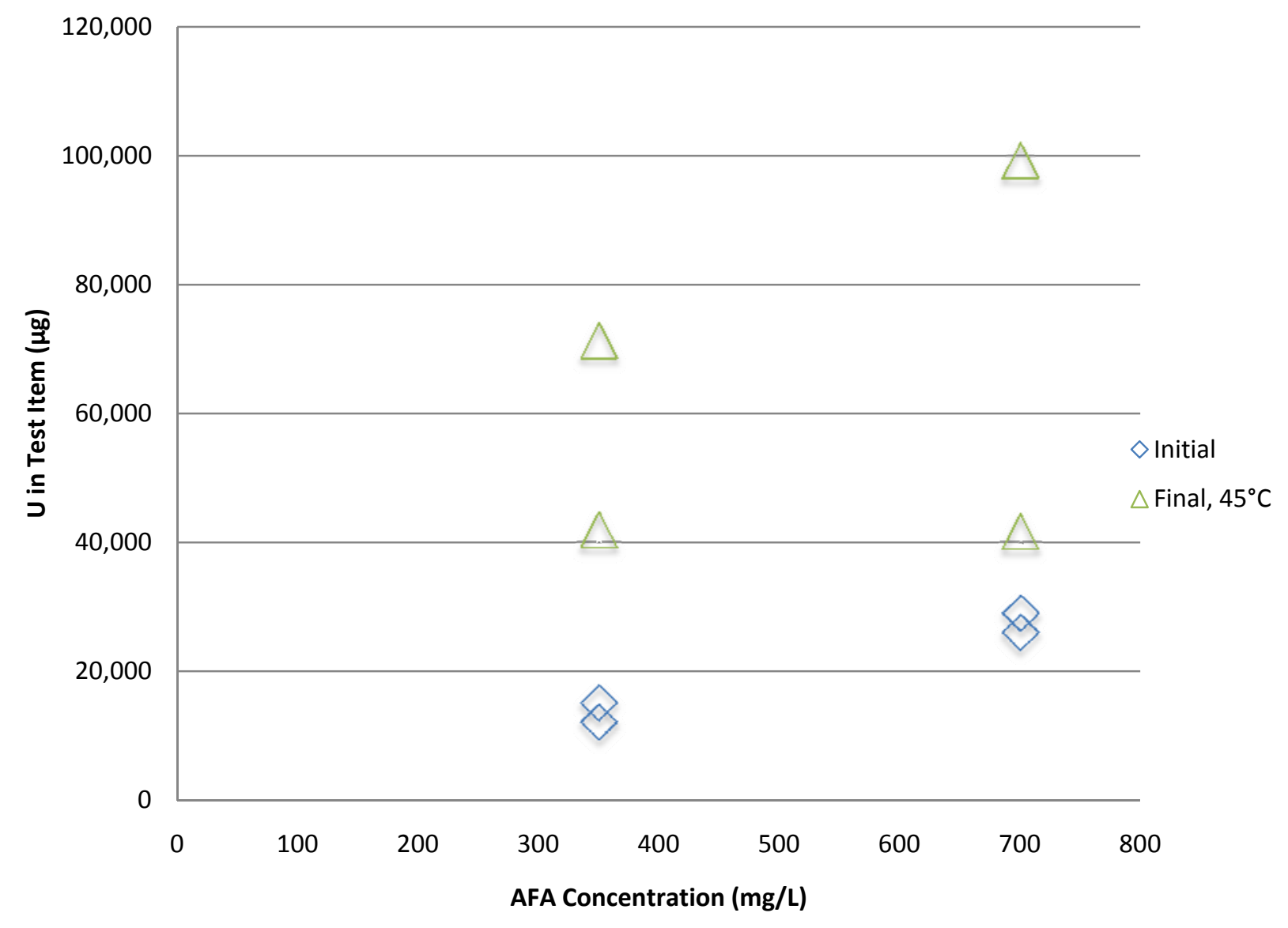

Figure 3.18. Quantity of Uranium in the Solids Before Oxidative Leaching (Initial) and After Oxidative Leaching (Final) at $45^{\circ} \mathrm{C}$

\subsection{7 $\quad{ }^{239+240} \mathrm{Pu}$ Results}

Removal of ${ }^{239+240} \mathrm{Pu}$ from simulated tank sludge by oxidative leaching resulted in $0.00040 \%$ to $0.24 \%$ of initial plutonium being removed as seen in Table 3.19 . These values are based on analysis of leachate solution compared to washed and dried residual solids. 
Table 3.19. ${ }^{239+240} \mathrm{Pu}$ Removal from Simulated Tank Sludge by Oxidative Leaching

\begin{tabular}{rrrrrr}
\hline & $\begin{array}{c}\text { Initial } \\
(\mu \mathrm{Ci} / \mathrm{g})\end{array}$ & $\begin{array}{c}\text { Initial Total } \\
{ }^{239+240} \mathrm{Pu}(\mu \mathrm{Ci})\end{array}$ & $\begin{array}{c}\text { Final }{ }^{239+240} \mathrm{Pu} \\
(\mu \mathrm{Ci} / \mathrm{g})\end{array}$ & $\begin{array}{c}\text { Final Total } \\
{ }^{239+240} \mathrm{Pu}(\mu \mathrm{Ci})\end{array}$ & $\begin{array}{c}\text { Fraction } \\
{ }^{239+240} \mathrm{Pu} \\
\text { Removed }\end{array}$ \\
\hline 1 & 14 & 63 & 20 & 60 & $2.7 \mathrm{E}-04$ \\
2 & 10 & 68 & 21 & 62 & $1.8 \mathrm{E}-04$ \\
3 & 12 & 63 & 21 & 65 & $1.2 \mathrm{E}-04$ \\
$4 \mathrm{a}$ & 14 & 77 & 21 & 63 & $1.0 \mathrm{E}-04$ \\
$4 \mathrm{~b}$ & 15 & 69 & 23 & 70 & $4.5 \mathrm{E}-05$ \\
$4 \mathrm{c}$ & 12 & 68 & 24 & 73 & $1.8 \mathrm{E}-05$ \\
5 & 13 & 70 & 25 & 75 & $2.4 \mathrm{E}-03$ \\
6 & 12 & 92 & 24 & 73 & $2.9 \mathrm{E}-05$ \\
7 & 11 & 68 & 25 & 77 & $1.5 \mathrm{E}-03$ \\
$8 \mathrm{a}$ & 11 & 73 & 23 & 70 & $8.7 \mathrm{E}-06$ \\
$8 \mathrm{~b}$ & 11 & 69 & 23 & 72 & $4.0 \mathrm{E}-06$ \\
$8 \mathrm{c}$ & 7 & 67 & 22 & 68 & $3.4 \mathrm{E}-04$ \\
9 & 13 & 79 & 24 & 74 & $4.9 \mathrm{E}-06$ \\
10 & 12 & 69 & 24 & 73 & $3.1 \mathrm{E}-04$ \\
\hline
\end{tabular}

Evaluation of the ${ }^{239+240} \mathrm{Pu}$ removal as a function of AFA concentration is summarized in Table 3.20 and the fraction ${ }^{239+240} \mathrm{Pu}$ removed as a function of AFA concentration is shown in Figure 3.19. A least square fit of the data at $25^{\circ} \mathrm{C}$ yields $\mathrm{y}=9 \mathrm{E}-07 \mathrm{x}+2 \mathrm{E}-05$ with $\mathrm{R}^{2}=0.2277$ and at $45^{\circ} \mathrm{C}$ yields $y=7 E-09 x+0.0001$ with $R^{2}=0.0001$. These data show no correlation between the concentration of AFA and removal of ${ }^{239+240} \mathrm{Pu}$ by oxidative leaching of the simulated tank sludge.

The concentration of ${ }^{239+240} \mathrm{Pu}$ initially present in the simulated tank waste solids and the amount of ${ }^{239+240} \mathrm{Pu}$ remaining after oxidative leaching is shown in Figure 3.20 for the $25^{\circ} \mathrm{C}$ tests and in Figure 3.21 for the $45^{\circ} \mathrm{C}$ tests.

There is a lot of scatter in these data that is likely due to very small particles of plutonium oxyhydroxide that are not removed by filtration. An evaluation of the solids was considered as an alternative method for quantifying the amount of ${ }^{239+240} \mathrm{Pu}$ removed by oxidative leaching. The ${ }^{239+240} \mathrm{Pu}$ in each solid test item initially ranged from 63 to $92 \mu \mathrm{Ci}$ per item with an average of $71 \mu \mathrm{Ci}$ and an RSD of $11 \%$. The final solids contained from 60 to $75 \mu \mathrm{Ci}$ per test item with an average of 70 and an RSD of $8 \%$. When the initial solids were compared to the final solids to determine the fraction of ${ }^{239+240} \mathrm{Pu}$ removed by oxidative leaching, the values ranged from -0.13 to +0.21 with an average of 0.013 and an RSD of $764 \%$. The large relative deviations appear to be due to comparing small differences between relatively large numbers. Within a group of analyses of solids, the deviations within the group are relatively small ( $8 \%$ and $11 \%)$. However, when comparing initial and final values for individual test items, the small differences produce very large relative differences and unreasonable values with approximately half of the samples having more ${ }^{239+240} \mathrm{Pu}$ in the final samples than was present in the initial test items. 


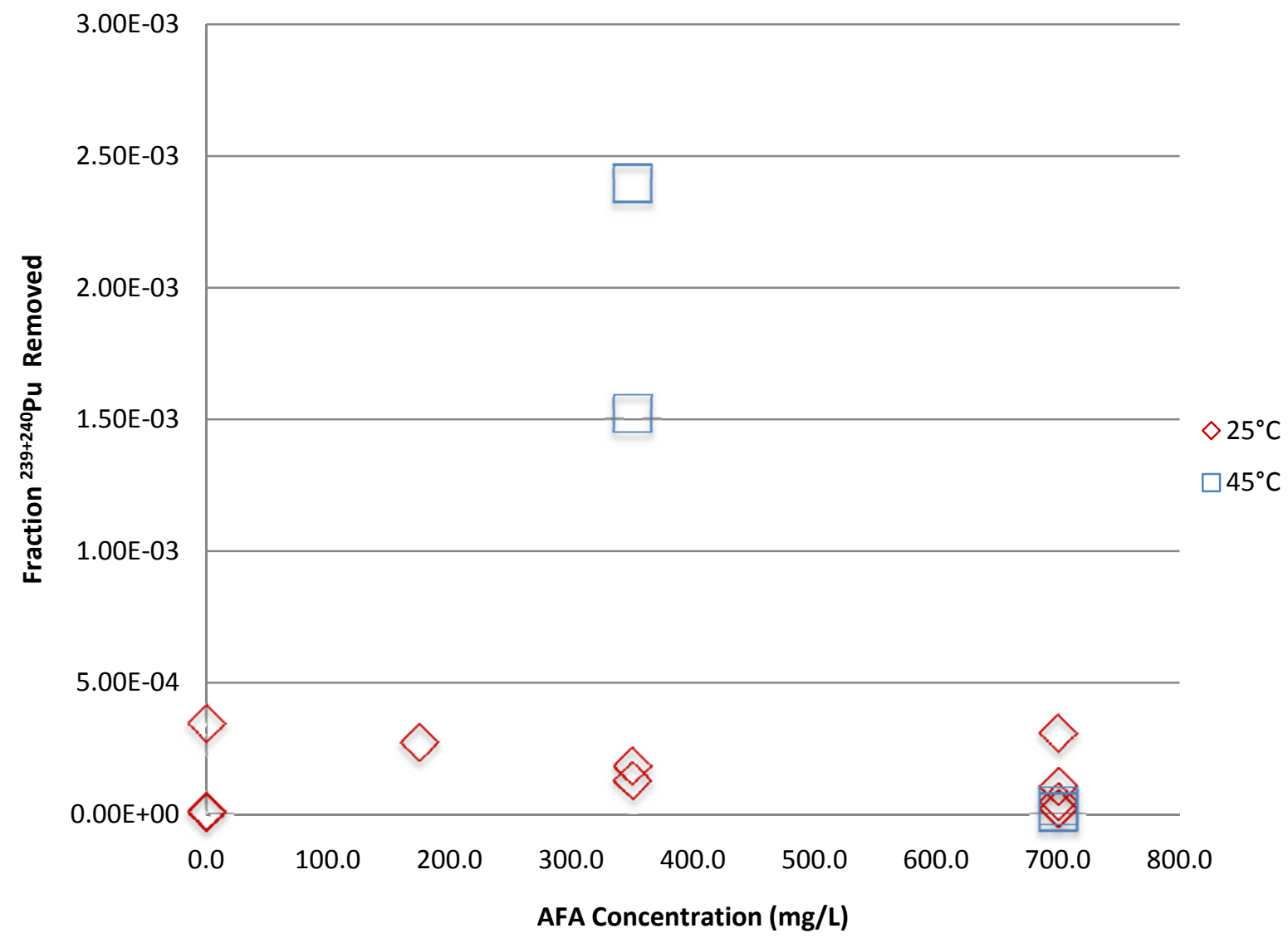

Figure 3.19. Fraction of ${ }^{239+240} \mathrm{Pu}$ Removed by Oxidative Leaching at Either $25^{\circ} \mathrm{C}$ or $45^{\circ} \mathrm{C}$ 
Table 3.20. Summary of ${ }^{239+240} \mathrm{Pu}$ Removal by Oxidative-Leach Tests

\begin{tabular}{|c|c|c|c|c|c|c|}
\hline Temperature & $\begin{array}{c}\text { AFA } \\
\text { Added, } \\
\text { mg/L }\end{array}$ & $\begin{array}{c}\text { Fraction } \\
{ }^{239+240} \mathrm{Pu} \\
\text { Removed }\end{array}$ & Data Points & Average & Stdev & RSD \\
\hline $25^{\circ} \mathrm{C}$ & 0 & $8.66 \mathrm{E}-06$ & & & & \\
\hline $25^{\circ} \mathrm{C}$ & 0 & $4.00 \mathrm{E}-06$ & & & & \\
\hline $25^{\circ} \mathrm{C}$ & 0 & $3.41 \mathrm{E}-04$ & $3 @ 25,0$ & $1.2 \mathrm{E}-04$ & $1.9 \mathrm{E}-04$ & $164 \%$ \\
\hline $25^{\circ} \mathrm{C}$ & 175 & $2.70 \mathrm{E}-04$ & $1 @ 25,175$ & 2.7E-04 & NA & NA \\
\hline $25^{\circ} \mathrm{C}$ & 350 & $1.80 \mathrm{E}-04$ & & & & \\
\hline $25^{\circ} \mathrm{C}$ & 350 & $1.25 \mathrm{E}-04$ & $2 @ 25,350$ & $1.5 \mathrm{E}-04$ & $3.9 \mathrm{E}-05$ & $25.6 \%$ \\
\hline $25^{\circ} \mathrm{C}$ & 700 & $1.02 \mathrm{E}-04$ & & & & \\
\hline $25^{\circ} \mathrm{C}$ & 700 & $4.52 \mathrm{E}-05$ & & & & \\
\hline $25^{\circ} \mathrm{C}$ & 700 & $1.76 \mathrm{E}-05$ & & & & \\
\hline $25^{\circ} \mathrm{C}$ & 700 & $3.05 \mathrm{E}-04$ & 4@25, 700 & $6.3 \mathrm{E}-04$ & $9.5 \mathrm{E}-04$ & $150 \%$ \\
\hline $45^{\circ} \mathrm{C}$ & 350 & $2.40 \mathrm{E}-03$ & & & & \\
\hline $45^{\circ} \mathrm{C}$ & 350 & $1.52 \mathrm{E}-03$ & $2 @ 45,350$ & $2.0 \mathrm{E}-03$ & $6.2 \mathrm{E}-04$ & $32 \%$ \\
\hline $45^{\circ} \mathrm{C}$ & 700 & $2.89 \mathrm{E}-05$ & & & & \\
\hline $45^{\circ} \mathrm{C}$ & 700 & 4.89E-06 & $2 @ 45,700$ & $1.7 \mathrm{E}-05$ & $1.7 \mathrm{E}-05$ & $100 \%$ \\
\hline \multicolumn{7}{|c|}{$\mathrm{NA}=$ Not Applicable } \\
\hline
\end{tabular}




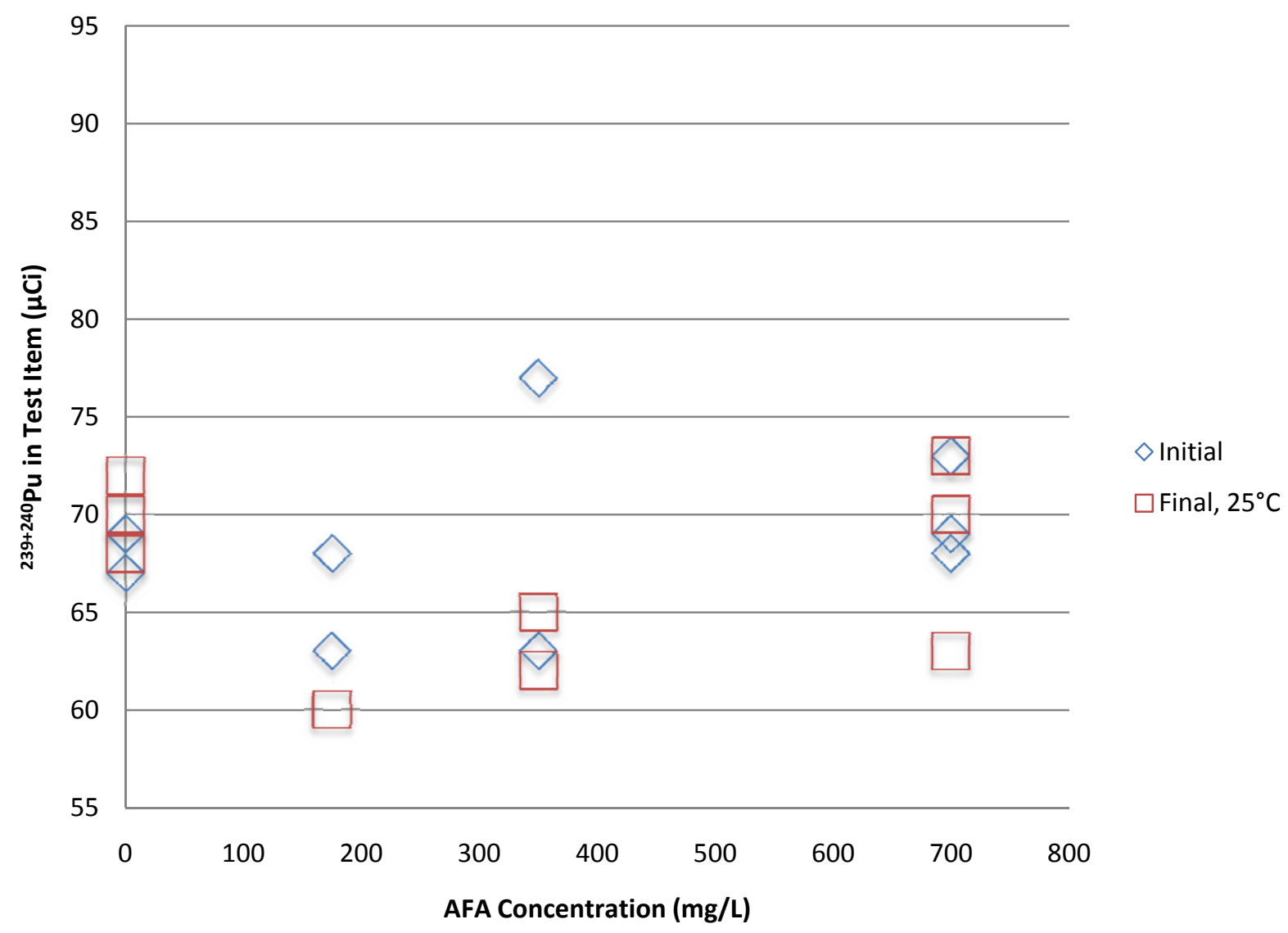

Figure 3.20. Quantity of ${ }^{239+240} \mathrm{Pu}$ in the Solids Before Oxidative Leaching (Initial) and After Oxidative Leaching (Final) at $25^{\circ} \mathrm{C}$ 


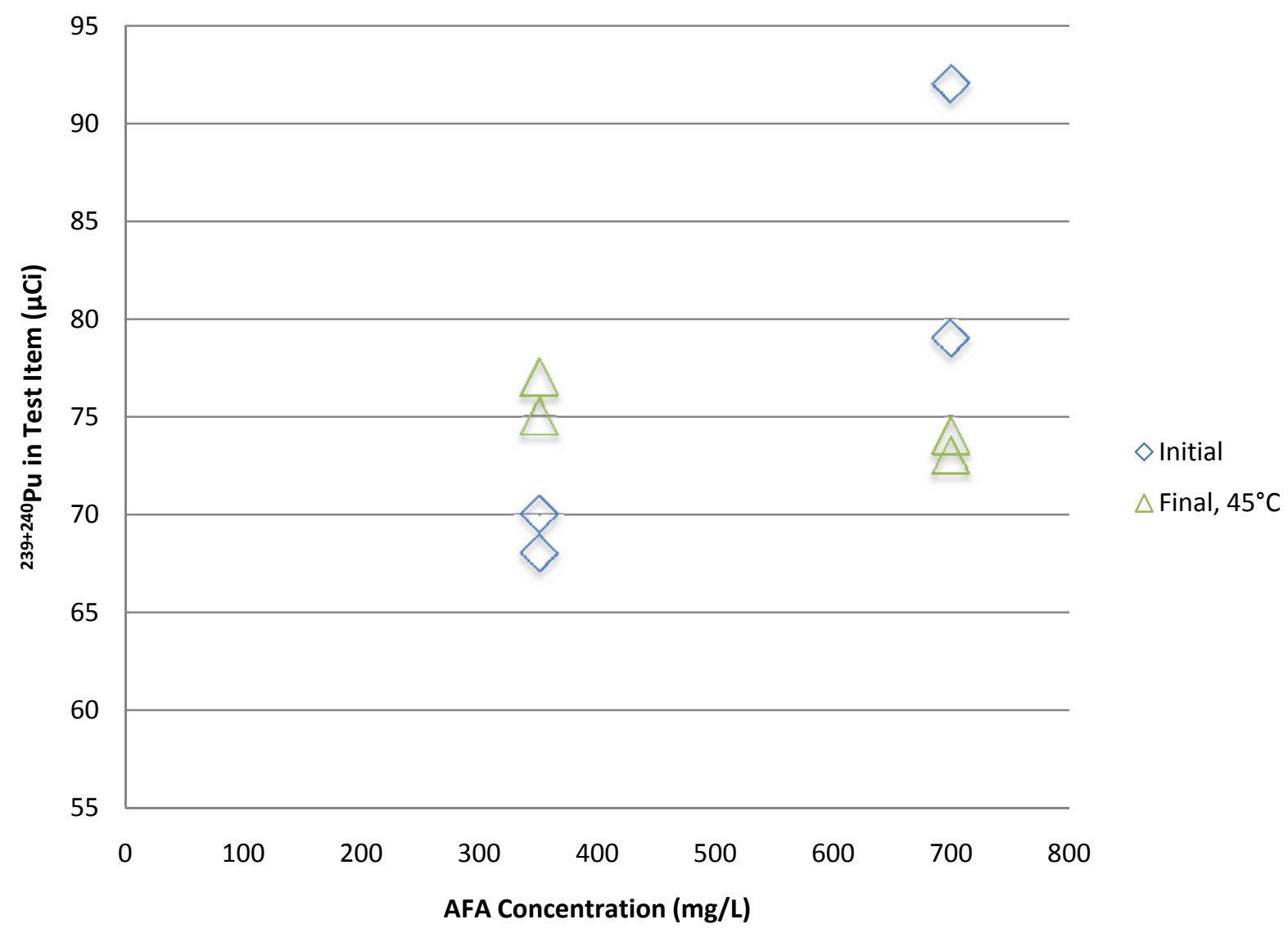

Figure 3.21. Quantity of ${ }^{239+240} \mathrm{Pu}$ in the Solids Before Oxidative Leaching (Initial) and After Oxidative Leaching (Final) at $45^{\circ} \mathrm{C}$ 


\subsection{8 $\quad{ }^{238} \mathrm{Pu}+{ }^{241} \mathrm{Am}$ Results}

Removal of ${ }^{238} \mathrm{Pu}^{241} \mathrm{Am}$ from simulated tank sludge by oxidative leaching resulted in $0.0032 \%$ to $0.026 \%$ of initial plutonium being removed as seen in Table 3.21. These values are based on analysis of leachate solution compared to washed and dried residual solids.

Table 3.21. ${ }^{238} \mathrm{Pu}+{ }^{241} \mathrm{Am}$ Removal from Simulated Tank Sludge by Oxidative Leaching

\begin{tabular}{rccccc}
\hline Test & $\begin{array}{c}\text { Initial } \\
{ }^{238}{ }^{241} \mathrm{Am} \\
(\mu \mathrm{Ci} / \mathrm{g})\end{array}$ & $\begin{array}{c}\text { Initial Total } \\
{ }^{238} \mathrm{Pu}^{241} \mathrm{Am} \\
(\mu \mathrm{g})\end{array}$ & $\begin{array}{c}\text { Final } \\
{ }^{238} \mathrm{Pu}^{241} \mathrm{Am} \\
(\mu \mathrm{g} / \mathrm{g})\end{array}$ & $\begin{array}{c}\text { Final Total } \\
{ }^{238} \mathrm{Pu}^{241} \mathrm{Am} \\
(\mu \mathrm{g})\end{array}$ & $\begin{array}{c}\text { Fraction } \\
{ }^{238} \mathrm{Pu}+{ }^{241} \mathrm{Am} \\
\text { Removed }\end{array}$ \\
\hline 1 & 0.28 & 1.3 & 0.59 & 1.8 & $1.96 \mathrm{E}-04$ \\
2 & 0.29 & 1.9 & 0.55 & 1.6 & $1.37 \mathrm{E}-04$ \\
3 & 0.25 & 1.3 & 0.58 & 1.8 & $9.46 \mathrm{E}-05$ \\
$4 \mathrm{a}$ & 0.36 & 1.9 & 0.59 & 1.8 & $<8 . \mathrm{E}-05$ \\
$4 \mathrm{~b}$ & 0.36 & 1.7 & 0.61 & 1.9 & $<9 . \mathrm{E}-05$ \\
$4 \mathrm{c}$ & 0.31 & 1.8 & 0.64 & 1.9 & $<3 . \mathrm{E}-05$ \\
5 & 0.31 & 1.7 & 0.64 & 1.9 & $1.80 \mathrm{E}-03$ \\
6 & 0.33 & 2.5 & 0.56 & 1.7 & $<3 . \mathrm{E}-05$ \\
7 & 0.27 & 1.7 & 0.63 & 1.9 & $1.08 \mathrm{E}-03$ \\
$8 \mathrm{a}$ & 0.36 & 2.3 & 0.58 & 1.7 & $<3 . \mathrm{E}-05$ \\
$8 \mathrm{~b}$ & 0.27 & 1.7 & 0.58 & 1.8 & $<3 . \mathrm{E}-05$ \\
$8 \mathrm{c}$ & 0.19 & 1.8 & 0.60 & 1.8 & $2.25 \mathrm{E}-04$ \\
9 & 0.31 & 1.9 & 0.63 & 1.9 & $<1 . \mathrm{E}-05$ \\
10 & 0.35 & 2.0 & 0.58 & 1.8 & $2.43 \mathrm{E}-04$ \\
\hline
\end{tabular}

Evaluation of the ${ }^{238} \mathrm{Pu}+{ }^{241} \mathrm{Am}$ removal as a function of AFA concentration is summarized in Table 3.22 and the fraction ${ }^{238} \mathrm{Pu}^{241} \mathrm{Am}$ removed as a function of AFA concentration is shown in Figure 3.22. A least square fit of the data at $25^{\circ} \mathrm{C}$ yields $\mathrm{y}=9 \mathrm{E}-07 \mathrm{x}+2 \mathrm{E}-05$ with $\mathrm{R}^{2}=0.2277$ and at $45^{\circ} \mathrm{C}$ yields $\mathrm{y}=7 \mathrm{E}-09 \mathrm{x}+0.0001$ with $\mathrm{R}^{2}=0.0001$. These data show no correlation between the concentration of AFA and removal of ${ }^{238} \mathrm{Pu}+{ }^{241} \mathrm{Am}$ by oxidative leaching of the simulated tank sludge.

The concentration of ${ }^{238} \mathrm{Pu}+{ }^{241} \mathrm{Am}$ initially present in the simulated tank waste solids and the amount of ${ }^{238} \mathrm{Pu}+{ }^{241} \mathrm{Am}$ remaining after oxidative leaching is shown in Figure 3.23 for the $25^{\circ} \mathrm{C}$ tests and in Figure 3.24 for the $45^{\circ} \mathrm{C}$ tests. 


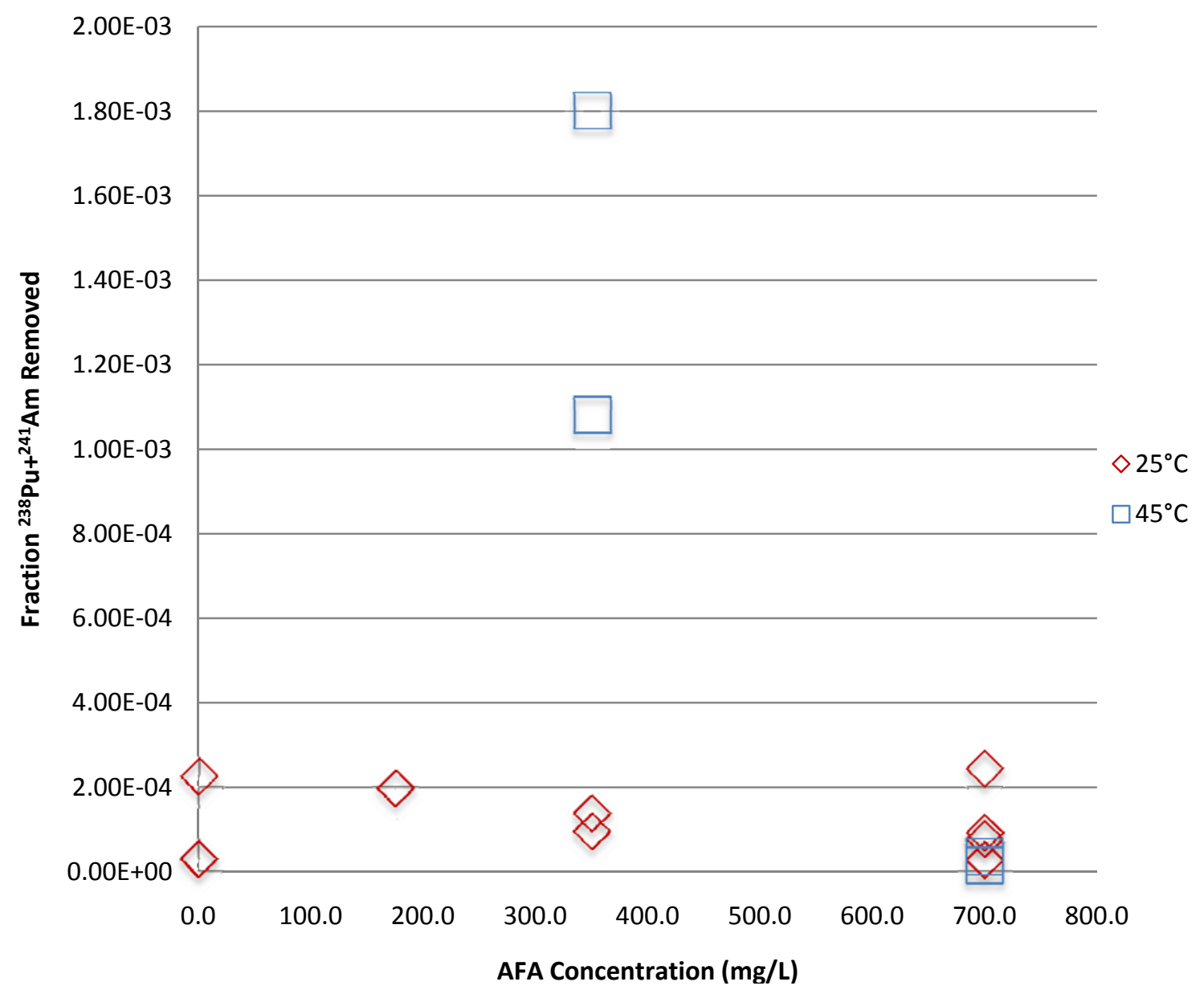

Figure 3.22. Fraction of ${ }^{238} \mathrm{Pu}+{ }^{241} \mathrm{Am}$ Removed by Oxidative Leaching at Either $25^{\circ} \mathrm{C}$ or $45^{\circ} \mathrm{C}$ 
Table 3.22. Summary of ${ }^{238} \mathrm{Pu}+{ }^{241} \mathrm{Am}$ Removal by Oxidative-Leach Tests

\begin{tabular}{|c|c|c|c|c|c|c|}
\hline Temperature & $\begin{array}{c}\text { AFA } \\
\text { Added, } \\
\text { mg/L }\end{array}$ & $\begin{array}{c}\text { Fraction } \\
{ }^{238} \mathrm{Pu}^{241} \mathrm{Am} \\
\text { Removed }\end{array}$ & Data Points & Average & Stdev & RSD \\
\hline $25^{\circ} \mathrm{C}$ & 0 & $<3.0$. E-05 & & & & \\
\hline $25^{\circ} \mathrm{C}$ & 0 & $<2.8 . \mathrm{E}-05$ & & & & \\
\hline $25^{\circ} \mathrm{C}$ & 0 & $2.25 \mathrm{E}-04$ & $3 @ 25,0$ & $9.4 \mathrm{E}-05$ & $1.1 \mathrm{E}-04$ & $120 \%$ \\
\hline $25^{\circ} \mathrm{C}$ & 175 & $1.96 \mathrm{E}-04$ & $1 @ 25,175$ & $2.0 \mathrm{E}-04$ & NA & NA \\
\hline $25^{\circ} \mathrm{C}$ & 350 & $1.37 \mathrm{E}-04$ & & & & \\
\hline $25^{\circ} \mathrm{C}$ & 350 & $9.46 \mathrm{E}-05$ & 2@25,350 & $1.2 \mathrm{E}-04$ & $3.0 \mathrm{E}-05$ & $26.0 \%$ \\
\hline $25^{\circ} \mathrm{C}$ & 700 & $<7.6$. E-05 & & & & \\
\hline $25^{\circ} \mathrm{C}$ & 700 & $<9.1$.E-05 & & & & \\
\hline $25^{\circ} \mathrm{C}$ & 700 & $<2.7$.E-05 & & & & \\
\hline $25^{\circ} \mathrm{C}$ & 700 & $2.43 \mathrm{E}-04$ & 4@25,700 & $4.8 \mathrm{E}-04$ & $6.9 \mathrm{E}-04$ & $145 \%$ \\
\hline $45^{\circ} \mathrm{C}$ & 350 & $1.80 \mathrm{E}-03$ & & & & \\
\hline $45^{\circ} \mathrm{C}$ & 350 & $1.08 \mathrm{E}-03$ & 2@45,350 & $1.4 \mathrm{E}-03$ & $5.1 \mathrm{E}-04$ & $35 \%$ \\
\hline $45^{\circ} \mathrm{C}$ & 700 & $<3.5$.E-05 & & & & \\
\hline $45^{\circ} \mathrm{C}$ & 700 & $<1.5$.E-05 & 2@45,700 & $2.5 \mathrm{E}-05$ & $1.4 \mathrm{E}-05$ & $57 \%$ \\
\hline
\end{tabular}




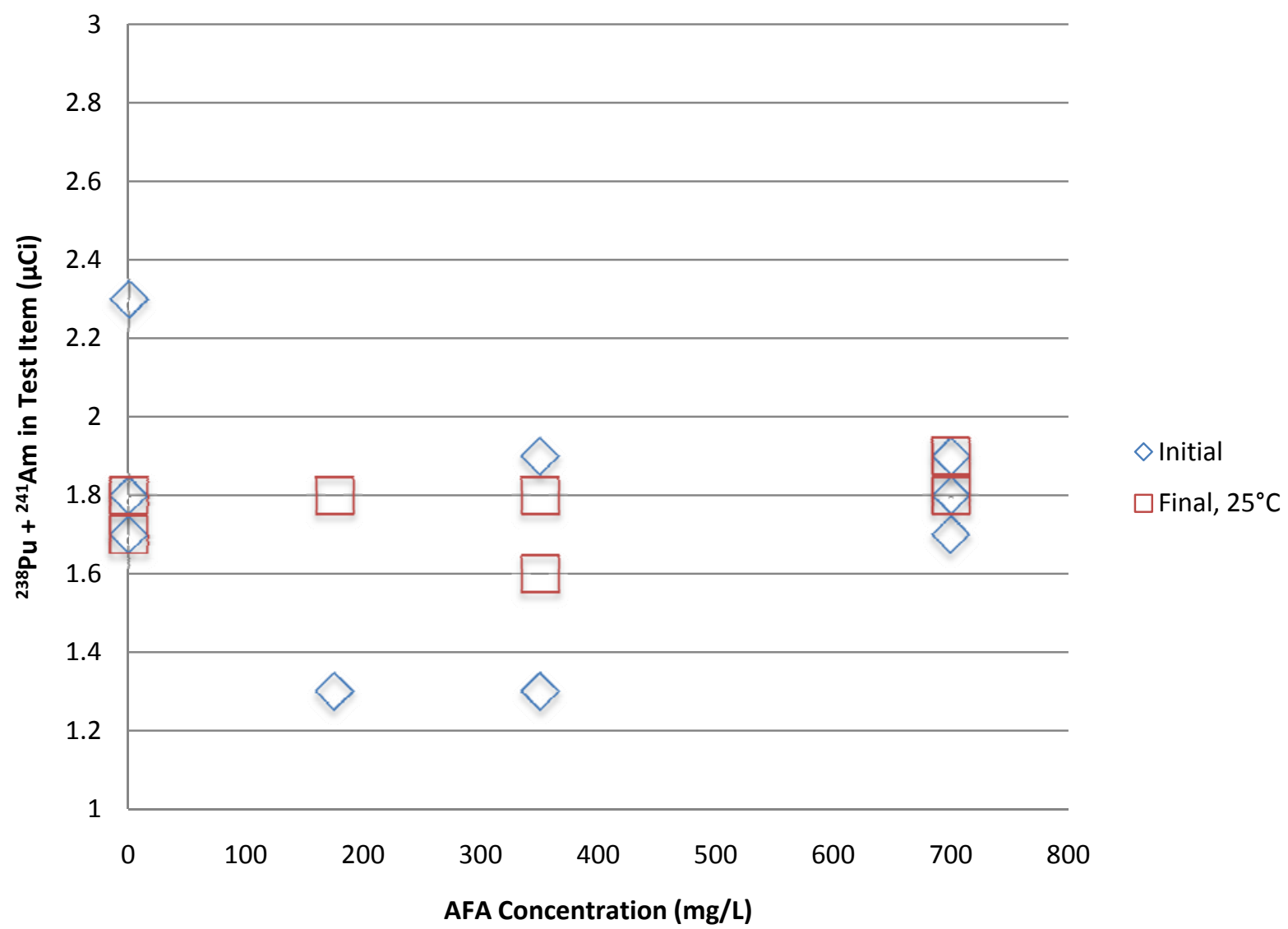

Figure 3.23. Quantity of ${ }^{238} \mathrm{Pu}+{ }^{241} \mathrm{Am}$ in the Solids Before Oxidative Leaching (Initial) and After Oxidative Leaching (Final) at $25^{\circ} \mathrm{C}$ 


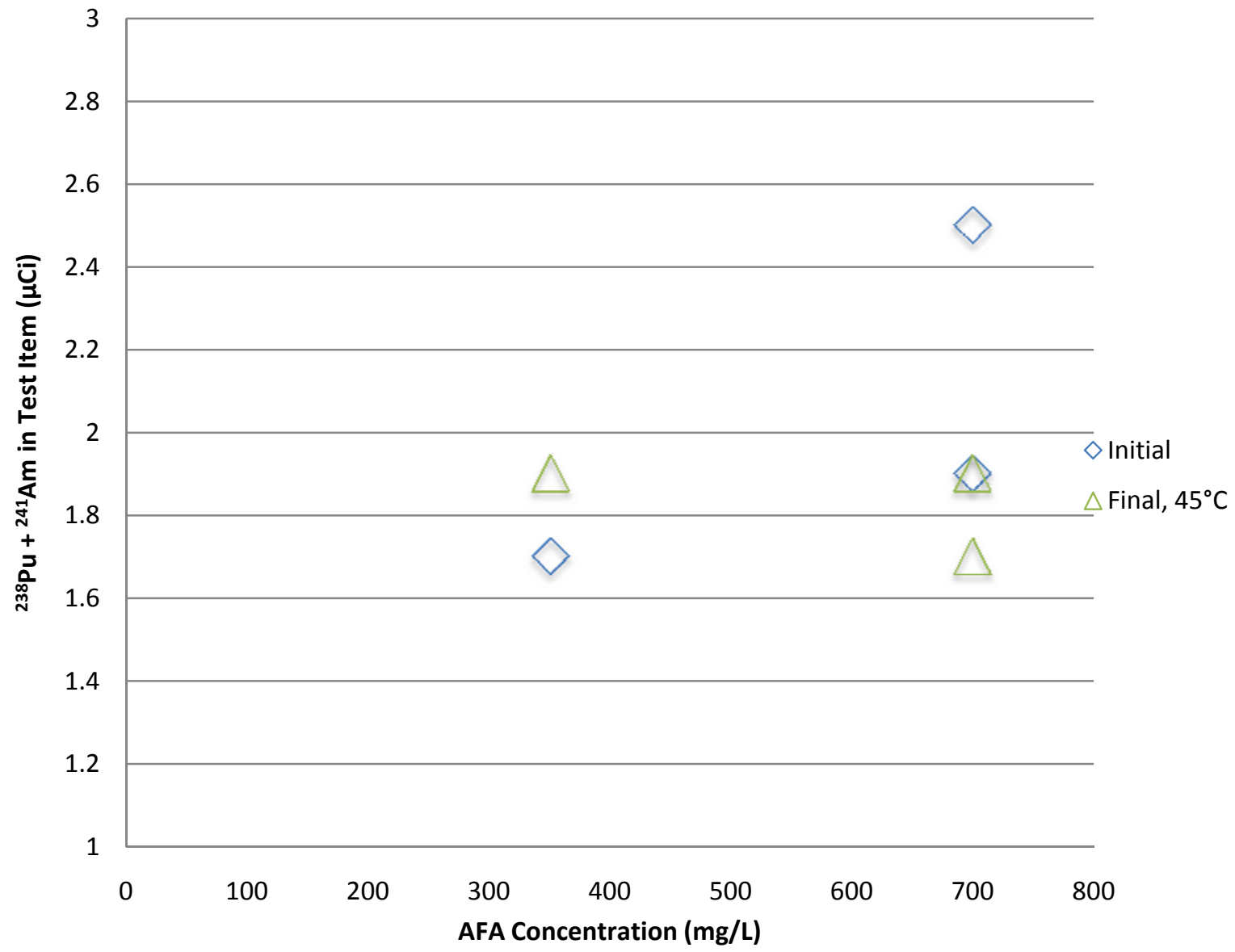

Figure 3.24. Quantity of ${ }^{238} \mathrm{Pu}+{ }^{241} \mathrm{Am}$ in the Solids Before Oxidative Leaching (Initial) and After Oxidative Leaching (Final) at $45^{\circ} \mathrm{C}$ 
Although plutonium and americium were not analyzed separately, by comparing the results for ${ }^{239+240} \mathrm{Pu}$ with the results for ${ }^{238} \mathrm{Pu}+{ }^{241} \mathrm{Am}$ any differences in behavior of americium compared to plutonium may be inferred. In Figure 3.25, The fraction of ${ }^{239+240} \mathrm{Pu}$ removed plotted against the fraction of ${ }^{238} \mathrm{Pu}+{ }^{241} \mathrm{Am}$ removed yields a straight line with a slope of 0.7 . If the plutonium and americium were removed equally, one would expect a slope of 1.0, therefore, these data indicate plutonium is preferentially removed and more of the americium remains with the solids.

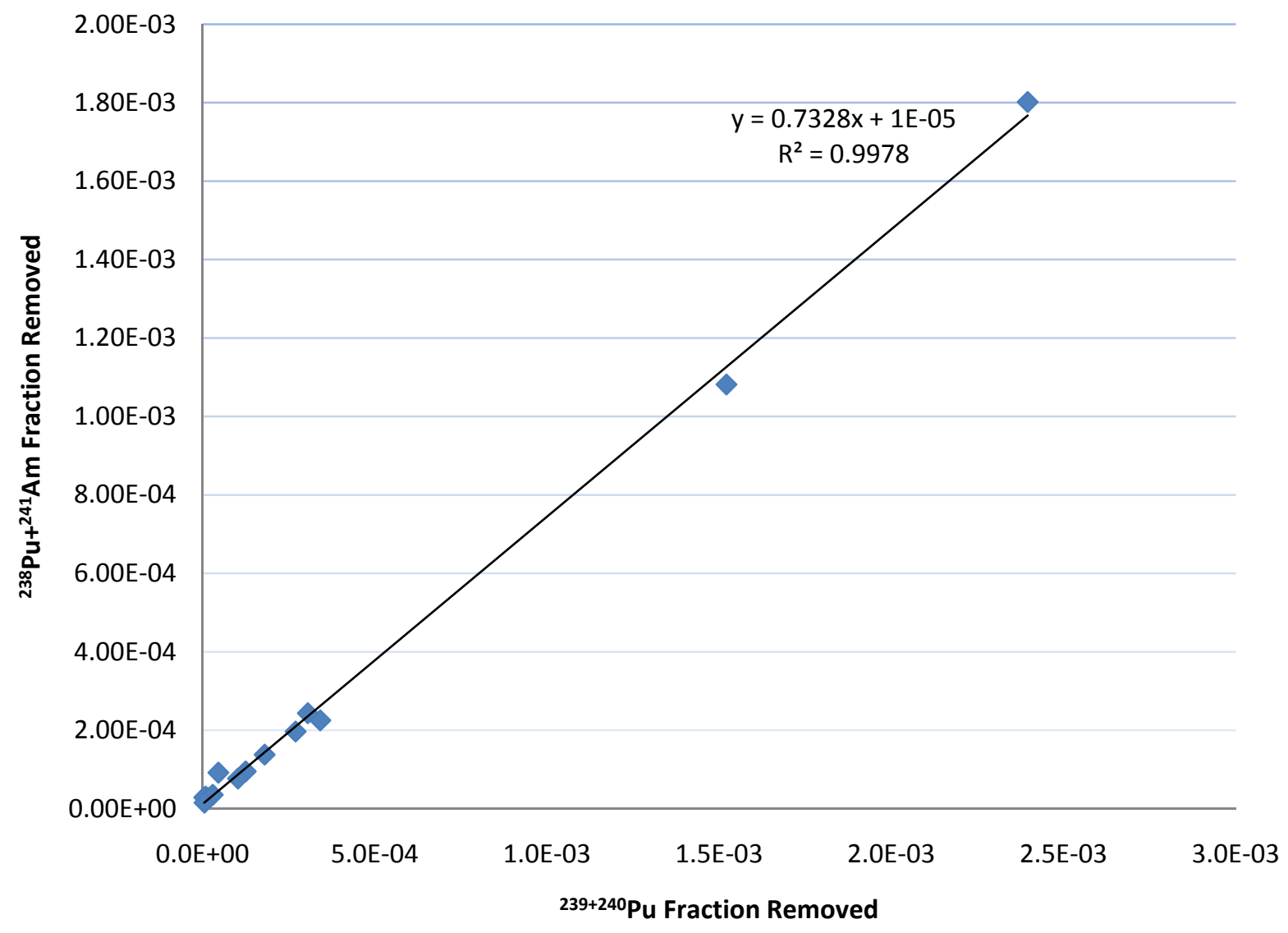

Figure 3.25. Relationship Between ${ }^{239+240} \mathrm{Pu}$ and ${ }^{238} \mathrm{Pu}+{ }^{241} \mathrm{Am}$ Removal by Oxidative Leaching 


\subsubsection{Combined Results Comparisons}

Comparisons of analytical results for analytical laboratory duplicate samples of the final oxidatively leached solids in Table 3.23 demonstrate that interpreting the results must take into consideration the range of values that may be reported for seemingly homogeneous samples. These duplicates were samples of the final solids after oxidative-leach that were divided in the analytical laboratory and prepared separately. The most extreme example of differences in results for these samples is seen in the uranium results where duplicate samples from Test 5 differ by $44 \%$ while there is $0 \%$ difference between the Test 10 duplicates.

Table 3.23. Comparison of Analytical Results for Key Components on Duplicate Samples of Final Dried Solids After Oxidative Leaching

\begin{tabular}{ccccccc}
\hline & & & & & & \\
Sample & $(\text { Analyte })^{(\mathrm{a})}$ & $\mathrm{Cr}$ & $\mathrm{Fe}$ & $\mathrm{Mn}$ & $\mathrm{U}$ & $\mathrm{Zn}$ \\
\hline AFA-Test-5-OL-S & $(\mu \mathrm{g} / \mathrm{g})$ & 6,300 & 262,000 & 203,000 & 13,900 & 1,950 \\
& $(\mu \mathrm{g} / \mathrm{g})$ & 7,250 & 255,000 & 190,000 & 21,700 & 2,020 \\
& $\mathrm{RPD}$ & $14.0 \%$ & $2.7 \%$ & $6.6 \%$ & $43.8 \%$ & $3.5 \%$ \\
\hline AFA-Test-10-OL-S & $(\mu \mathrm{g} / \mathrm{g})$ & 6,740 & 245,000 & 192,000 & 28,400 & 2,370 \\
& $(\mu \mathrm{g} / \mathrm{g})$ & 6,160 & 247,000 & 202,000 & 28,400 & 2,370 \\
& $\mathrm{RPD}$ & $9.0 \%$ & $0.8 \%$ & $5.1 \%$ & $0.0 \%$ & $0.0 \%$ \\
\hline
\end{tabular}

(a) Ni was not reported because Ni crucibles were used in the analytical fusions procedure to dissolve solid samples for analysis.

Analysis results of the washed and dried residual solids following oxidative leaching are shown in Table 3.24. 
Table 3.24. Amounts of Key Components in Final Washed and Dried Residual Solids Following Oxidative Leaching with Permanganate

\begin{tabular}{rcccccccc}
\hline & $\begin{array}{c}\text { AFA } \\
\text { added } \\
(\mathrm{mg} / \mathrm{L})\end{array}$ & $\begin{array}{c}\mathrm{Cr} \\
(\mu \mathrm{g})\end{array}$ & $\begin{array}{c}\mathrm{Fe} \\
(\mu \mathrm{g})\end{array}$ & $\begin{array}{c}\mathrm{Mn} \\
(\mu \mathrm{g})\end{array}$ & $\begin{array}{c}\mathrm{Ni}^{(\mathrm{a})} \\
(\mu \mathrm{g})\end{array}$ & $\begin{array}{c}\mathrm{U} \\
(\mu \mathrm{g})\end{array}$ & $\begin{array}{c}{ }^{239+240} \mathrm{Pu} \\
(\mu \mathrm{Ci})\end{array}$ & $\begin{array}{c}{ }^{241} \mathrm{Am}+ \\
(\mu \mathrm{Ci})\end{array}$ \\
\hline 1 & 175 & 90,000 & 790,000 & 560,000 & 30,000 & 46,000 & 60 & 1.8 \\
2 & 350 & 110,000 & 680,000 & 500,000 & 30,000 & 44,000 & 62 & 1.6 \\
3 & 350 & 65,000 & 760,000 & 570,000 & 30,000 & 43,000 & 65 & 1.8 \\
$4 \mathrm{a}$ & 700 & 68,000 & 830,000 & 620,000 & 30,000 & 59,000 & 63 & 1.8 \\
$4 \mathrm{~b}$ & 700 & 81,000 & 740,000 & 560,000 & 30,000 & 43,000 & 70 & 1.9 \\
$4 \mathrm{c}$ & 700 & 26,000 & 760,000 & 590,000 & 30,000 & 97,000 & 73 & 1.9 \\
5 & 350 & 19,000 & 790,000 & 610,000 & 30,000 & 42,000 & 75 & 1.9 \\
6 & 700 & 24,000 & 700,000 & 600,000 & 30,000 & 99,000 & 73 & 1.7 \\
7 & 350 & 27,000 & 760,000 & 600,000 & 30,000 & 71,000 & 77 & 1.9 \\
$8 \mathrm{a}$ & 0 & 24,000 & 750,000 & 590,000 & 30,000 & 72,000 & 70 & 1.7 \\
$8 \mathrm{~b}$ & 0 & 27,000 & 780,000 & 600,000 & 30,000 & 71,000 & 72 & 1.8 \\
$8 \mathrm{c}$ & 0 & 22,000 & 590,000 & 650,000 & 30,000 & 110,000 & 68 & 1.8 \\
9 & 700 & 31,000 & 810,000 & 610,000 & 30,000 & 42,000 & 74 & 1.9 \\
10 & 700 & 21,000 & 750,000 & 590,000 & 30,000 & 87,000 & 73 & 1.8 \\
\hline
\end{tabular}

(a) Ni crucibles were used in the analytical fusions procedure to dissolve solids samples for analysis. These values are calculated based on simulant makeup and solution analyses.

Two triplicate samples (total six test items) were tested to determine variability in the method. These triplicates were test items $4 \mathrm{a}-\mathrm{c}$ that contained AFA at the $700 \mathrm{ppm}$ level and items 8a-c that contained no AFA. Results, averages, standard deviations, and relative standard deviations for each of the elements of interest in the test item solids leached with $3 \mathrm{M} \mathrm{NaOH}$ and then permanganate are shown in Table 3.25. 
Table 3.25. Statistical Analysis of Triplicate Test Items at Two AFA Concentration Levels

\begin{tabular}{|c|c|c|c|c|c|c|c|c|}
\hline \multirow[b]{2}{*}{$\begin{array}{c}\text { AFA } \\
\text { Level } \\
(\mathrm{mg} / \mathrm{L})\end{array}$} & & \multicolumn{7}{|c|}{ Quantities Measured in Final Supernate } \\
\hline & & $\begin{array}{c}\mathrm{Cr} \\
(\mu \mathrm{g})\end{array}$ & $\begin{array}{c}\mathrm{Fe} \\
(\mu \mathrm{g})\end{array}$ & $\begin{array}{l}\mathrm{Mn} \\
(\mu \mathrm{g})\end{array}$ & \multirow{2}{*}{$\begin{array}{c}\begin{array}{c}\mathrm{U} \\
(\mu \mathrm{g})\end{array} \\
680\end{array}$} & $\begin{array}{c}\mathrm{Zn} \\
(\mu \mathrm{g})\end{array}$ & $\begin{array}{c}{ }^{239+240} \mathrm{Pu} \\
(\mu \mathrm{Ci})\end{array}$ & $\begin{array}{c}{ }^{238} \mathrm{Pu}+ \\
{ }^{241} \mathrm{Am} \\
(\mu \mathrm{Ci})\end{array}$ \\
\hline & Average & 580,000 & 33 & 1,400 & & & $8.0 \mathrm{E}-03$ & $1.7 \mathrm{E}-04$ \\
\hline & Stdev & 24,000 & 4 & 2,400 & 350 & & $1.3 \mathrm{E}-02$ & 2.1E-04 \\
\hline 0 & RSD & $4.2 \%$ & $11.2 \%$ & $170 \%$ & $52 \%$ & & $163.6 \%$ & $120.9 \%$ \\
\hline \multirow{4}{*}{700} & Average & 560,000 & 40 & $<1.0$ & 930 & $<18$ & $3.6 \mathrm{E}-03$ & $1.2 \mathrm{E}-04$ \\
\hline & Stdev & 22,000 & 14 & & 410 & & $2.6 \mathrm{E}-03$ & $6.1 \mathrm{E}-05$ \\
\hline & RSD & $3.9 \%$ & $34.0 \%$ & & $3.9 \%$ & & $71.3 \%$ & $51.3 \%$ \\
\hline & & \multicolumn{7}{|c|}{ Quantities Measured in Final Solids } \\
\hline $\begin{array}{c}\text { AFA } \\
\text { Level } \\
(\mathrm{mg} / \mathrm{L}) \\
\end{array}$ & & $\begin{array}{c}\mathrm{Cr} \\
(\mu \mathrm{g})\end{array}$ & $\begin{array}{c}\mathrm{Fe} \\
(\mu \mathrm{g})\end{array}$ & $\begin{array}{l}\mathrm{Mn} \\
(\mu \mathrm{g})\end{array}$ & $\begin{array}{c}\mathrm{U} \\
(\mu \mathrm{g})\end{array}$ & $\begin{array}{c}\mathrm{Zn} \\
(\mu \mathrm{g})\end{array}$ & $\begin{array}{c}{ }^{239+240} \mathrm{Pu} \\
(\mu \mathrm{Ci})\end{array}$ & $\begin{array}{c}{ }^{238} \mathrm{Pu}+ \\
{ }^{241} \mathrm{Am} \\
(\mu \mathrm{Ci}) \\
\end{array}$ \\
\hline \multirow{5}{*}{0} & Average & 24,000 & 710,000 & 610,000 & 84,381 & 5,700 & 70 & 1.8 \\
\hline & Stdev & 2,700 & 98,000 & 33,000 & 22,881 & 550 & 2 & 0.04 \\
\hline & RSD & $11 \%$ & $14 \%$ & $5.4 \%$ & $27 \%$ & $9.7 \%$ & $2.8 \%$ & $2.3 \%$ \\
\hline & Average & 58,394 & 780,000 & 590,000 & 66,081 & 5,700 & 23 & 1.9 \\
\hline & Stdev & 28,555 & 44,000 & 34,000 & 27,613 & 540 & 2 & 0.08 \\
\hline 700 & RSD & $48.9 \%$ & $5.7 \%$ & $6 \%$ & $42 \%$ & $9.5 \%$ & $7.8 \%$ & $4.3 \%$ \\
\hline
\end{tabular}




\subsection{Summary and Conclusions}

The work described in this report involved testing a $\mathrm{Cr}$ (III)-containing simulant for conversion from $\mathrm{Cr}(\mathrm{III})$ to $\mathrm{Cr}(\mathrm{VI})$ by contact with alkaline solutions containing permanganate in the presence of AFA. The ultimate goal of this work was to determine if the amount of permanganate required to oxidize $\mathrm{Cr}(\mathrm{III})$ needs to be adjusted for the presence of AFA because some of the permanganate may be consumed by oxidizing the organic material in the AFA.

A radioactive simulant containing oxides or hydroxides of chromium, manganese, nickel, zinc, uranium, and plutonium was prepared and characterized. Aliquots of the simulant were adjusted to $3 \mathrm{M} \mathrm{NaOH}$ for a caustic-leach ratio of 3:1 leachate to settled-solids volume. AFA was added to the test items at dosing rates of 0 to $700 \mathrm{mg}$ AFA per liter of settled solids. The solids were leached first with caustic at $85 \pm 5^{\circ} \mathrm{C}$, the leachate was removed, and then the solids were washed with dilute caustic solution. The remaining solids underwent oxidative leaching with permanganate at a molar ratio of 1.0 permanganate to $\mathrm{Cr}(\mathrm{III})$. The temperatures for oxidative-leach were $25^{\circ} \mathrm{C}$ or $45^{\circ} \mathrm{C}$. Samples of leachate plus washes and residual solids were analyzed at each stage of testing.

The distribution of chromium between simulant waste slurry and the supernate liquids for all caustic and oxidative leaching tests is summarized in Table 4.1. The fraction of chromium remaining in the solids is less than $20 \%$ for all tests. These data are presented in Table 4.2. There was some chromium initially soluble. The quantity of soluble chromium did not increase significantly during caustic leaching. The final oxidative-leach shows increased chromium in the liquid with increasing AFA concentration.

For the key elements related to criticality safety, iron, manganese, and nickel, no AFA effects were observed. The radioactive elements in this study were uranium, plutonium, and americium and showed no effects that could be attributed to AFA. The conclusion from these experiments is that there are no AFA effects on caustic-leach or oxidative-leach. 
Table 4.1. Chromium Distribution Between Liquid and Solid for Each Phase of Testing

\begin{tabular}{|c|c|c|c|c|c|c|c|}
\hline \multirow[b]{3}{*}{ Test } & \multirow[b]{3}{*}{$\begin{array}{c}\text { AFA } \\
\text { added } \\
(\mathrm{mg} / \mathrm{L})\end{array}$} & \multicolumn{6}{|c|}{ Weight Fraction $\mathrm{Cr}$} \\
\hline & & \multicolumn{2}{|c|}{ Initial } & \multicolumn{2}{|c|}{ After Caustic-Leach } & \multicolumn{2}{|c|}{ After Oxidative-Leach } \\
\hline & & $\begin{array}{l}\text { Initial } \\
\text { Liquid, } \\
25^{\circ} \mathrm{C}\end{array}$ & $\begin{array}{l}\text { Initial } \\
\text { Solid, } \\
25^{\circ} \mathrm{C}\end{array}$ & $\begin{array}{c}\text { After CL } \\
\text { Liquid, } \\
25^{\circ} \mathrm{C}\end{array}$ & $\begin{array}{c}\text { After CL } \\
\text { Solid, } \\
25^{\circ} \mathrm{C}\end{array}$ & $\begin{array}{c}\text { After OL } \\
\text { Liquid, } \\
25^{\circ} \mathrm{C}\end{array}$ & $\begin{array}{l}\text { Final } \\
\text { Solid, } \\
25^{\circ} \mathrm{C}\end{array}$ \\
\hline $8 \mathrm{a}$ & 0 & 0.004 & 0.996 & 0.009 & 0.991 & 0.860 & 0.140 \\
\hline $8 b$ & 0 & 0.004 & 0.996 & 0.010 & 0.990 & 0.826 & 0.174 \\
\hline $8 \mathrm{c}$ & 0 & 0.003 & 0.997 & 0.010 & 0.990 & 0.895 & 0.105 \\
\hline 1 & 175 & 0.003 & 0.997 & 0.006 & 0.994 & 0.891 & 0.109 \\
\hline 2 & 350 & 0.003 & 0.997 & 0.007 & 0.993 & 0.871 & 0.129 \\
\hline 5 & 350 & 0.003 & 0.997 & 0.008 & 0.992 & 0.957 & 0.043 \\
\hline $4 a$ & 700 & 0.003 & 0.997 & 0.009 & 0.991 & 0.970 & 0.030 \\
\hline $4 \mathrm{~b}$ & 700 & 0.003 & 0.997 & 0.007 & 0.993 & 0.962 & 0.038 \\
\hline $4 c$ & 700 & 0.003 & 0.997 & 0.007 & 0.993 & 0.957 & 0.043 \\
\hline 10 & 700 & 0.003 & 0.997 & 0.006 & 0.994 & 0.962 & 0.038 \\
\hline Test & $\begin{array}{c}\text { AFA } \\
\text { added } \\
(\mathrm{mg} / \mathrm{L})\end{array}$ & $\begin{array}{c}\text { Initial } \\
\text { Liquid, } \\
45^{\circ} \mathrm{C}\end{array}$ & $\begin{array}{l}\text { Initial } \\
\text { Solid, } \\
45^{\circ} \mathrm{C}\end{array}$ & $\begin{array}{c}\text { After CL } \\
\text { Liquid, } \\
45^{\circ} \mathrm{C}\end{array}$ & $\begin{array}{c}\text { After CL } \\
\text { Solid, } \\
45^{\circ} \mathrm{C}\end{array}$ & $\begin{array}{c}\text { After OL } \\
\text { Liquid, } \\
45^{\circ} \mathrm{C}\end{array}$ & $\begin{array}{l}\text { Final } \\
\text { Solid, } \\
45^{\circ} \mathrm{C}\end{array}$ \\
\hline 3 & 350 & 0.004 & 0.996 & 0.008 & 0.992 & 0.957 & 0.043 \\
\hline 7 & 350 & 0.004 & 0.996 & 0.008 & 0.992 & 0.962 & 0.038 \\
\hline 9 & 700 & 0.003 & 0.997 & 0.008 & 0.992 & 0.950 & 0.050 \\
\hline 6 & 700 & 0.003 & 0.997 & 0.006 & 0.994 & 0.966 & 0.034 \\
\hline
\end{tabular}


Table 4.2. Summary of Cr Removal by Oxidative-Leach Tests

\begin{tabular}{ccccccc}
\hline \multicolumn{1}{c}{$\begin{array}{c}\text { AFA } \\
\text { Added, } \\
\text { Temperature }\end{array}$} & $\begin{array}{c}\text { Fraction } \\
\text { Cr } \\
\text { Removed }\end{array}$ & $\begin{array}{c}\text { Data } \\
\text { Points }\end{array}$ & Average & Stdev & RSD \\
\hline $25^{\circ} \mathrm{C}$ & 0 & 0.95 & & & & \\
$25^{\circ} \mathrm{C}$ & 0 & 0.96 & & & & \\
$25^{\circ} \mathrm{C}$ & 0 & 0.96 & $3 @ 25,0$ & 0.96 & 0.0042 & $0.44 \%$ \\
$25^{\circ} \mathrm{C}$ & 175 & 0.83 & $1 @ 25,175$ & 0.83 & $\mathrm{NA}$ & $\mathrm{NA}$ \\
$25^{\circ} \mathrm{C}$ & 350 & 0.79 & $2 @ 25$, & & & \\
$25^{\circ} \mathrm{C}$ & 350 & 0.89 & 350 & 0.84 & 0.066 & $7.9 \%$ \\
$25^{\circ} \mathrm{C}$ & 700 & 0.86 & & & & \\
$25^{\circ} \mathrm{C}$ & 700 & 0.88 & & & & \\
$25^{\circ} \mathrm{C}$ & 700 & 0.95 & $4 @ 25$, & & & \\
$25^{\circ} \mathrm{C}$ & 700 & 0.96 & 700 & 0.91 & 0.052 & $5.7 \%$ \\
$45^{\circ} \mathrm{C}$ & 350 & 0.95 & $2 @ 45$, & & & \\
$45^{\circ} \mathrm{C}$ & 350 & 0.97 & 350 & 0.96 & 0.011 & $1.1 \%$ \\
$45^{\circ} \mathrm{C}$ & 700 & 0.96 & $2 @ 45$, & & & \\
$45^{\circ} \mathrm{C}$ & 700 & 0.97 & 700 & 0.96 & 0.0093 & $0.96 \%$ \\
\hline $\mathrm{NA}=\mathrm{Not}$ Applicable & & & & \\
\hline
\end{tabular}





\subsection{References}

Jeffery GH, J Bassett, J Mendham, and RC Denny. 1989. Vogel's Textbook of Quantitative Inorganic Chemistry, $5^{\text {th }}$ Edition. Longman Group UK Limited, Essex, England.

Rapko BM, JGH Geeting, SI Sinkov, and JD Vienna. 2004. Oxidative-Alkaline Leaching of Washed 241-SY-102 and 241-SX-101 Tank Sludges. PNWD-3512, WTP-RPT-117, Battelle-Pacific Northwest Division, Richland, Washington.

Rapko BM, GJ Lumetta, JD Vienna, and SK Fiskum. 2005. Oxidative Alkaline Leaching of SX-101 and SY-102 and Its Impact on Immobilized High-Level Waste. PNWD-3600, WTP-RPT-137, Battelle-Pacific Northwest Division, Richland, Washington.

Rapko BM, GJ Lumetta, JR Deschane, and RA Peterson. 2007. Process Development for Permanganate Addition During Oxidative Leaching of Hanford Sludge Simulants. PNNL-16794, WTP-RPT-164, Pacific Northwest National Laboratory, Richland, Washington.

Sinkov SI. 2007. Plutonium Speciation in Support of Oxidative Leaching Demonstration Test. PNNL-16844, WTP-RPT-165, Pacific Northwest National Laboratory, Richland, Washington. 



\section{Appendix A}

\section{Email Note from $F$ Damerow (BNI) to RA Peterson (PNNL) Directing PNNL to Not Test Actual Waste}





\section{Appendix A: Email Note from F Damerow (BNI) to RA Peterson (PNNL) Directing PNNL to Not Test Actual Waste}

From: Damerow, Frederick (WGI) [mailto:fwdamero@bechtel.com]

Sent: Friday, May 08, 2009 8:21 AM

To: Peterson, Reid A

Cc: Sundar, Parameshwaran S; Beeman, Gordon H; Jao, J uai C

Subject: Oxidative Leach Actual Waste Testing

Sundar and I discussed the benefit of the actual waste testing this morning. Based on that and our conversation yesterday, I don't believe we there is enough value to justify the work. Let's proceed to develop the letter report and close-out the scope.

Fred Damerow

R\&T Systems and Pretreatment Manager

fwdamero@bechtel.com

off 509-371-3613

cell 509-531-5538

MPF B268 



\section{Appendix B}

Details Related to Radioactive Simulant Leaching Testing 



\section{Appendix B: Details Related to Radioactive Simulant Leaching Testing}

The methodology of this approach is as follows: the reported analytical results were multiplied by two dilution factors to obtain the reported estimates for the actual component solution concentrations. The first dilution factor was the dilution made from the combined solution and washes aliquot into a known volume of $1 \mathrm{M}$ nitric acid. This was done to prevent any component precipitations from the time of assay until the time of analysis. The second dilution factor represents the dilution of the leachate solutions by wash solution to get the actual assayed solutions. This dilution factor was obtained by comparing the targeted total solution volume to the actual recovered volume of wash solution and leachate. It should be noted that the targeted solution for the caustic leachate also contains some unknown contribution because of the volume of the centrifuged solids themselves. For this reason, these values should be considered as estimates.

Table B.1. Experimental Information for Leach Tests

\begin{tabular}{|c|c|c|c|c|c|c|c|}
\hline Test & $\begin{array}{l}\text { Solids/ } \\
\text { Test (g) }\end{array}$ & $\begin{array}{l}\text { Mass CL \& } \\
\text { Washes (g) }\end{array}$ & $\begin{array}{l}\text { Density } \\
\text { CL \& } \\
\text { Washes } \\
(\mathrm{g} / \mathrm{mL})\end{array}$ & $\begin{array}{c}\text { CL Test } \\
\text { Temperature } \\
\left({ }^{\circ} \mathrm{C}\right)\end{array}$ & $\begin{array}{l}\text { Mass OL \& } \\
\text { Washes (g) }\end{array}$ & $\begin{array}{c}\text { Density } \\
\text { OL \& } \\
\text { Washes } \\
(\mathrm{g} / \mathrm{mL})\end{array}$ & $\begin{array}{c}\text { OL Test } \\
\text { Temperature } \\
\left({ }^{\circ} \mathrm{C}\right)\end{array}$ \\
\hline 1 & 3.280 & 265.355 & 1.079 & $85 \pm 5$ & 280.347 & 1.022 & $25 \pm 1$ \\
\hline 2 & 3.198 & 269.861 & 1.079 & $85 \pm 5$ & 273.982 & 1.015 & $25 \pm 1$ \\
\hline 3 & 3.240 & 270.187 & 1.098 & $85 \pm 5$ & 280.963 & 1.014 & $25 \pm 1$ \\
\hline $4 a$ & 3.223 & 293.408 & 1.077 & $85 \pm 5$ & 279.221 & 1.015 & $25 \pm 1$ \\
\hline $4 \mathrm{~b}$ & 3.229 & 243.719 & 1.070 & $85 \pm 5$ & 290.138 & 1.010 & $25 \pm 1$ \\
\hline $4 c$ & 3.240 & 267.683 & 1.086 & $85 \pm 5$ & 265.477 & 1.013 & $25 \pm 1$ \\
\hline 5 & 3.186 & 265.576 & 1.077 & $85 \pm 5$ & 303.347 & 1.015 & $45 \pm 1$ \\
\hline 6 & 3.222 & 265.803 & 1.076 & $85 \pm 5$ & 300.215 & 1.012 & $45 \pm 1$ \\
\hline 7 & 3.190 & 238.004 & 1.081 & $85 \pm 5$ & 300.402 & 1.011 & $45 \pm 1$ \\
\hline $8 a$ & 3.211 & 267.978 & 1.075 & $85 \pm 5$ & 265.446 & 1.010 & $25 \pm 1$ \\
\hline $8 b$ & 3.227 & 242.607 & 1.078 & $85 \pm 5$ & 261.274 & 1.016 & $25 \pm 1$ \\
\hline $8 \mathrm{c}$ & 3.189 & 253.102 & 1.079 & $85 \pm 5$ & 271.641 & 1.013 & $25 \pm 1$ \\
\hline 9 & 3.230 & 228.541 & 1.083 & $85 \pm 5$ & 293.665 & 1.014 & $45 \pm 1$ \\
\hline 10 & 3.189 & 253.594 & 1.078 & $85 \pm 5$ & 265.823 & 1.010 & $25 \pm 1$ \\
\hline
\end{tabular}


Table B.2. Metals Analysis for Initial Equilibrated Supernatant Solution ${ }^{(a)}$

\begin{tabular}{|c|c|c|c|c|c|c|c|c|c|c|c|c|c|}
\hline Sample Number & (Analyte) & $\mathrm{Al}$ & $\mathrm{Cr}$ & $\mathrm{Fe}$ & $\mathrm{P}$ & $\mathrm{Si}$ & $\mathrm{Ag}$ & As & $\mathrm{B}$ & $\mathrm{Ba}$ & $\mathrm{Be}$ & $\mathrm{Bi}$ & $\mathrm{Ca}$ \\
\hline AFA-Test 1-CLI-M & $(\mu \mathrm{g} / \mathrm{mL})$ & {$[3.3]$} & 17 & {$[0.12]$} & $<6.6$ & 69 & $<0.14$ & $<18$ & 34 & {$[0.33]$} & $<0.01$ & $<2.9$ & {$[1.5]$} \\
\hline AFA-Test 2-CLI-M & $(\mu \mathrm{g} / \mathrm{mL})$ & {$[3.3]$} & 17 & {$[0.20]$} & $<6.6$ & 72 & {$[0.20]$} & $<18$ & 35 & {$[0.34]$} & $<0.01$ & $<2.9$ & [1.6] \\
\hline AFA-Test 3-CLI-M & $(\mu \mathrm{g} / \mathrm{mL})$ & {$[3.1]$} & 17 & {$[0.21]$} & $<6.6$ & 70 & $<0.14$ & $<18$ & 34 & {$[0.22]$} & $<0.01$ & $<2.9$ & {$[0.97]$} \\
\hline AFA-Test 4a-CLI-M & $(\mu \mathrm{g} / \mathrm{mL})$ & {$[3.0]$} & 16 & {$[0.26]$} & $<6.6$ & 77 & $<0.14$ & $<18$ & 32 & {$[0.33]$} & $<0.01$ & $<2.9$ & [0.99] \\
\hline AFA-Test 4b-CLI-M & $(\mu \mathrm{g} / \mathrm{mL})$ & [2.9] & 16 & {$[0.17]$} & $<6.6$ & 79 & $<0.14$ & $<18$ & 34 & {$[0.35]$} & $<0.01$ & $<2.9$ & {$[1.1]$} \\
\hline AFA-Test 4c-CLI-M & $(\mu \mathrm{g} / \mathrm{mL})$ & {$[2.2]$} & 17 & {$[0.16]$} & $<6.6$ & 73 & $<0.14$ & $<18$ & 28 & {$[0.14]$} & $<0.01$ & $<2.9$ & {$[0.98]$} \\
\hline AFA-Test 5-CLI-M & $(\mu \mathrm{g} / \mathrm{mL})$ & {$[3.3]$} & 16 & {$[0.25]$} & $<6.6$ & 83 & $<0.14$ & $<18$ & 36 & {$[0.25]$} & $<0.01$ & $<2.9$ & {$[0.74]$} \\
\hline AFA-Test 6-CLI-M & $(\mu \mathrm{g} / \mathrm{mL})$ & {$[3.1]$} & 16 & $<0.100$ & $<6.6$ & 83 & $<0.14$ & $<18$ & 36 & {$[0.26]$} & $<0.01$ & $<2.9$ & {$[1.6]$} \\
\hline AFA-Test 7-CLI-M & $(\mu \mathrm{g} / \mathrm{mL})$ & {$[3.1]$} & 17 & {$[0.14]$} & $<6.6$ & 87 & $<0.14$ & $<18$ & 36 & {$[0.21]$} & $<0.01$ & $<2.9$ & {$[1.5]$} \\
\hline AFA-Test 8a-CLI-M & $(\mu \mathrm{g} / \mathrm{mL})$ & {$[3.3]$} & 16 & {$[0.14]$} & $<6.6$ & 74 & $<0.14$ & $<18$ & 36 & {$[0.22]$} & $<0.01$ & $<2.9$ & {$[1.2]$} \\
\hline AFA-Test 8b-CLI-M & $(\mu \mathrm{g} / \mathrm{mL})$ & {$[3.1]$} & 17 & {$[0.15]$} & $<6.6$ & 65 & $<0.14$ & $<18$ & 36 & {$[0.20]$} & $<0.01$ & $<2.9$ & {$[1.0]$} \\
\hline AFA-Test 8c-CLI-M & $(\mu \mathrm{g} / \mathrm{mL})$ & {$[2.7]$} & 17 & {$[0.16]$} & $<6.6$ & 68 & {$[0.19]$} & $<18$ & 35 & {$[0.20]$} & $<0.01$ & $<2.9$ & {$[1.3]$} \\
\hline AFA-Test 9-CLI-M & $(\mu \mathrm{g} / \mathrm{mL})$ & {$[2.8]$} & 17 & {$[0.14]$} & $<6.6$ & 66 & $<0.14$ & $<18$ & 26 & {$[0.20]$} & $<0.01$ & $<2.9$ & {$[1.3]$} \\
\hline AFA-Test 10-CLI-M & $(\mu \mathrm{g} / \mathrm{mL})$ & {$[3.2]$} & 17 & $<0.1$ & $<6.6$ & 86 & $<0.14$ & $<18$ & 39 & {$[0.26]$} & $<0.01$ & $<2.9$ & [1.7] \\
\hline
\end{tabular}

(a) Values in brackets [] are $\geq$ the method detection limit, but are $<$ the estimated quantitation limit, with errors likely to exceed $15 \%$. 
Table B.2 (contd) $)^{(\mathrm{a})}$

\begin{tabular}{|c|c|c|c|c|c|c|c|c|c|c|c|c|c|}
\hline & (Analyte) & $\mathrm{Cd}$ & $\mathrm{Ce}$ & $\mathrm{Co}$ & $\mathrm{Cu}$ & Dy & $\mathrm{Eu}$ & $\mathrm{K}$ & $\mathrm{La}$ & $\mathrm{Li}$ & $\mathrm{Mg}$ & $\mathrm{Mn}$ & Mo \\
\hline AFA-Test 1-CLI-M & $(\mu \mathrm{g} / \mathrm{mL})$ & $<0.28$ & $<0.67$ & $<0.34$ & $<0.21$ & $<0.22$ & $<0.037$ & {$[18]$} & $<0.21$ & $<0.07$ & $<0.13$ & $<0.02$ & $<1.0$ \\
\hline AFA-Test 2-CLI-M & $(\mu \mathrm{g} / \mathrm{mL})$ & $<0.28$ & $<0.67$ & $<0.34$ & $<0.21$ & $<0.22$ & $<0.037$ & [29] & $<0.21$ & $<0.07$ & $<0.13$ & $<0.02$ & $<1.0$ \\
\hline AFA-Test 3-CLI-M & $(\mu \mathrm{g} / \mathrm{mL})$ & $<0.28$ & {$[0.92]$} & $<0.34$ & $<0.21$ & $<0.22$ & $<0.037$ & {$[36]$} & $<0.21$ & $<0.07$ & $<0.13$ & $<0.02$ & $<1.0$ \\
\hline AFA-Test 4a-CLI-M & $(\mu \mathrm{g} / \mathrm{mL})$ & $<0.28$ & $<0.67$ & $<0.34$ & $<0.21$ & $<0.22$ & $<0.037$ & 73 & $<0.21$ & {$[0.39]$} & $<0.13$ & $<0.02$ & $<1.0$ \\
\hline AFA-Test 4b-CLI-M & $(\mu \mathrm{g} / \mathrm{mL})$ & $<0.28$ & $<0.67$ & $<0.34$ & $<0.21$ & $<0.22$ & $<0.037$ & {$[48]$} & $<0.21$ & $<0.07$ & $<0.13$ & $<0.02$ & $<1.0$ \\
\hline AFA-Test 4c-CLI-M & $(\mu \mathrm{g} / \mathrm{mL})$ & $<0.28$ & $<0.67$ & $<0.34$ & $<0.21$ & $<0.22$ & $<0.037$ & [47] & $<0.21$ & $<0.07$ & $<0.13$ & $<0.02$ & $<1.0$ \\
\hline AFA-Test 5-CLI-M & $(\mu \mathrm{g} / \mathrm{mL})$ & $<0.28$ & $<0.67$ & $<0.34$ & $<0.21$ & $<0.22$ & $<0.037$ & 61 & $<0.21$ & $<0.07$ & {$[0.13]$} & $<0.02$ & $<1.0$ \\
\hline AFA-Test 6-CLI-M & $(\mu \mathrm{g} / \mathrm{mL})$ & $<0.28$ & $<0.67$ & $<0.34$ & $<0.21$ & $<0.22$ & $<0.037$ & {$[33]$} & $<0.21$ & $<0.07$ & $<0.13$ & $<0.02$ & $<1.0$ \\
\hline AFA-Test 7-CLI-M & $(\mu \mathrm{g} / \mathrm{mL})$ & $<0.28$ & $<0.67$ & $<0.34$ & $<0.21$ & $<0.22$ & $<0.037$ & [49] & $<0.21$ & $<0.07$ & $<0.13$ & $<0.02$ & $<1.0$ \\
\hline AFA-Test 8a-CLI-M & $(\mu \mathrm{g} / \mathrm{mL})$ & $<0.28$ & {$[1.4]$} & $<0.34$ & $<0.21$ & $<0.22$ & $<0.037$ & [49] & $<0.21$ & $<0.07$ & $<0.13$ & $<0.02$ & $<1.0$ \\
\hline AFA-Test 8b-CLI-M & $(\mu \mathrm{g} / \mathrm{mL})$ & $<0.28$ & $<0.67$ & $<0.34$ & $<0.21$ & $<0.22$ & $<0.037$ & {$[51]$} & $<0.21$ & $<0.07$ & $<0.13$ & $<0.02$ & $<1.0$ \\
\hline AFA-Test 8c-CLI-M & $(\mu \mathrm{g} / \mathrm{mL})$ & $<0.28$ & $<0.67$ & $<0.34$ & $<0.21$ & $<0.22$ & $<0.037$ & [49] & $<0.21$ & $<0.07$ & $<0.13$ & $<0.02$ & $<1.0$ \\
\hline AFA-Test 9-CLI-M & $(\mu \mathrm{g} / \mathrm{mL})$ & $<0.28$ & $<0.67$ & $<0.34$ & $<0.21$ & $<0.22$ & $<0.037$ & {$[56]$} & $<0.21$ & $<0.07$ & {$[0.23]$} & $<0.02$ & $<1.0$ \\
\hline AFA-Test 10-CLI-M & $(\mu \mathrm{g} / \mathrm{mL})$ & $<0.28$ & $<0.67$ & $<0.34$ & $<0.21$ & $<0.22$ & $<0.037$ & {$[55]$} & $<0.21$ & $<0.07$ & $<0.13$ & $<0.02$ & $<1.0$ \\
\hline
\end{tabular}

(a) Values in brackets [] are $\geq$ the method detection limit, but are $<$ the estimated quantitation limit, with errors likely to exceed $15 \%$. 
Table B.2 (contd) $)^{(\mathrm{a})}$

\begin{tabular}{|c|c|c|c|c|c|c|c|c|c|c|c|c|}
\hline & (Analyte) & $\mathrm{Na}$ & $\mathrm{Nd}$ & $\mathrm{Ni}$ & $\mathrm{Pb}$ & $\mathrm{Pd}$ & $\mathrm{Rh}$ & $\mathrm{Ru}$ & $\mathrm{S}$ & $\mathrm{Sb}$ & $\mathrm{Se}$ & $\mathrm{Sn}$ \\
\hline AFA-Test 1-CLI-M & $(\mu \mathrm{g} / \mathrm{mL})$ & {$[73,000]$} & $<0.90$ & $<0.510$ & $<3.4$ & $<0.77$ & $<1.2$ & $<0.97$ & $<12$ & $<3.2$ & $<18$ & {$[4.2]$} \\
\hline AFA-Test 2-CLI-M & $(\mu \mathrm{g} / \mathrm{mL})$ & {$[73,000]$} & {$[1.3]$} & $<0.510$ & $<3.4$ & $<0.77$ & $<1.2$ & $<0.97$ & $<12$ & $<3.2$ & $<18$ & $<3.0$ \\
\hline AFA-Test 3-CLI-M & $(\mu \mathrm{g} / \mathrm{mL})$ & {$[75,000]$} & $<0.90$ & $<0.510$ & $<3.4$ & $<0.77$ & $<1.2$ & $<0.97$ & $<12$ & $<3.2$ & $<18$ & {$[4.2]$} \\
\hline AFA-Test 4a-CLI-M & $(\mu \mathrm{g} / \mathrm{mL})$ & {$[110,000]$} & $<0.90$ & $<0.510$ & $<3.4$ & $<0.77$ & $<1.2$ & $<0.97$ & $<12$ & $<3.2$ & $<18$ & {$[3.8]$} \\
\hline AFA-Test 4b-CLI-M & $(\mu \mathrm{g} / \mathrm{mL})$ & {$[73,000]$} & {$[1.4]$} & $<0.510$ & $<3.4$ & $<0.77$ & $<1.2$ & $<0.97$ & $<12$ & $<3.2$ & $<18$ & $<3.0$ \\
\hline AFA-Test 4c-CLI-M & $(\mu \mathrm{g} / \mathrm{mL})$ & {$[75,000]$} & $<0.90$ & $<0.510$ & $<3.4$ & $<0.77$ & $<1.2$ & $<0.97$ & {$[14]$} & $<3.2$ & $<18$ & $<3.0$ \\
\hline AFA-Test 5-CLI-M & $(\mu \mathrm{g} / \mathrm{mL})$ & {$[86,000]$} & $<0.90$ & $<0.510$ & $<3.4$ & $<0.77$ & $<1.2$ & $<0.97$ & $<12$ & $<3.2$ & $<18$ & $<3.0$ \\
\hline AFA-Test 6-CLI-M & $(\mu \mathrm{g} / \mathrm{mL})$ & {$[74,000]$} & $<0.90$ & $<0.510$ & $<3.4$ & $<0.77$ & $<1.2$ & $<0.97$ & $<12$ & $<3.2$ & $<18$ & {$[4.4]$} \\
\hline AFA-Test 7-CLI-M & $(\mu \mathrm{g} / \mathrm{mL})$ & {$[74,000]$} & $<0.90$ & $<0.510$ & $<3.4$ & {$[0.81]$} & $<1.2$ & $<0.97$ & $<12$ & $<3.2$ & $<18$ & $<3.0$ \\
\hline AFA-Test 8a-CLI-M & $(\mu \mathrm{g} / \mathrm{mL})$ & {$[74,000]$} & {$[1.5]$} & $<0.510$ & $<3.4$ & $<0.77$ & $<1.2$ & $<0.97$ & $<12$ & $<3.2$ & $<18$ & $<3.0$ \\
\hline AFA-Test 8b-CLI-M & $(\mu \mathrm{g} / \mathrm{mL})$ & {$[75,000]$} & $<0.90$ & $<0.510$ & $<3.4$ & $<0.77$ & $<1.2$ & $<0.97$ & $<12$ & $<3.2$ & $<18$ & {$[3.4]$} \\
\hline AFA-Test 8c-CLI-M & $(\mu \mathrm{g} / \mathrm{mL})$ & {$[75,000]$} & {$[0.98]$} & $<0.510$ & $<3.4$ & $<0.77$ & $<1.2$ & $<0.97$ & $<12$ & $<3.2$ & $<18$ & $<3.0$ \\
\hline AFA-Test 9-CLI-M & $(\mu \mathrm{g} / \mathrm{mL})$ & {$[75,000]$} & $<0.90$ & $<0.510$ & $<3.4$ & $<0.77$ & $<1.2$ & $<0.97$ & $<12$ & $<3.2$ & $<18$ & $<3.0$ \\
\hline AFA-Test 10-CLI-M & $(\mu \mathrm{g} / \mathrm{mL})$ & {$[75,000]$} & $<0.90$ & $<0.510$ & $<3.4$ & $<0.77$ & $<1.2$ & $<0.97$ & $<12$ & $<3.2$ & $<18$ & $<3.0$ \\
\hline
\end{tabular}

(a) Values in brackets [] are $\geq$ the method detection limit, but are $<$ the estimated quantitation limit, with errors likely to exceed $15 \%$. 
Table B.2 (contd) $)^{(a)}$

\begin{tabular}{|c|c|c|c|c|c|c|c|c|c|c|c|c|c|}
\hline & (Analyte) & $\mathrm{Sr}$ & $\mathrm{Ta}$ & $\mathrm{Te}$ & Th & $\mathrm{Ti}$ & $\mathrm{Tl}$ & $\mathrm{U}$ & $\mathrm{V}$ & $\mathrm{W}$ & $\mathrm{Y}$ & $\mathrm{Zn}$ & $\mathrm{Zr}$ \\
\hline AFA-Test 1-CLI-M & $(\mu \mathrm{g} / \mathrm{mL})$ & {$[0.01]$} & $<1.6$ & $<2.6$ & $<0.87$ & $<0.046$ & $<9.0$ & {$[22]$} & {$[0.11]$} & $<2.5$ & $<0.034$ & {$[3.1]$} & $<0.12$ \\
\hline AFA-Test 2-CLI-M & $(\mu \mathrm{g} / \mathrm{mL})$ & {$[0.02]$} & $<1.6$ & $<2.6$ & $<0.87$ & $<0.046$ & $<9.0$ & {$[21]$} & {$[0.22]$} & $<2.5$ & $<0.034$ & {$[3.0]$} & $<0.12$ \\
\hline AFA-Test 3-CLI-M & $(\mu \mathrm{g} / \mathrm{mL})$ & {$[0.01]$} & $<1.6$ & $<2.6$ & $<0.87$ & $<0.046$ & $<9.0$ & {$[19]$} & {$[0.11]$} & $<2.5$ & $<0.034$ & {$[2.5]$} & $<0.12$ \\
\hline AFA-Test 4a-CLI-M & $(\mu \mathrm{g} / \mathrm{mL})$ & {$[0.02]$} & $<1.6$ & $<2.6$ & $<0.87$ & $<0.046$ & $<9.0$ & {$[22]$} & {$[0.14]$} & $<2.5$ & $<0.034$ & [2.9] & $<0.12$ \\
\hline AFA-Test 4b-CLI-M & $(\mu \mathrm{g} / \mathrm{mL})$ & {$[0.01]$} & $<1.6$ & $<2.6$ & $<0.87$ & $<0.046$ & $<9.0$ & {$[21]$} & {$[0.19]$} & $<2.5$ & $<0.034$ & {$[2.8]$} & $<0.12$ \\
\hline AFA-Test 4c-CLI-M & $(\mu \mathrm{g} / \mathrm{mL})$ & {$[0.01]$} & $<1.6$ & $<2.6$ & $<0.87$ & $<0.046$ & $<9.0$ & {$[21]$} & {$[0.07]$} & $<2.5$ & $<0.034$ & {$[2.0]$} & $<0.12$ \\
\hline AFA-Test 5-CLI-M & $(\mu \mathrm{g} / \mathrm{mL})$ & {$[0.02]$} & $<1.6$ & $<2.6$ & $<0.87$ & $<0.046$ & $<9.0$ & {$[21]$} & {$[0.18]$} & $<2.5$ & $<0.034$ & {$[2.6]$} & $<0.12$ \\
\hline AFA-Test 6-CLI-M & $(\mu \mathrm{g} / \mathrm{mL})$ & {$[0.02]$} & $<1.6$ & $<2.6$ & $<0.87$ & $<0.046$ & $<9.0$ & [18] & {$[0.10]$} & $<2.5$ & {$[0.04]$} & [1.9] & $<0.12$ \\
\hline AFA-Test 7-CLI-M & $(\mu \mathrm{g} / \mathrm{mL})$ & {$[0.02]$} & $<1.6$ & $<2.6$ & $<0.87$ & $<0.046$ & $<9.0$ & [19] & {$[0.15]$} & $<2.5$ & $<0.034$ & 7.70 & 120 \\
\hline AFA-Test 8a-CLI-M & $(\mu \mathrm{g} / \mathrm{mL})$ & {$[0.01]$} & $<1.6$ & $<2.6$ & $<0.87$ & $<0.046$ & $<9.0$ & {$[21]$} & {$[0.16]$} & $<2.5$ & $<0.034$ & {$[2.2]$} & $<0.12$ \\
\hline AFA-Test 8b-CLI-M & $(\mu \mathrm{g} / \mathrm{mL})$ & {$[0.02]$} & $<1.6$ & $<2.6$ & $<0.87$ & $<0.046$ & $<9.0$ & {$[23]$} & {$[0.20]$} & $<2.5$ & $<0.034$ & {$[2.6]$} & $<0.12$ \\
\hline AFA-Test 8c-CLI-M & $(\mu \mathrm{g} / \mathrm{mL})$ & {$[0.01]$} & $<1.6$ & $<2.6$ & $<0.87$ & $<0.046$ & $<9.0$ & {$[23]$} & {$[0.08]$} & $<2.5$ & $<0.034$ & {$[2.8]$} & $<0.12$ \\
\hline AFA-Test 9-CLI-M & $(\mu \mathrm{g} / \mathrm{mL})$ & {$[0.02]$} & $<1.6$ & $<2.6$ & $<0.87$ & $<0.046$ & $<9.0$ & {$[22]$} & {$[0.21]$} & $<2.5$ & $<0.034$ & {$[2.7]$} & $<0.12$ \\
\hline AFA-Test 10-CLI-M & $(\mu \mathrm{g} / \mathrm{mL})$ & {$[0.02]$} & $<1.6$ & $<2.6$ & $<0.87$ & {$[0.06]$} & $<9.0$ & {$[24]$} & {$[0.08]$} & $<2.5$ & $<0.034$ & {$[2.5]$} & {$[0.14]$} \\
\hline
\end{tabular}

(a) Values in brackets [] are $\geq$ the method detection limit, but are $<$ the estimated quantitation limit, with errors likely to exceed $15 \%$. 
Table B.3. Metals Analysis for Initial Equilibrated Simulated Tank Waste Solids ${ }^{(a)}$

\begin{tabular}{|c|c|c|c|c|c|c|c|c|c|c|c|}
\hline Sample Number & (Analyte) & $\mathrm{Al}$ & $\mathrm{Cr}$ & $\mathrm{Fe}$ & $\mathrm{P}$ & $\mathrm{Si}$ & $\mathrm{Ag}$ & As & $\mathrm{B}$ & $\mathrm{Ba}$ & $\mathrm{Be}$ \\
\hline AFA-Test-1-CLI-S & $(\mu \mathrm{g} / \mathrm{g})$ & $<3,900$ & 120,000 & 160,000 & $<730$ & {$[23,000]$} & $<20$ & $<1,800$ & 1,900 & 880 & $<0.65$ \\
\hline AFA-Test-2-CLI-S & $(\mu \mathrm{g} / \mathrm{g})$ & $<2,600$ & 79,000 & 110,000 & $<480$ & 40,000 & $<13$ & $<1,200$ & 3,700 & 640 & $<0.43$ \\
\hline AFA-Test-3-CLI-S & $(\mu \mathrm{g} / \mathrm{g})$ & $<3,500$ & 110,000 & 150,000 & $<660$ & {$[25,000]$} & $<18$ & $<1,600$ & 2,200 & 820 & $<0.58$ \\
\hline AFA-Test-4a-CLI-S & $(\mu \mathrm{g} / \mathrm{g})$ & $<3,400$ & 110,000 & 140,000 & $<630$ & 29,000 & $<18$ & $<1,500$ & 2,400 & 810 & $<0.56$ \\
\hline AFA-Test-4b-CLI-S & $(\mu \mathrm{g} / \mathrm{g})$ & $<3,800$ & 120,000 & 160,000 & $<710$ & {$[26,000]$} & $<20$ & $<1,700$ & 2,200 & 890 & $<0.63$ \\
\hline AFA-Test-4c-CLI-S & $(\mu \mathrm{g} / \mathrm{g})$ & $<3,200$ & 97,000 & 140,000 & $<590$ & {$[14,000]$} & $<17$ & $<1,400$ & 1,200 & 710 & $<0.53$ \\
\hline AFA-Test-5-CLI-S & $(\mu \mathrm{g} / \mathrm{g})$ & $<3,500$ & 100,000 & 150,000 & $<650$ & {$[13,000]$} & $<18$ & $<1,600$ & 1,100 & 780 & $<0.58$ \\
\hline AFA-Test-6-CLI-S & $(\mu \mathrm{g} / \mathrm{g})$ & $<3,400$ & 100,000 & 140,000 & $<630$ & {$[4,900]$} & $<17$ & $<1,500$ & {$[420]$} & 800 & $<0.56$ \\
\hline AFA-Test-7-CLI-S & $(\mu \mathrm{g} / \mathrm{g})$ & $<3,100$ & 92,000 & 120,000 & $<580$ & {$[16,000]$} & $<16$ & $<1,400$ & 1,400 & 730 & $<0.52$ \\
\hline AFA-Test-8a-CLI-S & $(\mu \mathrm{g} / \mathrm{g})$ & $<3,100$ & 86,000 & 110,000 & $<570$ & {$[19,000]$} & $<16$ & $<1,400$ & 1,700 & 680 & $<0.51$ \\
\hline AFA-Test-8b-CLI-S & $(\mu \mathrm{g} / \mathrm{g})$ & $<2,900$ & 88,000 & 120,000 & $<540$ & {$[15,000]$} & $<15$ & $<1,300$ & 1,300 & 690 & $<0.48$ \\
\hline AFA-Test-8c-CLI-S & $(\mu \mathrm{g} / \mathrm{g})$ & $<2,000$ & 57,000 & 76,000 & $<370$ & 17,000 & $<10$ & $<890$ & 1,600 & 450 & $<0.33$ \\
\hline AFA-Test-9-CLI-S & $(\mu \mathrm{g} / \mathrm{g})$ & $<2,600$ & 110,000 & 150,000 & $<480$ & {$[6,900]$} & $<13$ & $<1,200$ & {$[680]$} & 880 & $<0.43$ \\
\hline AFA-Test-10-CLI-S & $(\mu \mathrm{g} / \mathrm{g})$ & $<1,900$ & 99,000 & 130,000 & $<350$ & {$[13,000]$} & $<10$ & $<850$ & 1,300 & 770 & {$[0.58]$} \\
\hline
\end{tabular}

(a) Values in brackets [] are $\geq$ the method detection limit, but are $<$ the estimated quantitation limit, with errors likely to exceed $15 \%$. 
Table B.3 (contd) $)^{(a)}$

\begin{tabular}{|c|c|c|c|c|c|c|c|c|c|c|c|c|c|}
\hline & (Analyte) & $\mathrm{Bi}$ & $\mathrm{Ca}$ & $\mathrm{Cd}$ & $\mathrm{Ce}$ & $\mathrm{Co}$ & $\mathrm{Cu}$ & Dy & $\mathrm{Eu}$ & $\mathrm{K}$ & $\mathrm{La}$ & $\mathrm{Li}$ & $\mathrm{Mg}$ \\
\hline AFA-Test 1-CLI-S & $(\mu \mathrm{g} / \mathrm{g})$ & $<320$ & $<15,000$ & $<20$ & {$[160]$} & $<36$ & {$[77]$} & $<39$ & $<5$ & na & {$[62]$} & [32] & [220] \\
\hline AFA-Test 2-CLI-S & $(\mu \mathrm{g} / \mathrm{g})$ & $<220$ & $<9,900$ & $<13$ & {$[160]$} & [34] & {$[160]$} & $<26$ & $<3$ & na & [130] & [21] & [190] \\
\hline AFA-Test 3-CLI-S & $(\mu \mathrm{g} / \mathrm{g})$ & $<290$ & $<13,000$ & $<18$ & [290] & $<33$ & [92] & $<35$ & $<5$ & na & [64] & [24] & [160] \\
\hline AFA-Test 4a-CLI-S & $(\mu \mathrm{g} / \mathrm{g})$ & $<280$ & $<13,000$ & {$[18]$} & {$[120]$} & {$[36]$} & 270 & $<34$ & $<4$ & na & [93] & $<22$ & [170] \\
\hline AFA-Test 4b-CLI-S & $(\mu \mathrm{g} / \mathrm{g})$ & $<310$ & $<14,000$ & $<20$ & {$[150]$} & $<35$ & {$[80]$} & $<38$ & $<5$ & na & [65] & [32] & [190] \\
\hline AFA-Test 4c-CLI-S & $(\mu \mathrm{g} / \mathrm{g})$ & $<260$ & $<12,000$ & $<17$ & {$[150]$} & {$[65]$} & {$[66]$} & $<32$ & $<4$ & na & $<30$ & [21] & [220] \\
\hline AFA-Test 5-CLI-S & $(\mu \mathrm{g} / \mathrm{g})$ & $<290$ & $<13,000$ & $<18$ & [230] & [71] & 2,300 & $<35$ & $<5$ & na & {$[80]$} & $<23$ & [390] \\
\hline AFA-Test 6-CLI-S & $(\mu \mathrm{g} / \mathrm{g})$ & $<280$ & $<13,000$ & $<17$ & {$[260]$} & $<31$ & [89] & $<34$ & $<4$ & na & {$[120]$} & [24] & [110] \\
\hline AFA-Test 7-CLI-S & $(\mu \mathrm{g} / \mathrm{g})$ & $<260$ & $<12,000$ & $<16$ & $<90$ & $<29$ & {$[53]$} & $<31$ & $<4$ & na & {$[56]$} & {$[27]$} & [140] \\
\hline AFA-Test 8a-CLI-S & $(\mu \mathrm{g} / \mathrm{g})$ & $<250$ & $<12,000$ & $<16$ & $<88$ & $<29$ & {$[26]$} & $<31$ & $<4$ & na & [29] & $<20$ & [140] \\
\hline AFA-Test 8b-CLI-S & $(\mu \mathrm{g} / \mathrm{g})$ & $<240$ & $<11,000$ & $<15$ & $<83$ & $<27$ & $<20.00$ & $<29$ & $<4$ & na & [33] & $<19$ & [110] \\
\hline AFA-Test 8c-CLI-S & $(\mu \mathrm{g} / \mathrm{g})$ & $<160$ & $<7,500$ & $<10$ & $<57$ & {$[25]$} & {$[66]$} & $<20$ & $<3$ & na & $<18$ & $<13$ & [100] \\
\hline AFA-Test 9-CLI-S & $(\mu \mathrm{g} / \mathrm{g})$ & $<210$ & $<9,800$ & $<13$ & {$[92]$} & $<24$ & {$[52]$} & $<26$ & $<3$ & na & {$[32]$} & $<17$ & {$[75]$} \\
\hline AFA-Test 10-CLI-S & $(\mu \mathrm{g} / \mathrm{g})$ & $<160$ & $<7,200$ & $<10$ & {$[86]$} & [27] & [31] & $<19$ & $<2$ & na & {$[34]$} & [14] & [95] \\
\hline
\end{tabular}

(a) Values in brackets [] are $\geq$ the method detection limit, but are $<$ the estimated quantitation limit, with errors likely to exceed $15 \%$. 
Table B.3 (contd) $)^{(\mathrm{a})}$

\begin{tabular}{|c|c|c|c|c|c|c|c|c|c|c|c|c|}
\hline & (Analyte) & $\mathrm{Mn}$ & Mo & $\mathrm{Na}$ & $\mathrm{Nd}$ & $\mathrm{Ni}$ & $\mathrm{Pb}$ & $\mathrm{Pd}$ & $\mathrm{Rh}$ & $\mathrm{Ru}$ & $\mathrm{S}$ & $\mathrm{Sb}$ \\
\hline AFA-Test 1-CLI-S & $(\mu \mathrm{g} / \mathrm{g})$ & 240 & $<97$ & {$[170,000]$} & [240] & na & $<430$ & $<86$ & $<180$ & $<90$ & $<4,400$ & $<420$ \\
\hline AFA-Test 2-CLI-S & $(\mu \mathrm{g} / \mathrm{g})$ & 170 & $<65$ & 240,000 & [210] & na & $<290$ & $<57$ & $<120$ & $<60$ & $<3,000$ & $<280$ \\
\hline AFA-Test 3-CLI-S & $(\mu \mathrm{g} / \mathrm{g})$ & 180 & $<87$ & {$[200,000]$} & {$[240]$} & na & $<390$ & $<78$ & $<160$ & $<81$ & $<4,000$ & $<380$ \\
\hline AFA-Test 4a-CLI-S & $(\mu \mathrm{g} / \mathrm{g})$ & 370 & $<84$ & {$[200,000]$} & {$[250]$} & na & $<370$ & $<75$ & $<150$ & $<78$ & $<3,900$ & $<360$ \\
\hline AFA-Test 4b-CLI-S & $(\mu \mathrm{g} / \mathrm{g})$ & 300 & $<94$ & {$[190,000]$} & [110] & na & $<420$ & $<84$ & $<170$ & $<88$ & $<4,300$ & $<410$ \\
\hline AFA-Test 4c-CLI-S & $(\mu \mathrm{g} / \mathrm{g})$ & 160 & $<79$ & {$[200,000]$} & {$[170]$} & na & $<350$ & $<70$ & $<140$ & $<74$ & $<3,600$ & $<340$ \\
\hline AFA-Test 5-CLI-S & $(\mu \mathrm{g} / \mathrm{g})$ & 640 & $<87$ & {$[180,000]$} & {$[240]$} & na & $<390$ & $<77$ & $<160$ & $<81$ & $<4,000$ & $<380$ \\
\hline AFA-Test 6-CLI-S & $(\mu \mathrm{g} / \mathrm{g})$ & [76] & $<84$ & {$[180,000]$} & [230] & na & $<370$ & $<74$ & $<150$ & $<78$ & $<3,800$ & $<360$ \\
\hline AFA-Test 7-CLI-S & $(\mu \mathrm{g} / \mathrm{g})$ & {$[62]$} & $<78$ & 210,000 & {$[120]$} & na & $<350$ & $<69$ & $<140$ & $<73$ & $<3,600$ & $<340$ \\
\hline AFA-Test 8a-CLI-S & $(\mu \mathrm{g} / \mathrm{g})$ & {$[36]$} & $<76$ & {$[200,000]$} & {$[78]$} & na & $<340$ & $<68$ & $<140$ & $<71$ & $<3,500$ & $<330$ \\
\hline AFA-Test 8b-CLI-S & $(\mu \mathrm{g} / \mathrm{g})$ & {$[11]$} & $<72$ & 210,000 & $<64$ & na & $<320$ & $<64$ & $<130$ & $<67$ & $<3,300$ & $<310$ \\
\hline AFA-Test 8c-CLI-S & $(\mu \mathrm{g} / \mathrm{g})$ & $<7.50$ & $<49$ & 270,000 & $<44$ & na & $<220$ & $<44$ & $<89$ & $<46$ & $<2,300$ & $<210$ \\
\hline AFA-Test 9-CLI-S & $(\mu \mathrm{g} / \mathrm{g})$ & $<9.80$ & $<64$ & {$[160,000]$} & $<57$ & na & $<290$ & $<57$ & $<120$ & $<60$ & $<3,000$ & $<280$ \\
\hline AFA-Test 10-CLI-S & $(\mu \mathrm{g} / \mathrm{g})$ & $<7.20$ & $<47$ & 180,000 & [87] & na & $<210$ & $<42$ & $<85$ & $<44$ & $<2,100$ & $<200$ \\
\hline
\end{tabular}

(a) Values in brackets [] are $\geq$ the method detection limit, but are $<$ the estimated quantitation limit, with errors likely to exceed $15 \%$. 
Table B.3 (contd) $)^{(\mathrm{a})}$

\begin{tabular}{|c|c|c|c|c|c|c|c|c|c|c|c|c|}
\hline & (Analyte) & $\mathrm{Se}$ & $\mathrm{Sn}$ & $\mathrm{Sr}$ & $\mathrm{Ta}$ & $\mathrm{Te}$ & Th & $\mathrm{Ti}$ & $\mathrm{Tl}$ & $\mathrm{U}$ & $\mathrm{V}$ & $\mathrm{W}$ \\
\hline AFA-Test 1-CLI-S & $(\mu \mathrm{g} / \mathrm{g})$ & $<1,300$ & $<290$ & $<3$ & $<230$ & $<300$ & $<97$ & [29] & $<350$ & $<480$ & $<37$ & $<280$ \\
\hline AFA-Test 2-CLI-S & $(\mu \mathrm{g} / \mathrm{g})$ & $<980$ & $<220$ & $<2$ & $<180$ & $<230$ & $<75$ & $<5$ & $<270$ & $<370$ & $<29$ & $<210$ \\
\hline AFA-Test 3-CLI-S & $(\mu \mathrm{g} / \mathrm{g})$ & $<1,500$ & $<340$ & 1,700 & $<270$ & $<350$ & $<110$ & {$[11]$} & $<400$ & {$[2,800]$} & $<43$ & $<320$ \\
\hline AFA-Test 4a-CLI-S & $(\mu \mathrm{g} / \mathrm{g})$ & $<990$ & $<220$ & 1,100 & $<180$ & $<230$ & $<75$ & {$[11]$} & $<270$ & {$[2,000]$} & $<29$ & $<220$ \\
\hline AFA-Test 4b-CLI-S & $(\mu \mathrm{g} / \mathrm{g})$ & $<1,300$ & $<300$ & 1,500 & $<240$ & $<320$ & $<100$ & {$[13]$} & $<360$ & {$[1,200]$} & $<39$ & $<290$ \\
\hline AFA-Test 4c-CLI-S & $(\mu \mathrm{g} / \mathrm{g})$ & $<1,300$ & $<290$ & 1,500 & $<230$ & $<300$ & $<98$ & {$[12]$} & $<350$ & {$[2,500]$} & $<37$ & $<280$ \\
\hline AFA-Test 5-CLI-S & $(\mu \mathrm{g} / \mathrm{g})$ & $<1,400$ & $<330$ & 1,700 & $<260$ & $<340$ & $<110$ & $<7$ & $<390$ & {$[2,900]$} & $<42$ & $<310$ \\
\hline AFA-Test 6-CLI-S & $(\mu \mathrm{g} / \mathrm{g})$ & $<1,200$ & $<280$ & 1,400 & $<220$ & $<290$ & $<93$ & [8.1] & $<330$ & {$[1,700]$} & $<35$ & $<260$ \\
\hline AFA-Test 7-CLI-S & $(\mu \mathrm{g} / \mathrm{g})$ & $<1,300$ & $<300$ & 1,500 & $<240$ & $<310$ & $<100$ & {$[16]$} & {$[390]$} & {$[2,800]$} & $<39$ & $<290$ \\
\hline AFA-Test 8a-CLI-S & $(\mu \mathrm{g} / \mathrm{g})$ & $<1,300$ & $<290$ & 1,500 & $<230$ & $<300$ & $<98$ & $<6$ & $<350$ & {$[3,500]$} & $<37$ & $<280$ \\
\hline AFA-Test 8b-CLI-S & $(\mu \mathrm{g} / \mathrm{g})$ & $<1,200$ & $<270$ & 1,300 & $<220$ & $<280$ & $<91$ & $<6$ & $<320$ & {$[1,900]$} & $<35$ & $<260$ \\
\hline AFA-Test 8c-CLI-S & $(\mu \mathrm{g} / \mathrm{g})$ & $<1,200$ & $<260$ & 1,200 & $<210$ & $<270$ & $<89$ & $<5$ & [320] & {$[2,800]$} & $<34$ & $<250$ \\
\hline AFA-Test 9-CLI-S & $(\mu \mathrm{g} / \mathrm{g})$ & $<1,100$ & $<250$ & 1,300 & $<200$ & $<260$ & $<84$ & $<5$ & $<300$ & {$[3,400]$} & $<32$ & $<240$ \\
\hline AFA-Test 10-CLI-S & $(\mu \mathrm{g} / \mathrm{g})$ & $<750$ & $<170$ & 810 & $<140$ & $<180$ & $<58$ & [8.7] & $<210$ & {$[1,900]$} & $<22$ & $<160$ \\
\hline
\end{tabular}

(a) Values in brackets [] are $\geq$ the method detection limit, but are $<$ the estimated quantitation limit, with errors likely to exceed $15 \%$. 
Table B.3 (contd) ${ }^{(\mathrm{a})}$

\begin{tabular}{lcccc}
\hline & $($ Analyte $)$ & $\mathrm{Y}$ & $\mathrm{Zn}$ & $\mathrm{Zr}$ \\
\hline AFA-Test 1-CLI-S & $(\mu \mathrm{g} / \mathrm{g})$ & $<3$ & 1,200 & $<19$ \\
AFA-Test 2-CLI-S & $(\mu \mathrm{g} / \mathrm{g})$ & $<3$ & {$[150]$} & $<14$ \\
AFA-Test 3-CLI-S & $(\mu \mathrm{g} / \mathrm{g})$ & $<4$ & 1,400 & 330 \\
AFA-Test 4a-CLI-S & $(\mu \mathrm{g} / \mathrm{g})$ & $<3$ & 1,100 & 420 \\
AFA-Test 4b-CLI-S & $(\mu \mathrm{g} / \mathrm{g})$ & $<4$ & 1,400 & 310 \\
AFA-Test 4c-CLI-S & $(\mu \mathrm{g} / \mathrm{g})$ & $<3$ & 1,400 & 370 \\
AFA-Test 5-CLI-S & $(\mu \mathrm{g} / \mathrm{g})$ & $<4$ & 1,500 & 410 \\
AFA-Test 6-CLI-S & $(\mu \mathrm{g} / \mathrm{g})$ & $<3$ & 1,200 & 220 \\
AFA-Test 7-CLI-S & $(\mu \mathrm{g} / \mathrm{g})$ & $<4$ & 2,600 & 250 \\
AFA-Test 8a-CLI-S & $(\mu \mathrm{g} / \mathrm{g})$ & $<3$ & 1,200 & 840 \\
AFA-Test 8b-CLI-S & $(\mu \mathrm{g} / \mathrm{g})$ & $<3$ & 1,100 & {$[150]$} \\
AFA-Test 8c-CLI-S & $(\mu \mathrm{g} / \mathrm{g})$ & $<3$ & 960 & {$[130]$} \\
AFA-Test 9-CLI-S & $(\mu \mathrm{g} / \mathrm{g})$ & $<3$ & 1,200 & {$[80]$} \\
AFA-Test 10-CLI-S & $(\mu \mathrm{g} / \mathrm{g})$ & $<2$ & 700 & {$[39]$} \\
\hline
\end{tabular}

(a) Values in brackets [] are $\geq$ the method detection limit, but are $<$ the estimated quantitation limit, with errors likely to exceed $15 \%$. 
Table B.4. Measured Nonradioactive Component Concentrations for Combined Leachate \& Wash Solutions

\begin{tabular}{|c|c|c|c|c|c|c|c|c|c|c|}
\hline \multirow[t]{2}{*}{ Test } & \multicolumn{2}{|c|}{$\begin{array}{c}\mathrm{Cr} \\
(\mu \mathrm{g} / \mathrm{mL})\end{array}$} & \multicolumn{2}{|c|}{$\begin{array}{c}\text { Fe } \\
(\mu \mathrm{g} / \mathrm{mL})\end{array}$} & \multicolumn{2}{|c|}{$\begin{array}{c}\mathrm{Mn} \\
(\mu \mathrm{g} / \mathrm{mL})\end{array}$} & \multicolumn{2}{|c|}{$\begin{array}{c}\mathrm{Ni} \\
(\mu \mathrm{g} / \mathrm{mL})\end{array}$} & \multicolumn{2}{|c|}{$\begin{array}{c}\mathrm{U} \\
(\mu \mathrm{g} / \mathrm{mL})\end{array}$} \\
\hline & CL & OL & $\mathrm{CL}$ & OL & CL & $\mathrm{OL}$ & CL & OL & CL & OL \\
\hline 1 & 18.4 & 2,020 & {$[0.66]$} & 0.18 & $<0.02$ & $<0.04$ & $<0.51$ & $<0.03$ & [13] & {$[1.80]$} \\
\hline 2 & 19.4 & 1,960 & {$[0.33]$} & 0.22 & $<0.02$ & $<0.04$ & $<0.51$ & $<0.03$ & [14] & 6.46 \\
\hline 3 & 20.1 & 2,010 & {$[0.33]$} & 0.26 & $<0.02$ & $<0.04$ & $<0.51$ & $<0.03$ & [18] & 6.48 \\
\hline $4 a$ & 13.5 & 2,010 & {$[0.18]$} & 0.18 & $<0.02$ & $<0.04$ & $<0.51$ & $<0.03$ & [16] & 2.65 \\
\hline $4 b$ & 13.6 & 1,910 & {$[0.23]$} & {$[0.16]$} & $<0.02$ & $<0.04$ & $<0.51$ & $<0.03$ & [13] & 2.35 \\
\hline $4 c$ & 16.6 & 2,250 & {$[0.25]$} & [0.095] & $<0.02$ & $<0.04$ & $<0.51$ & $<0.03$ & [17] & 5.44 \\
\hline 5 & 17.6 & 2,070 & {$[0.31]$} & 0.24 & $<0.02$ & 4.53 & $<0.51$ & $<0.03$ & [14] & 3.32 \\
\hline 6 & 17.6 & 2,030 & {$[0.27]$} & [0.11] & $<0.02$ & $<0.04$ & $<0.51$ & $<0.03$ & [14] & 3.34 \\
\hline 7 & 12.7 & 2,000 & {$[0.24]$} & {$[0.11]$} & $<0.02$ & $<0.04$ & $<0.51$ & $<0.03$ & [17] & 6.59 \\
\hline $8 a$ & 12.9 & 2,260 & {$[0.33]$} & {$[0.14]$} & $<0.02$ & $<0.04$ & $<0.51$ & $<0.03$ & [16] & 4.17 \\
\hline $8 b$ & 17.1 & 2,330 & {$[0.24]$} & {$[0.13]$} & $<0.02$ & $<0.04$ & $<0.51$ & $<0.03$ & [24] & {$[2.00]$} \\
\hline $8 \mathrm{c}$ & 17.1 & 2,070 & $<0.100$ & {$[0.11]$} & $<0.02$ & 15.50 & $<0.51$ & $<0.03$ & [13] & {$[1.70]$} \\
\hline 9 & 20.3 & 2,010 & {$[0.39]$} & 0.73 & $<0.02$ & $<0.01$ & $<0.51$ & $<0.03$ & [17] & [1.90] \\
\hline 10 & 12.0 & 2,240 & {$[0.25]$} & {$[0.13]$} & $<0.02$ & $<10.10$ & $<0.51$ & $<0.03$ & {$[16]$} & {$[2.00]$} \\
\hline
\end{tabular}


Table B.5. Measured Radioactive Component Concentrations for Combined Leachate \& Wash Solutions

\begin{tabular}{|c|c|c|c|c|}
\hline & \multicolumn{2}{|c|}{$\begin{array}{l}{ }^{239+240} \mathrm{Pu} \\
(\mu \mathrm{Ci} / \mathrm{mL})\end{array}$} & \multicolumn{2}{|c|}{$\begin{array}{c}{ }^{238} \mathrm{Pu}+{ }^{241} \mathrm{Am} \\
(\mu \mathrm{Ci} / \mathrm{mL})\end{array}$} \\
\hline & CL & $\mathrm{OL}$ & CL & $\mathrm{OL}$ \\
\hline & $1.47 \mathrm{E}-05$ & $6.06 \mathrm{E}-05$ & 4.38E-07 & $1.33 \mathrm{E}-06$ \\
\hline & $1.50 \mathrm{E}-05$ & $4.20 \mathrm{E}-05$ & $<4$.E-07 & 8.51E-07 \\
\hline & $2.35 \mathrm{E}-05$ & $2.96 \mathrm{E}-05$ & $4.42 \mathrm{E}-07$ & $6.14 \mathrm{E}-07$ \\
\hline & $2.21 \mathrm{E}-05$ & $2.36 \mathrm{E}-05$ & $5.07 \mathrm{E}-07$ & $<5$. E-07 \\
\hline & $1.91 \mathrm{E}-05$ & $1.11 \mathrm{E}-05$ & $<5$. E-07 & $<6 . \mathrm{E}-07$ \\
\hline & $2.76 \mathrm{E}-05$ & $5.01 \mathrm{E}-06$ & $<4 . \mathrm{E}-07$ & $<2 . \mathrm{E}-07$ \\
\hline \multirow{9}{*}{$\underset{⿱ 亠 凶}{\tilde{N}}$} & $1.43 \mathrm{E}-05$ & $6.11 \mathrm{E}-04$ & $<5$. E-07 & $1.18 \mathrm{E}-05$ \\
\hline & $1.46 \mathrm{E}-05$ & 7.17E-06 & $3.27 \mathrm{E}-07$ & $<2 . \mathrm{E}-07$ \\
\hline & $2.90 \mathrm{E}-05$ & $4.01 \mathrm{E}-04$ & $4.51 \mathrm{E}-07$ & $7.11 \mathrm{E}-06$ \\
\hline & $2.42 \mathrm{E}-05$ & $2.32 \mathrm{E}-06$ & 4.74E-07 & $<2 . \mathrm{E}-07$ \\
\hline & $1.94 \mathrm{E}-05$ & $1.13 \mathrm{E}-06$ & $2.81 \mathrm{E}-07$ & $<2 . \mathrm{E}-07$ \\
\hline & $1.41 \mathrm{E}-05$ & 8.72E-05 & $2.45 \mathrm{E}-07$ & $1.54 \mathrm{E}-06$ \\
\hline & $1.64 \mathrm{E}-05$ & $1.27 \mathrm{E}-06$ & $2.88 \mathrm{E}-07$ & $<1 . \mathrm{E}-07$ \\
\hline & $4.46 \mathrm{E}-05$ & $8.59 \mathrm{E}-05$ & 7.39E-07 & $1.65 \mathrm{E}-06$ \\
\hline & & $\mathrm{L}=$ Causti & ive Leachat & \\
\hline
\end{tabular}


Table B.6. Residual Solids Mass and Component Concentrations

\begin{tabular}{|c|c|c|c|c|c|c|c|c|c|}
\hline Test & $\begin{array}{l}\text { Residual } \\
\text { Mass (g) }\end{array}$ & $\mathrm{Cr}(\mu \mathrm{g} / \mathrm{g})$ & $\mathrm{Fe}(\mu \mathrm{g} / \mathrm{g})$ & $\mathrm{Mn}(\mu \mathrm{g} / \mathrm{g})$ & $\mathrm{Ni}(\mu \mathrm{g} / \mathrm{g})$ & $\mathrm{U}(\mu \mathrm{g} / \mathrm{g})$ & $\mathrm{Zn}(\mu \mathrm{g} / \mathrm{g})$ & $\begin{array}{c}{ }^{239+240} \mathrm{Pu}, \\
\text { from } \mathrm{AEA} \text {, } \\
\quad \mu \mathrm{Ci} / \mathrm{g}\end{array}$ & $\begin{array}{c}{ }^{238} \mathrm{Pu}^{241} \mathrm{Am}, \\
\text { from } \mathrm{AEA} \\
\mu \mathrm{Ci} / \mathrm{g}\end{array}$ \\
\hline 1 & 3.067 & 29,400 & 257,000 & 184,000 & NA & 14,900 & 1,860 & 19.7 & $5.93 \mathrm{E}-01$ \\
\hline 2 & 3.005 & 37,200 & 226,000 & 166,000 & NA & 14,600 & 1,600 & 20.7 & $5.48 \mathrm{E}-01$ \\
\hline 3 & 3.038 & 21,500 & 251,000 & 186,000 & NA & 14,200 & 1,830 & 21.4 & $5.84 \mathrm{E}-01$ \\
\hline $4 a$ & 3.001 & 22,500 & 275,000 & 208,000 & NA & 19,700 & 2,090 & 20.8 & $5.90 \mathrm{E}-01$ \\
\hline $4 \mathrm{~b}$ & 3.044 & 26,700 & 243,000 & 183,000 & NA & 14,000 & 1,710 & 22.9 & $6.14 \mathrm{E}-01$ \\
\hline $4 c$ & 3.016 & 8,750 & 253,000 & 195,000 & NA & 32,000 & 1,860 & 24.4 & $6.39 \mathrm{E}-01$ \\
\hline 5 & 3.015 & 6,300 & 262,000 & 203,000 & NA & 13,900 & 1,950 & 24.8 & $6.38 \mathrm{E}-01$ \\
\hline 6 & 2.979 & 8,010 & 236,000 & 200,000 & NA & 33,300 & 2,020 & 24.4 & $5.65 \mathrm{E}-01$ \\
\hline 7 & 3.086 & 8,730 & 246,000 & 196,000 & NA & 23,100 & 1,990 & 25.1 & $6.25 \mathrm{E}-01$ \\
\hline $8 a$ & 3.002 & 7,830 & 250,000 & 197,000 & NA & 23,900 & 1,960 & 23.2 & $5.78 \mathrm{E}-01$ \\
\hline $8 b$ & 3.070 & 8,810 & 253,000 & 195,000 & NA & 23,000 & 1,980 & 23.3 & $5.84 \mathrm{E}-01$ \\
\hline $8 \mathrm{c}$ & 3.019 & 7,220 & 197,000 & 216,000 & NA & 36,700 & 1,670 & 22.4 & $6.01 \mathrm{E}-01$ \\
\hline 9 & 3.086 & 10,000 & 264,000 & 197,000 & NA & 13,500 & 2,220 & 24.0 & $6.27 \mathrm{E}-01$ \\
\hline 10 & 3.063 & 6,740 & 245,000 & 192,000 & NA & 28,400 & 2,370 & 23.9 & $5.78 \mathrm{E}-01$ \\
\hline
\end{tabular}



PNNL-19015

WTP-RPT-206, Rev 0

\section{Distribution}

No. of

Copies

ONSITE

Pacific Northwest National Laboratory (authors will be notified electronically)

B.M. Rapko

P7-25

S.A. Jones

$\mathrm{P} 7-25$

D.E. Kurath

K3-52

G.J. Lumetta

P7-25

R.A. Peterson

$\mathrm{P} 7-22$

Information Release (pdf)

2 Bechtel National Incorporated

WTP R\&T Docs

H4-02

P.S. Sundar

H4-02

Distr. 1 


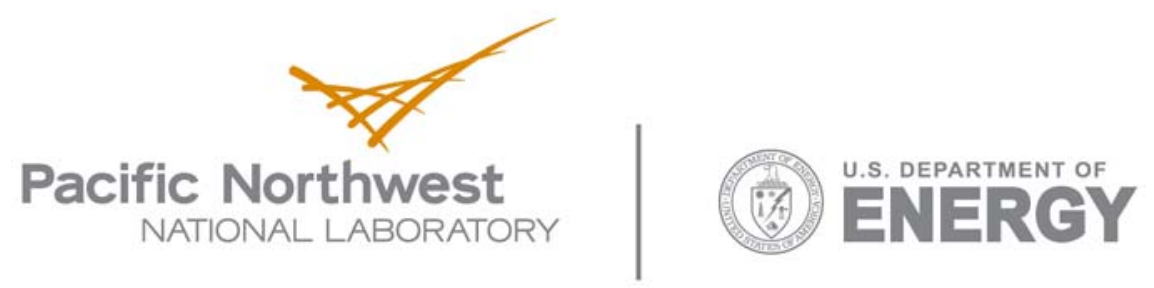

902 Battelle Boulevard

P.O. Box 999

Richland, WA 99352

1-888-375-PNNL (7665)

www.pnl.gov 